15

c. 3

my Corps

of Engineers

Waterways Experiment

Station

\title{
Rubble-Mound Breakwater Stability Tests for Dos Bocas Harbor, Tabasco, Mexico
}

by Robert D. Carver 
The contents of this report are not to be used for advertising, publication, or promotional purposes. Citation of trade names does not constitute an official endorsement or approval of the use of such commercial products.

The findings of this report are not to be construed as an official Department of the Army position, unless so designated by other authorized documents.

9 PRINTED on RECYCLED PAPER

USACEWES 


\title{
Rubble-Mound Breakwater Stability Tests for Dos Bocas Harbor, Tabasco, Mexico
}

by Robert D. Carver

U.S. Army Corps of Engineers

Waterways Experiment Station

3909 Halls Ferry Road

Vicksburg, MS 39180-6199

Final report

Approved for public release; distribution is unlimited

\author{
Prepared for Preinversion and Desarrollo, S.A. de C.V. \\ Callejon Retama 30, D. F. 04010, Mexico \\ and PEMEX Refinación y Producción \\ Marino Nacional \#329, C. P. 11311, Mexico
}




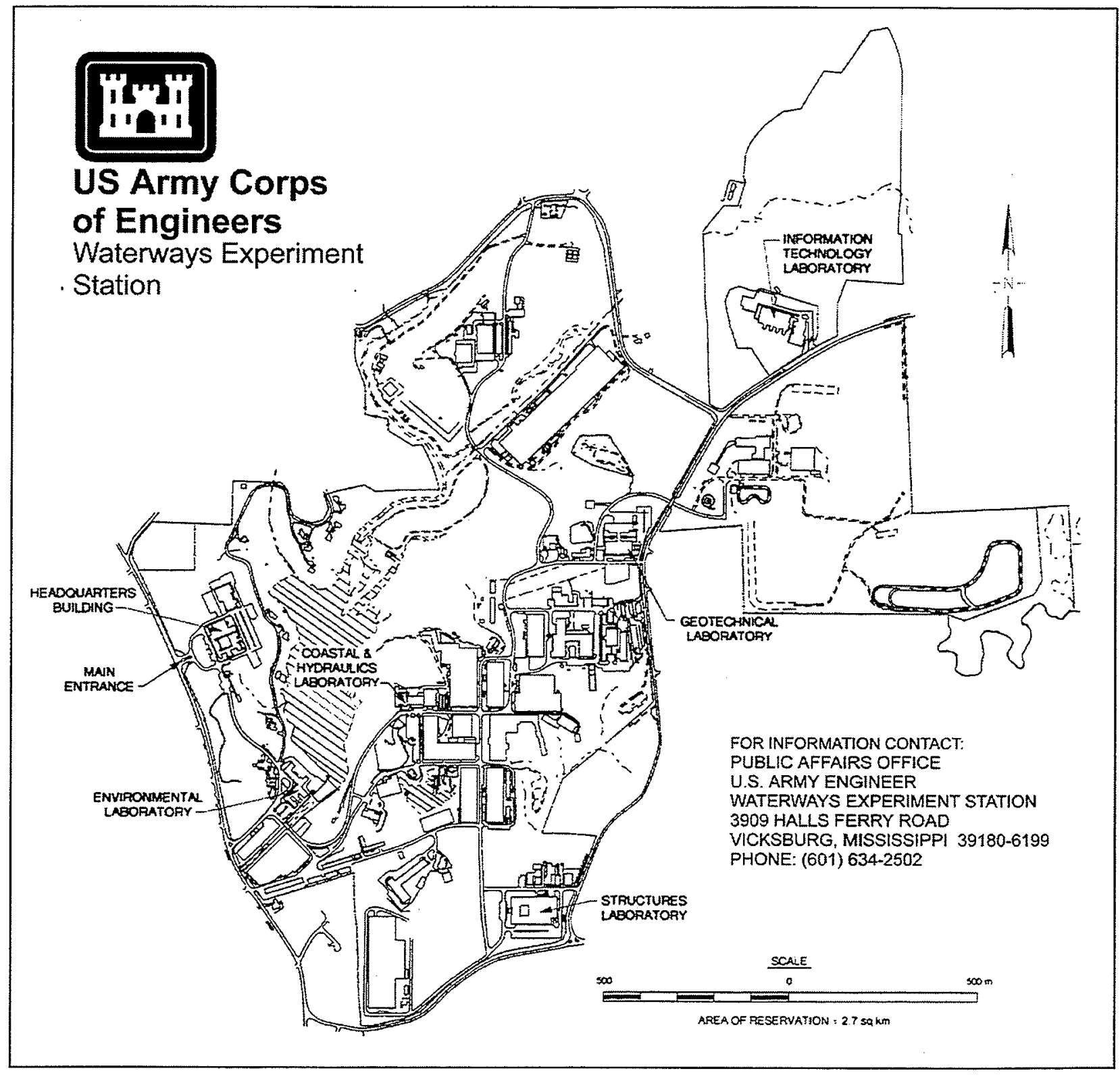

\section{Waterways Experiment Station Cataloging-in-Publication Data}

Carver, Robert D.

Rubble-mound breakwater stability tests for Dos Bocas Harbor, Tabasco, Mexico / by Robert D. Carver ; prepared for Preinversion and Desarrollo, S.A. de C.V. and PEMEX Refinacion y Produccion.

121 p. : ill. ; $28 \mathrm{~cm}$. -- (Technical report ; CHL-99-15)

Includes bibliographic references.

1. Rubble mound breakwaters -- Stability. 2. Harbors -- Mexico -- Tabasco (State) 3. Dos Bocas Harbor (Mexico) 1. United States. Army. Corps of Engineers. II. U.S. Army Engineer Waterways Experiment Station. III. Coastal and Hydraulics Laboratory (U.S. Army Engineer Watenways Experiment Station) IV. Preinversion and Desarrollo (Mexico) V. Petrâoleos Mexicanos. VI. Title. VII. Series: Technical report (U.S. Army Engineer Waterways Experiment Station) ; CHL-99-15.

TA7 W34 no.CHL-99-15 


\section{Contents}

Preface................................ iv

Conversion Factors, SI to Non-SI Units of Measurement.... . v

1 -Introduction............................. 1

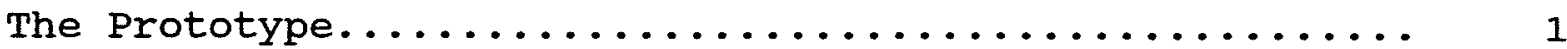

Purpose of Model Investigation.................... 1

2 -The Model................................ 2

Model-Prototype Scale Relationships................ 2

Test Equipment and Facilities................... 3

3-stability Tests and Results..................... 4

Method of Constructing Test sections............... 4

Description of Plan $1 \ldots \ldots \ldots \ldots \ldots \ldots \ldots \ldots \ldots \ldots \ldots \ldots$

Selection of Test Conditions.................... 4

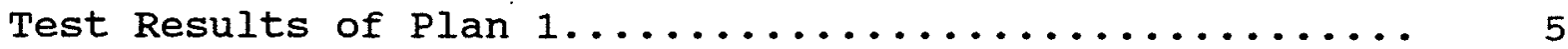

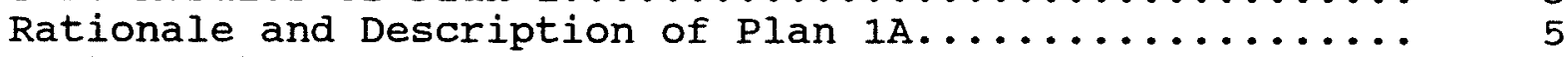

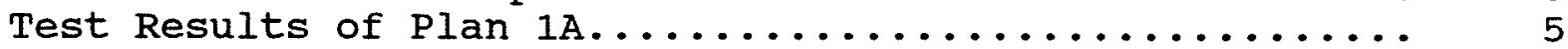

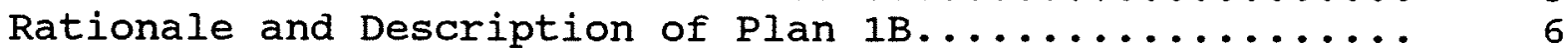

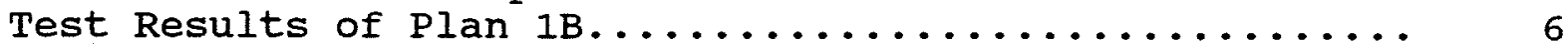

Rationale and Description of Plan 1C............... 6

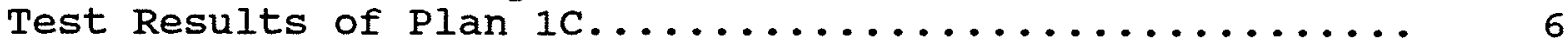

Discussion of Plans $1,1 \mathrm{~A}, 1 \mathrm{~B}$ and $1 \mathrm{C}$ Test Results...... 7

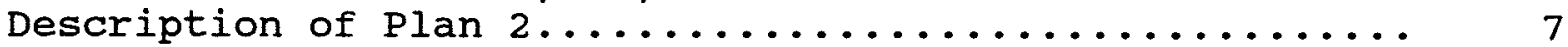

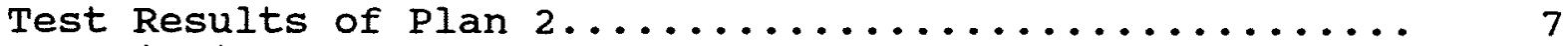

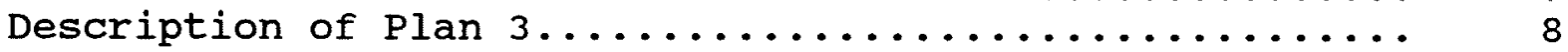

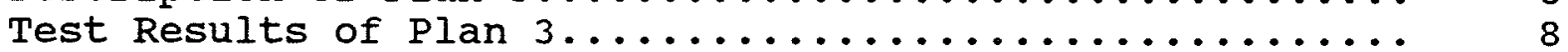

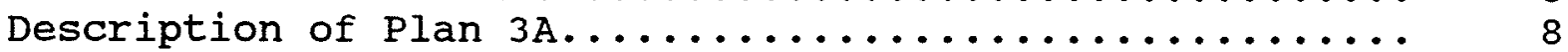

Test Results of Plan $3 A \ldots \ldots \ldots \ldots \ldots \ldots \ldots \ldots \ldots \ldots \ldots \ldots$

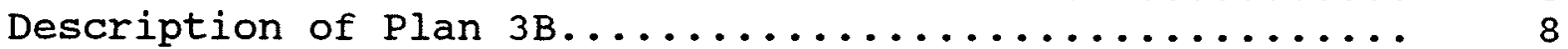

Test results of $\mathrm{Plan} 3 \mathrm{~B} \ldots \ldots \ldots \ldots \ldots \ldots \ldots \ldots \ldots \ldots \ldots \ldots \ldots$

Discussion of Plans $3,3 A$, and $3 B$ Test Results......... 9

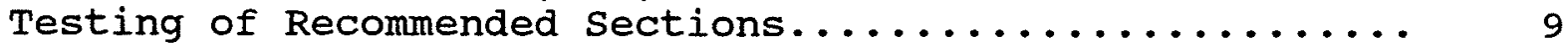

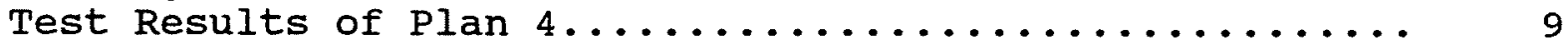

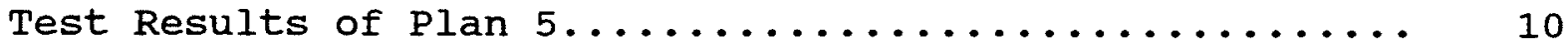

$4-$ Conclusions............................... 12

$5-$ Recommendations........................... 13

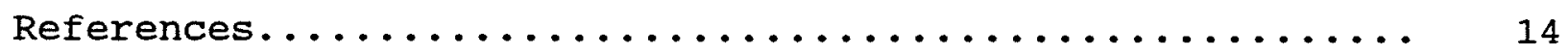

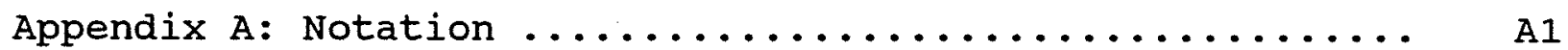

Figures $1-5$

Photos 1-96 
Preface

The model investigation described herein was requested by Consultoria Yanez-Taylor, S. A. de C. V. for Preinversion and Desarrollo, and PEMEX Refinación y Producción, and was authorized by a Technical Assistance Agreement between the Department of the Army, acting by and through the U.S. Army Engineer District, Mobile, and Taylor Engineering, Inc. Consultoria Yanez-Taylor acted as overall project manager/designer for PEMEX and as such was responsible for helping to determine test conditions, selecting breakwater sections for testing, and monitoring the direction of model tests.

The study was conducted by personnel of the coastal and Hydraulics Laboratory (CHL), U.S. Army Engineer Waterways Experiment Station (WES), under general direction of Dr. James R. Houston, Director, CHL, and Mr. Charles C. Calhoun, Jr. (retired), Assistant Director, CHL. WES is a complex of five laboratories of the Engineer Research and Development Center (ERDC). Direct guidance was provided by Messrs C. Eugene Chatham, Chief, Navigation Division (ND), CHL, and D. Donald Davidson (retired), Chief, Coastal Structures Branch, ND. Tests were conducted by Messrs. Raymond Reed and Johnny Heggins under the direction of Mr. Robert D. Carver, Principal Investigator, all of CHL. This report was prepared by Mr. Carver.

At the time this study was conducted, Director of WES was Dr. Robert $W$. Whalin. At the time of publication of this report, Commander of ERDC was COL Robin R. Cababa, EN. This report was prepared and published at the WES complex of ERDC. 
Conversion Factors, SI

To Non-SI Units of Measurement

SI units of measurement used in this report can be converted to Non-SI (English) units as follows:

Multiply

cubic metres

degrees (angle)

metres

kilograms

kilograms per

cubic metre

square metres
By

0.02831685

0.01745329

0.3048

0.4535924

0.062428

0.09290304
To obtain

cubic feet radians

feet

pounds (mass) pounds (mass) per cubic foot square feet 



\section{Introduction}

The Prototype

The Port of Dos Bocas is located on the Gulf coast of Mexico within the state of Tabasco, several miles west of the Yucatan Peninsula (Figure 1). This site has been selected for development of an oil, industrial, and commercial port to be developed through the Mexican Oil Company (PEMEX). The port will handle most of the overseas oil exports in order to improve shipping operations.

The Dos Bocas Port Development was initially planned in the late 1970's and begun in 1980. The breakwaters which protect the harbor were only partially completed when falling oil prices required that construction stop. No exportation berths were completed; however, a small terminal to send materials to offshore facilities was completed. Meanwhile, PEMEX has managed its exportation needs through two offshore buoys.

During the past three years, PEMEX has performed several marketing and economic studies which indicate the exportation of oil can no longer be managed through the existing facilities. PEMEX is now interested in completing the breakwaters. The completion includes a reevaluation of the original design.

Purpose of Model Investigation

The initial purposes of the investigation were to determine, by two-dimensional (2-D) flume tests, the stability response of three alternate armorings for the proposed breakwater and to evaluate overall performance relative to wave overtopping. Finally, based on results of the initial tests and economic considerations, the best armoring alternative would be selected and a final recommended section would be developed and tested. 


\section{The Model}

Model-Prototype Scale Relationships

Tests were conducted at geometrically undistorted scales of 1:38 and 1:40, model to prototype. Scale selection was based on the sizes of model armor available compared with the estimated size of prototype armor required for stability, elimination of wave transmission scale effects, preclusion of stability scale effects (Hudson 1975), and capabilities of the available wave tank. Based on Froude's model law (Stevens 1942) and the linear scales of $1: 38$ and 1:40, the following model-prototype relations were derived. Dimensions are in terms of length (L) and time (T) .

Model-Prototype Relation

Characteristic Dimension 1:38 Scale $\quad 1: 40$ Scale

$\begin{array}{llll}\text { Length } & \mathrm{L} & \mathrm{L}_{\mathrm{r}}=1: 38 & \mathrm{~L}_{\mathrm{r}}=1: 40 \\ \text { Area } & \mathrm{L}^{2} & \mathrm{~A}_{\mathrm{r}}=\mathrm{L}_{\mathrm{r}}{ }^{2}=1: 1444 & \mathrm{~A}_{\mathrm{r}}=1: 1600 \\ \text { Volume } & \mathrm{L}^{3} & \mathrm{~V}_{\mathrm{r}}=\mathrm{L}_{\mathrm{r}}{ }^{3}=1: 54872 & \mathrm{~V}_{\mathrm{r}}=1: 64000 \\ \text { Time } & \mathrm{T} & \mathrm{T}_{\mathrm{r}}=\mathrm{L}_{\mathrm{r}}{ }^{1 / 2}=1: 6.16 & \mathrm{~T}_{\mathrm{r}}=1: 6.32\end{array}$

The specific weight of water used in model tests was assumed to be 62.4 pcf and that of seawater is 64.0 pcf. Also, specific weights of model breakwater construction materials were not the same as their prototype counterparts. These variables were related using the following transference equation:

$$
\frac{\left(W_{a}\right)_{m}}{\left(W_{a}\right)_{p}}=\frac{\left(\gamma_{a}\right)_{m}}{\left(V_{a}\right)_{p}}\left(\frac{L_{m}}{L_{p}}\right)^{3}\left[\frac{\left(S_{a}\right)_{p}-1}{\left(S_{a}\right)_{m}-1}\right]^{3}
$$

where

$$
\begin{aligned}
W_{a}= & \text { weight of an individual armor unit, mt } \\
m, p= & \text { model and prototype quantities, respectively } \\
\gamma_{a}= & \text { specific weight of an individual armor unit, mt } \\
& \text { per cubic meter } \\
L_{m} / L_{\mathrm{p}}= & \text { linear scale of the model } \\
S_{a}= & \text { specific gravity of an individual armor unit relative } \\
& \text { to the water in which it was placed, i.e., } S_{a}=\gamma_{a} \gamma_{w}
\end{aligned}
$$


In a hydraulic model investigation of this type, gravitational forces predominate (Froudian model law), except when energy transmission through the breakwater is considered (Keulegan 1973). If the core material was geometrically scaled according to Froudian model relationships, internal Reynolds numbers would be too low, and too much energy would be dissipated. Therefore, for all plans tested, the core stone was geometrically oversized according to Keulegan (1973) to aid in reproducing wave energy transmission.

Test Equipment and Facilities

All stability tests were conducted in a $0.9-\mathrm{m}-$ wide segment of a concrete wave flume $3.4 \mathrm{~m}$ wide and $75 \mathrm{~m}$ long (Figure 2). Irregular waves were generated by a hydraulically actuated piston-type wave machine.

Wave data were collected with electrical capacitance wave gages which were calibrated daily with a computer-controlled procedure incorporating a least square fit of measurements at 11 steps. This averaging technique, using 21 voltage samples per gage, minimizes the effects of slack in the gear drives and hysteresis in the sensors. Typical calibration errors are less than 1 percent of full scale for the capacitance wave gages. Wave signal generation and data acquisition were controlled using a DEC Microvax I computer. Wave data analyses were accomplished using a DEC VAX 3600 . 
Method of Constructing Test Sections

All experimental breakwater sections were constructed to reproduce as closely as possible results of the usual methods of constructing full-scale breakwaters. The core material was dampened as it was dumped by bucket or shovel into the flume and was compacted with hand trowels to simulate natural consolidation resulting from wave action during construction of the prototype structure. Once the core material was in place, it was sprayed with a low-velocity water hose to ensure adequate compaction of the material. The underlayer stone was then added by shovel and smoothed to grade by hand or with trowels. Armor units used in the cover layer were placed in a random manner; $i . e .$, they were individually placed but were laid down without special

orientation or fitting. After each test, the armor units were removed from the breakwater, all of the underlayer stones were replaced to the grade of the original test section, and the armor was replaced.

Description of Plan 1

Plan 1 (Figure 3 and Photos 1-3) was armored with 21.6 and $12.4 \mathrm{mt}$ Acropods on the sea-side and harbor-side, respectively. Sea-side armor was buttressed against a vertical wall which had a bottom elevation of $+2.1 \mathrm{~m}$ (top of core) and a top elevation of $+8.7 \mathrm{~m}$. Armor slopes of $1 \mathrm{~V}$ on $1.5 \mathrm{H}$ were used both sea-side and harbor-side. Toe protection was provided by $3.6 \mathrm{mt}$ stone which also served as first-underlayer material.

Selection of Test Conditions

Based on siting of the breakwater, tests were conducted with a JONSWAP spectrum using a peak enhancement factor of 3.3 . A peak wave period of 12 sec was selected. A wave hindcast study (Lin, in preparation) was in progress at the time stability tests were initiated; however, it was not complete enough to provide the design wave height. Based on experience at similar sites, a proposed design wave height of $6 \mathrm{~m}$ was selected. A storm surge of $+1.135 \mathrm{~m}$, corresponding to $\mathrm{mhhw}$, was selected. The stability response of the first test section was investigated for several wave heights via the following storm hydrograph (Hydrograph 1):

$\begin{array}{ccrcr}\text { Step } & \text { SWL, m nbm } & T_{p}, \text { sec } & H_{s}, m & \text { Duration, } h r \\ 1 & +1.135 & 12.0 & 3.0 & 3.0 \\ 2 & +1.135 & 12.0 & 4.0 & 3.0 \\ 3 & +1.135 & 12.0 & 5.0 & 6.0 \\ 4 & +1.135 & 12.0 & 6.0 & 12.0\end{array}$


Test Results of Plan 1

Plan 1 exhibited an excellent stability response. As shown in Photos 4-6, no damage was evident at the conclusion of Hydrograph 1. Initialiy, it was planned to test only 3 to $6 \mathrm{~m}$ waves; however, the stability response of Plan 1 was so favorable that it was decided to extend Hydrograph 1 to include 12 hrs of 7-m waves. Again, a couple of seaward armor units were observed to rock in place; however, no displaced damage was observed either seaward or leeward.

Rationale and Description of Plan $1 \mathrm{~A}$

Based on the excellent stability response of Plan 1, it was decided to investigate alternative schemes that might improve stability or reduce the structure's cost without significantly affecting its functional performance. 'Some of the factors that govern material volumes and costs are elevation and width of the crown, type and weight of armor, and slope on which the armor is placed. It was decided that in this particular study the greatest cost savings with the least probable impact on functionality could probably be achieved by reducing the weight of both the sea-side and harbor-side armor. Appropriate model Acropods were not immediately available; however, 9- and 13-mt Core-Locs were. Therefore, Plan 1A (Figure 3) was constructed identical to Plan 1 except the 21.6- and 12.4-mt Acropods were replaced with 13- and 9-mt Core-Loc armor.

Test Results of Plan 1A

Plan IA exhibited an excellent stability response for Hydrograph 1. As with Plan 1, a couple of armor units were observed to rock in place during step 4. However, as shown in Photos 7-9, no displaced damage was observed. As with Plan 1, testing was extended with $7-\mathrm{m}$ waves. Again, no displaced damage was observed.

All of the tests described thus far were conducted at a water level of $+1.135 \mathrm{~m}$, thus intensifying wave attack on the upslope armor. For structures of this type that use armor stone as toe protection, lower water levels may leave the toe stone more vulnerable and may prove critical in determine its stability. Thus Hydrograph 2 was devised similar to Hydrograph 1, except mean lower low water, $-0.393 \mathrm{~m}$, was substituted as follows:

$\begin{array}{ccrrr}\text { Step } & \text { SWL, } m \text { nbm } & \mathrm{T}_{\mathrm{p}} \text {, sec } & \mathrm{H}_{s}, \mathrm{~m} & \text { Duration, } \mathrm{hr} \\ 1 & -0.393 & 12.0 & 3.0 & 3.0 \\ 2 & -0.393 & 12.0 & 4.0 & 3.0 \\ 3 & -0.393 & 12.0 & 5.0 & 6.0 \\ 4 & -0.393 & 12.0 & 6.0 & 12.0\end{array}$


Without rebuilding, Plan $1 \mathrm{~A}$ was subjected to Hydrograph 2 . No damage was observed during steps 1 and 2 . Step 3 produced some in-place movement of the $3.6 \mathrm{mt}$ toe stone. Toe-stone movement increased during step 4 , with about 3 percent of the material being displaced seaward. No core-Loc movement was observed for any of the test conditions. Photos 10-12 show the structure at the conclusion of testing.

Rationale and Description of Plan $1 \mathrm{~B}$

Based on the excellent stability response of $\mathrm{Plan} 1 \mathrm{~A}$, an additional improvement was investigated. This improvement consisted of reducing the leeward Core-Loc armor weight to 5.5mt. The new structure, Plan 1B, was tested with Hydrograph 1. Also, prior to testing, all spectral signals were rephased.

Test Results of Plan 1B

Consistent with previously described structures, Plan 1B exhibited an excellent stability response. No movement was observed during steps 1 and 2 . Step $3,5 \mathrm{~m}$ waves, produced rocking of two seaward armor units in the vicinity of the swl. Downslope displacement of one armor unit was observed during attack of the 6-m waves. Photos 13-15 show the structure at the conclusion of Hydrograph 1. Again, tests were extended with 7-m waves and one additional seaward armor unit was displaced. As shown in Photos 16-18, the final condition of the structure was excellent with the two displaced armor units representing less than 1 percent of the seaward armor units. No damage was observed on the leeward side of the structure.

Rationale and Description of Plan 1C

In order to identify as many stable options for the prototype breakwater as possible, a final Acropod section was tested. Plan 1C (Photos 19-21) was created by armoring the seaward slope with the 12.4-mt Acropods which were previously used on the harborside of Plan 1. Due to the unavailability of smaller Acropods, the 5.5-mt Core-Loc armor was retained on the leeward slope.

Test Results of Plan 1C

As with previous structures, Plan 1C was initially tested with Hydrograph 1 . No armor movement was detected during steps 1-3. Attack of $6-\mathrm{m}$ waves, step 4 , initiated rocking of two seaward armor units in the vicinity of the swl; however, no displacement was observed. Testing with 7-m waves produced downslope displacement of one seaward armor unit. As shown in Photos 22-24, the structure was still in excellent condition at the conclusion of testing. 
Discussion of Plan 1, 1A, $1 B$ and 1C Test Results

In summary, Plans $1,1 \mathrm{~A}, 1 \mathrm{~B}$, and $1 \mathrm{C}$ are all stable alternatives for the proposed breakwater. The 21.6- and 12.4-mt Acropods used on Plan 1 are conservatively stable. The 13-mt Core-Locs used on the seaward face of Plan 1A also proved stable and the 9-mt core-Locs used on the leeward face were again conservative. Plans $1 \mathrm{~B}$ and $1 \mathrm{C}$ showed that the leeward armor can be further reduced to $5.5 \mathrm{mt}$ and $13-\mathrm{mt}$ Acropods or Core-Locs should prove stable on the exposed face.

Description of Plan 2

Plan 2 (Figure 3 and Photos 25-27) was protected by two layers of Tetrapod armor. Armor weights of 16- and 3-mt were used sea-side and harbor-side, respectively.

Test Results of Plan 2

Plan 2 was tested with Hydrograph 1 . No damage was observed during steps 1 and 2 . Step 3,5 m waves, produced in-place rocking of about 2 percent of the seaward Tetrapods. Movement increased with the $6 \mathrm{~m}$ waves. During the course of step 4 , approximately 4 percent of the seaward armor was displaced downslope and onto the toe of the structure. Also, about 3 percent of the upper slope leeward armor was displaced downslope.

The final condition of the structure, shown in Photos 28-30, was considered unacceptable for the $6-\mathrm{m}$ waves.

Thus, the initial test of Plan 2 showed that the selected Tetrapods were stable for $5-\mathrm{m}$ waves and unacceptable for $6-\mathrm{m}$ waves. In an effort to refine the design wave height, a repeat test was conducted in which $5.5-\mathrm{m}$ waves were added to the test.

Plan 2 was rebuilt and retested. Again, no displaced damage was observed for the $3-, 4-$ and $5-\mathrm{m}$ waves. The $5.5-\mathrm{m}$ waves displaced 1.5 percent of the armor downslope; however, the condition of the structure was still considered acceptable after attack of the 5.5-m waves (Photos 31-33). Damage increased as the structure was tested with 6-m waves. As shown in photos 3436 , the final condition of the structure was not acceptable with about 5 percent of the armor units displaced downslope on both armor slopes.

Based on direct results of the repeat test and inference from the initial test, the 16-mt Tetrapods should be stable for wave heights up to $5.5 \mathrm{~m}$. As opposed to the one layer armor systems (Core-Locs and Acropods) previously reported, the Tetrapods exhibited significantly lower stability. 
Description of Plan 3

Plan 3 was armored with two layers of 10- and 5-mt Antifer Cubes on the seaside and harborside, respectively. Photos 37-39 show the test section prior to wave attack.

Test Results of Plan 3

Plan 3 exhibited an excellent stability response. No armor movement was observed during steps 1-3 of Hydrograph 1 . Step 4, 6-m waves, displaced one armor unit. As shown in Photos 40-42, the structure was still in excellent condition at the conclusion of Hydrograph 1 . Testing continued with $7-\mathrm{m}$ waves. The 7-m waves displaced two additional sea-side armor units (Photos 4345).

Description of Plan $3 A$

As shown in photos of Plan 3, the armor units were placed as close together as possible, without forming a pattern. It was felt that this close placement may have contributed to the excellent stability response. Therefore, it was decided to test another plan that would employ a more random placement of the cubes. Plan 3A, Photos 46-48, was identical to Plan 3 , except the armor was placed in a more random manner. This reduced the required number of armor units and increased the porosity of the cover layer from $25 \%$ to $42 \%$.

Test Results of Plan 3A

Despite the more random placement of the armor units, Plan $3 \mathrm{~A}$ also exhibited an excellent stability response. Photos 49-51 show there was no displaced damage at the end of Hydrograph 1. Photos 52-54 show the structure with two armor units displaced seaward and one armor unit displaced leeward at conclusion of testing with 7-m waves.

Description of Plan 3B

Since Plans 3 and $3 A$ produced very similar results, it was decided to try one additional plan in which the armor placement was more randomized. This was accomplished by placing about 5 armor units at a time on the end of a shovel and letting the units fall gently into place. Results of this placement technique, Photos 55-57, show that a significant increase in the randomness of the armor was achieved. As would be expected, porosity also increased from $42 \%$ to $52 \%$.

Test Results of Plan 3B

No armor movement was detected during attack of the 3- and 4-m waves. Minor in-place rocking of 2 seaward units was 
observed during 5-m wave attack. As shown in Photos 58-60, one armor unit was displaced downslope on both the seaside and harborside faces by the conclusion of Hydrograph 1. Damage became more extensive during attack of the 7-m waves. Four armor units were displaced from the seaward face and 7 armor units were displaced downslope on the back of the structure. Photos 61-63 show the structure at the conclusion of testing.

It was decided to conduct a repeat test of $\mathrm{Plan} 3 \mathrm{~B}$, in order to verify the stability response associated with the higher porosity. As shown in Photos 64-66 the structure was still in acceptable condition at the conclusion of Hydrograph 1 with two armor units displaced from the seaward face and 5 units displaced from the leeward face. A comparison of Photos 64-66 with Photos 58-60 shows similar results at this point in the test. As shown in Photos 67-69, totals of 4 and 9 armor units were displaced seaside and leeside, respectively, by the conclusion of testing. Verifying results of the first test, the structure was considered to be in acceptable condition at the end of testing.

Discussion of $\mathrm{Plan} 3,3 \mathrm{~A}$, and $3 \mathrm{~B}$ Test Results

As tests progressed from Plan 3 to $3 \mathrm{~A}$ and finally $3 \mathrm{~B}$, placement of the armor became more random, porosity increased and some increase in displaced damage was noted. However, all plans were acceptable for 7-m waves.

Testing of Recommended Sections

Based on tests and results previously described and a sponsor performed economic analysis of the various alternatives, Core-Locs were chosen as the optimum armor. Plans $3,3 \mathrm{~A}$, and $3 \mathrm{~B}$ showed that 10- and 5-mt Antifer Cubes would have been acceptable; however, the two-layer cube armor would have required significantly more concrete than the final core-Loc plans.

The final test sections, Plans 4 and 5 , consisted of testing $13 \mathrm{mt}$ Core-Locs in a water depth of $11 \mathrm{~m}$ and $15 \mathrm{mt}$ Core-Locs in a water depth of $15 \mathrm{~m}$. As with previous plans, the $1.5-\mathrm{m}$ toe trenching was not represented, thus giving controlling depths of 11 and $15 \mathrm{~m}$ at the base of the core. Details of Plan 4 are shown in Figure 4 and Photos 70-72. The structure is very similar to Plans $1 \mathrm{~A}$ and $1 \mathrm{~B}$, except the crown wall is improved and the harbor-side armor now consists of $4.5-\mathrm{mt}$ stone.

Test Results of Plan 4

Plan 4 exhibited an excellent stability response for Hydrograph 1. As shown in Photos 73-75, no damage was evident at the conclusion of Hydrograph 1. Testing was extended with 7-m waves with no displaced damage being observed. Photos 76-78 show the structure after testing with the $7-m$ waves. 
As discussed earlier in this report, for structures of this type that use armor stone as toe protection, lower water levels may leave the toe stone more vulnerable and prove critical in determining its stability. Thus, in an effort to focus more wave energy on the toe, Plan 4 was also tested with Hydrograph 2. Some minor reorientation of the seaward toe stone was observed during attack of the 5 and $6 \mathrm{~m}$ waves. No Core-Loc movement was observed for any of the test conditions. Photos 79-81 show Plan 4 to be in excellent condition after testing both hydrographs.

Plan 4 was rebuilt and a repeat test was conducted with Hydrograph 1 plus the 7-m waves. Again, some minor in-place armor reorientation was observed. However, no displaced damage was noted. Photos 82-84 show the structure at the conclusion of testing.

Test Results of Plan 5

Plan 5 represented a section of the breakwater that will be near the head; whereas, all previously discussed plans were assumed to be in a more intermediate water depth. Plan 5 (Figure 5 and Photos 85-87) was similar to Plan 4 except the water depth was increased to $15 \mathrm{~m}$ and the primary armor weight was increased to $15 \mathrm{mt}$. In order to properly simulate the $15 \mathrm{mt}$ Core-Locs, the model scale was reduced from 1:38 to $1: 40$ and the same model armor from Plan 4 was used.

A major objective in testing Plan 5 was to determine if the deeper water would allow more extreme waves to reach the structure, for a constant significant wave height, and thus increase wave overtopping and this is what did occur. The structure was tested with Hydrograph 1 , with only minor reorientation of a few armor units occurring. However, attack of the $7-\mathrm{m}$ waves produced minor overtopping of the seawall. As shown in Photos 88-90, this overtopping displaced a few of the $4.5 \mathrm{mt}$ lee-ward armor stones at the top of the slope. The number displaced was less than 2 percent of the total and no core-Loc displacement was observed.

Plan 5 was rebuilt and again exposed to Hydrograph 1 plus the $7-\mathrm{m}$ waves with basically the same results as the initial test; $i$. e., less than 2 percent of $4.5 \mathrm{mt}$ lee-ward armor was displaced and no core-Loc displacement was observed. Photos 9193 show the structure after attack of the $7-\mathrm{m}$ waves. It is felt that Plan 5 is adequate for up to $7-\mathrm{m}$ waves at this depth; however, the top elevation of the seawall is only minimally acceptable as opposed to being completely acceptable in a depth of $11 \mathrm{~m}$ or less. 
Even though Plan 5 showed excellent performance for waves in excess of the proposed design height of $6.5 \mathrm{~m}$, experience has shown that breakwater damage can initiate and progress quite rapidly with only a small increase in wave height. Therefore, it was decided to extend the repeat test of Plan 5 with $8-m$ waves, in an effort to estimate the structures reserve stability.

Photos 94-96 show that the Core-Loc armor was still in excellent condition at the conclusion of testing with 8-m waves; however, the 4.5-mt, lee-ward armor experienced about 15 percent displaced damage. Damage on the lee-ward side was a direct result of significant wave overtopping, confirming the above mentioned judgement that the top elevation of the seawall would need to be increased for protection from waves in excess of $7-\mathrm{m}$. 


\section{Conclusions}

that:

Based on tests and results reported herein, it is concluded

a. The 21.6- and 12.4-mt Acropods used on Plan 1 proved to be conservatively stable.

b. The 13-mt core-Locs used on the seaward face of Plan 1A proved to be stable and the 9-mt Core-Locs used on the leeward face were conservatively stable.

c. Plans $1 \mathrm{~B}$ and $1 \mathrm{C}$ showed that the leeward Core-Loc armor can be further reduced to $5.5 \mathrm{mt}$.

d. Plan 2, armored with 16- and 3- mt Tetrapods, experienced instability for wave heights above $5.5 \mathrm{~m}$. Tetrapod stability was significantly less than that observed for the Core-Loc and Acropod structures.

e. Plans 3, 3A, and 3B, armored with two layers of 10- and 5-mt Antifer Cubes on the seaside and harborside, respectively proved stable for 7-m waves, even though placement became more random and porosity progressively increased from Plan 3 to $3 B$.

f. Plan 4, armored with 13-mt Core-Locs on the seaside, 4.5-mt stone on the leeside and using a crownwall elevation of $+10.3 \mathrm{~m}$, proved to be stable for significant wave heights of $7 \mathrm{~m}$.

g. Plan 5, similar to Plan 4 except the water depth was increased to $15 \mathrm{~m}$ and the sea-side, Core-Loc armor weight was increased to $15 \mathrm{mt}$, also proved stable for significant wave heights of $7 \mathrm{~m}$.

h. Plan 5, when subjected to significant wave heights of 8$\mathrm{m}$, experienced damage to the lee-ward armor; however, the 15-mt Core-Locs showed acceptable stability. 
The final test sections, Plans 4 and 5 , consisting of $13 \mathrm{mt}$ Core-Locs in a water depth of $11 \mathrm{~m}$ and $15 \mathrm{mt}$ Core-Locs in a water depth of $15 \mathrm{~m}$ proved to be stable for significant wave heights up to $7 \mathrm{~m}$. These armor weights are recommended for prototype use. Also, the crownwall elevation of $+10.3 \mathrm{~m}$ should be adequate for significant wave heights up to and including $7 \mathrm{~m}$. 
Goda, Y. and Suzuki, Y., (1976). "Estimation of incident and reflected waves in random wave experiments," Proceedings, 15th International Conference on Coastal Engineering, Honolulu, Hawaii.

Hudson, R. Y. (1975). "Reliability of rubble-mound breakwater stability models," Miscellaneous Paper H-75-5, U.S. Army Engineer Waterways Experiment station, Vicksburg, MS

Keulegan, G. H. (1973). "Wave transmission through rock structures, "Research Report H-73-1, U.S. Army Engineer Waterways Experiment station, Vicksburg, MS

Lin, L. W. (In Preparation). "Evaluation of Wave Climate for Dos Bocas Oil Port," Technical Report CHL-99-, U.S. Army Engineer Waterways Experiment Station, Vicksburg, MS

Stevens, J. C. 1942. "Hydraulic Models," Manuals of Engineering Practice No. 25, American Society of Civil Engineers, New York. 
Appendix A: Notation

A Acceleration due to gravity, ft/ $\mathrm{sec}^{2}$

d Water depth, ft

d/L Relative depth, dimensionless

$\mathrm{H}_{\mathrm{mo}} \quad$ Zero-moment wave height, ft

$\mathrm{L}_{\mathrm{p}} \quad$ Airy wave length, ft

$R_{N} \quad$ Reynolds stability number

$\mathrm{T}_{\mathrm{p}} \quad$ Wave period of peak energy density of spectrum, sec

W Weight, 1b

$\alpha \quad$ Angle of breakwater slope, measured from horizontal, deg

cota Reciprocal of breakwater slope

$\gamma \quad$ specific weight, pcf

$v_{a}$ Specific weight of armor unit, pcf 


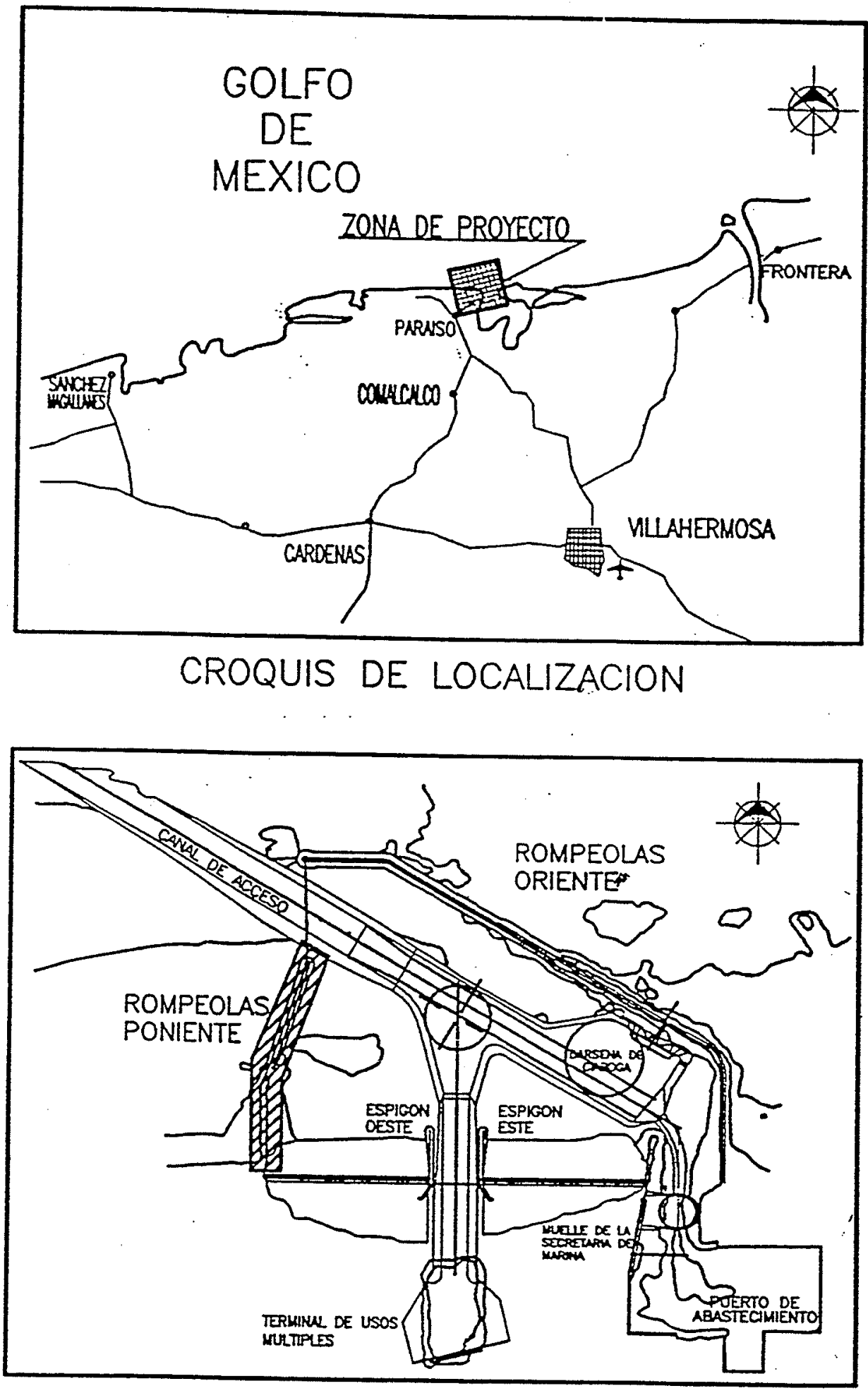

Figure 1. Location map 

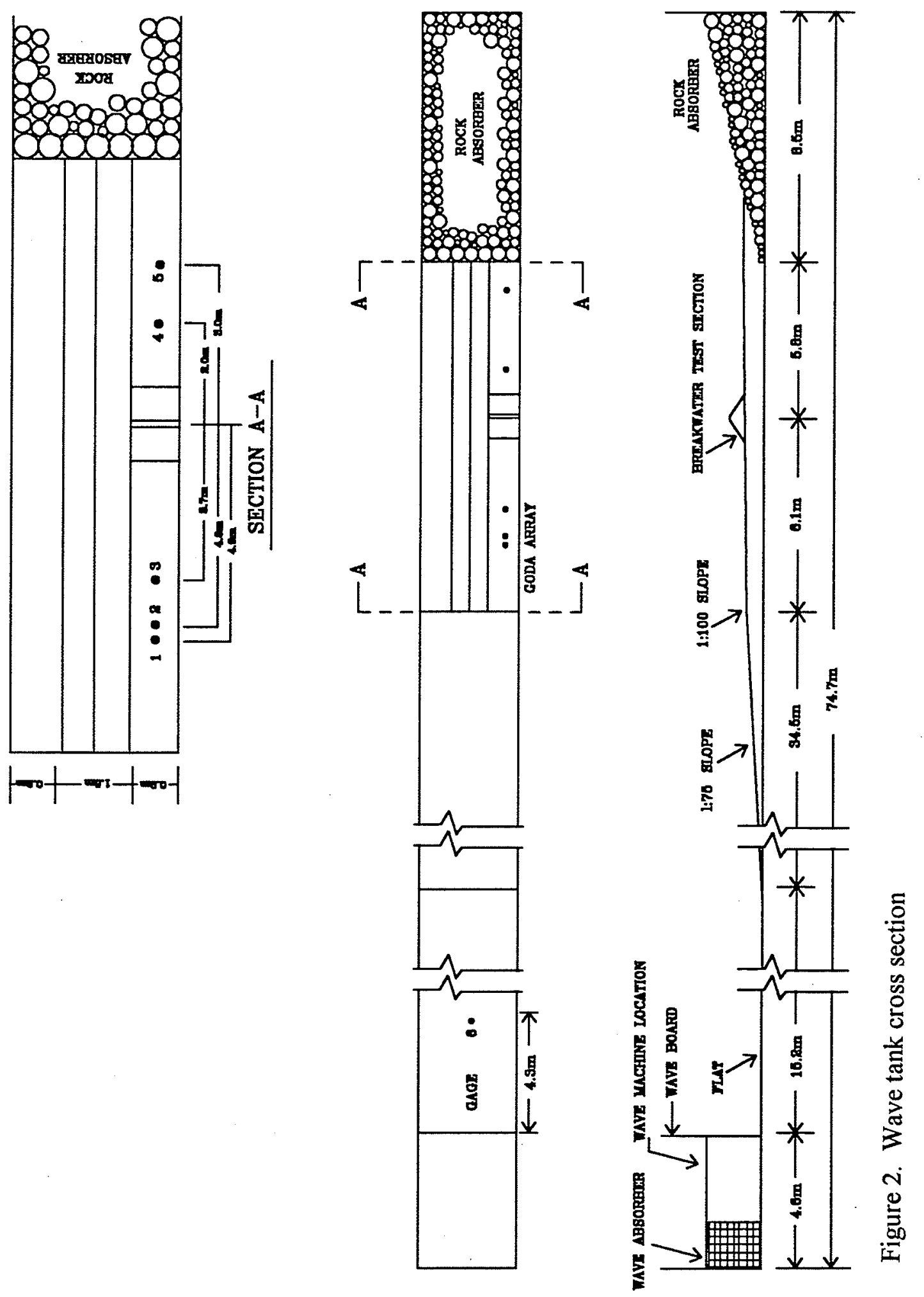


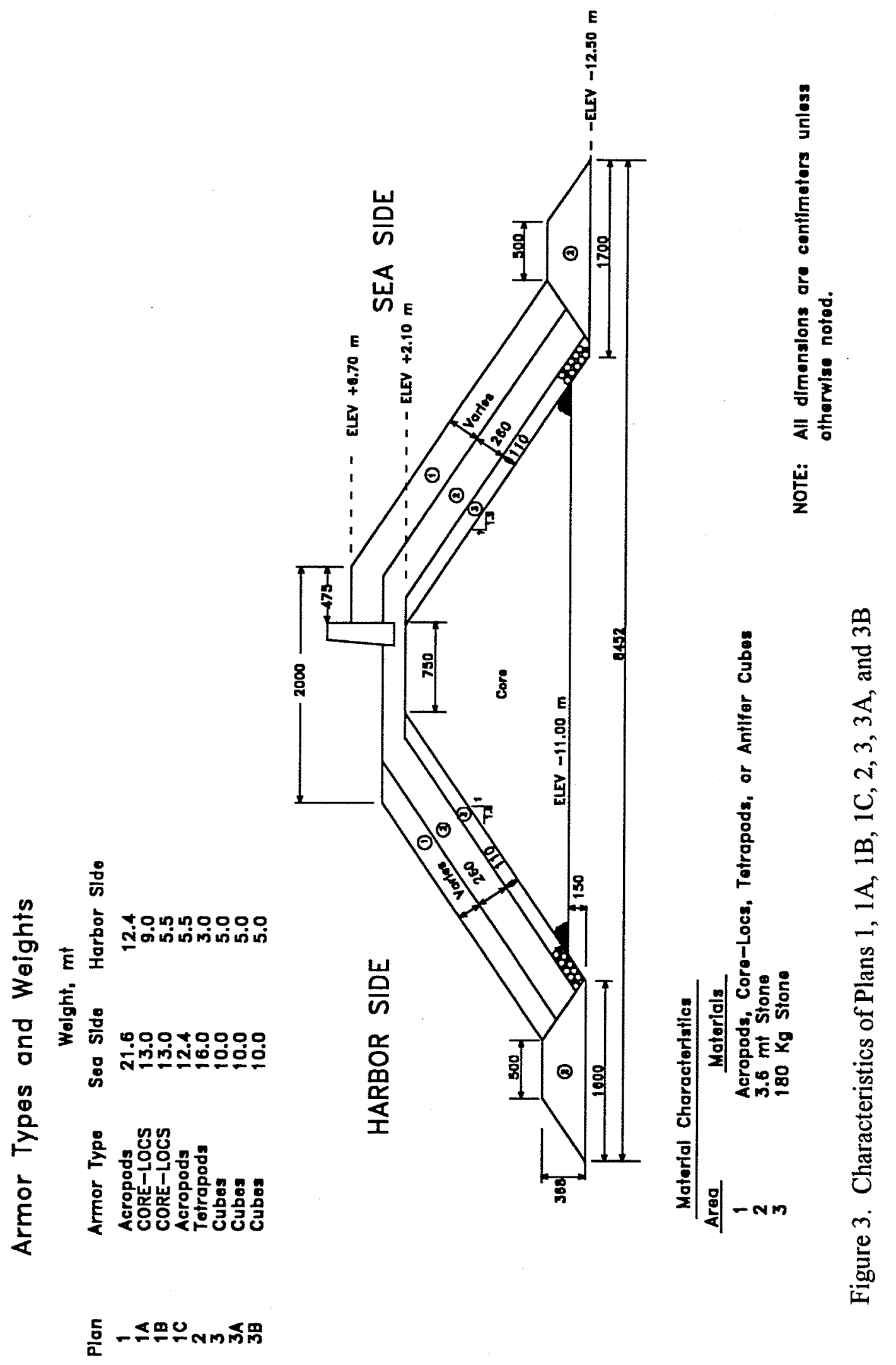




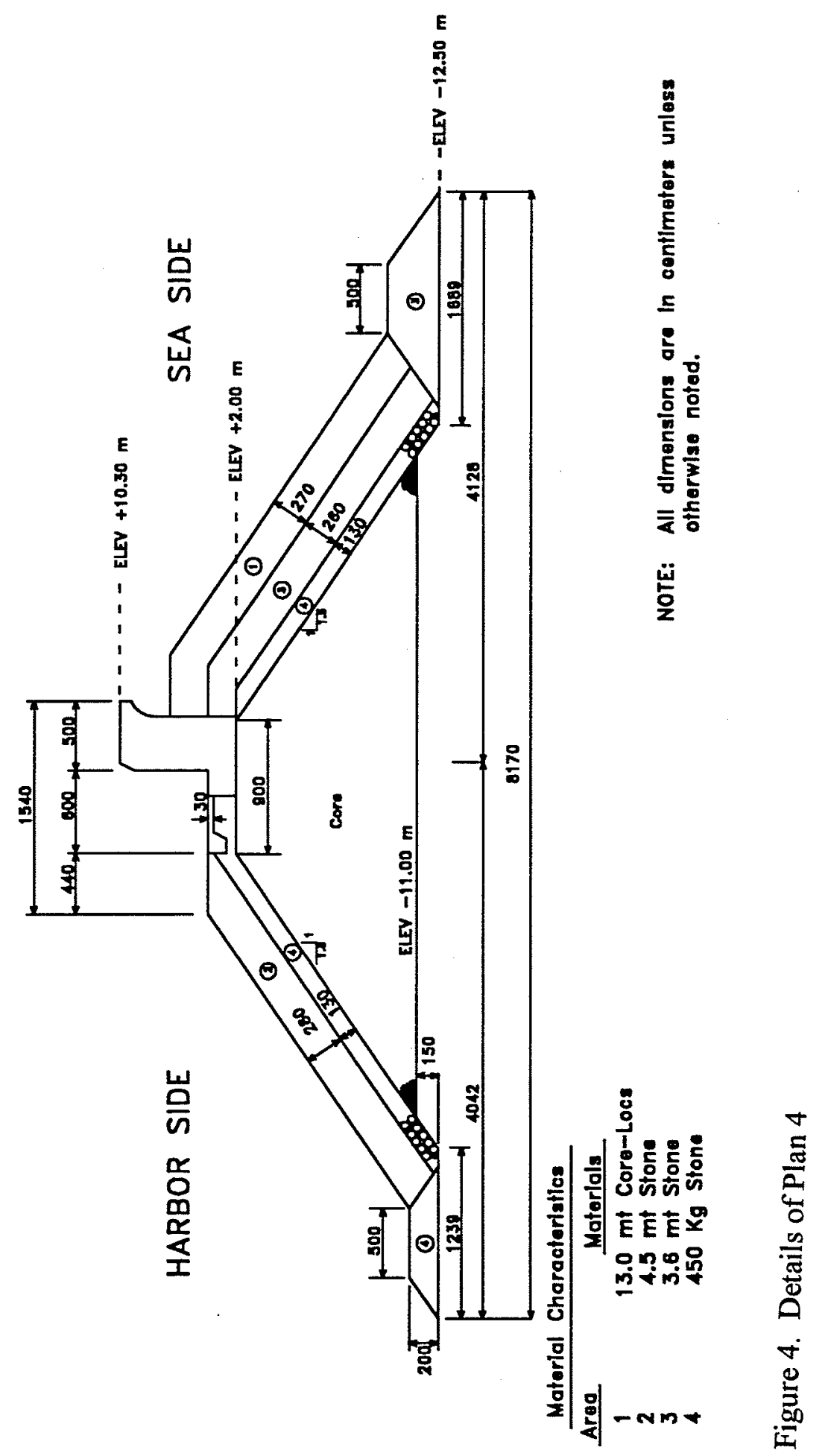




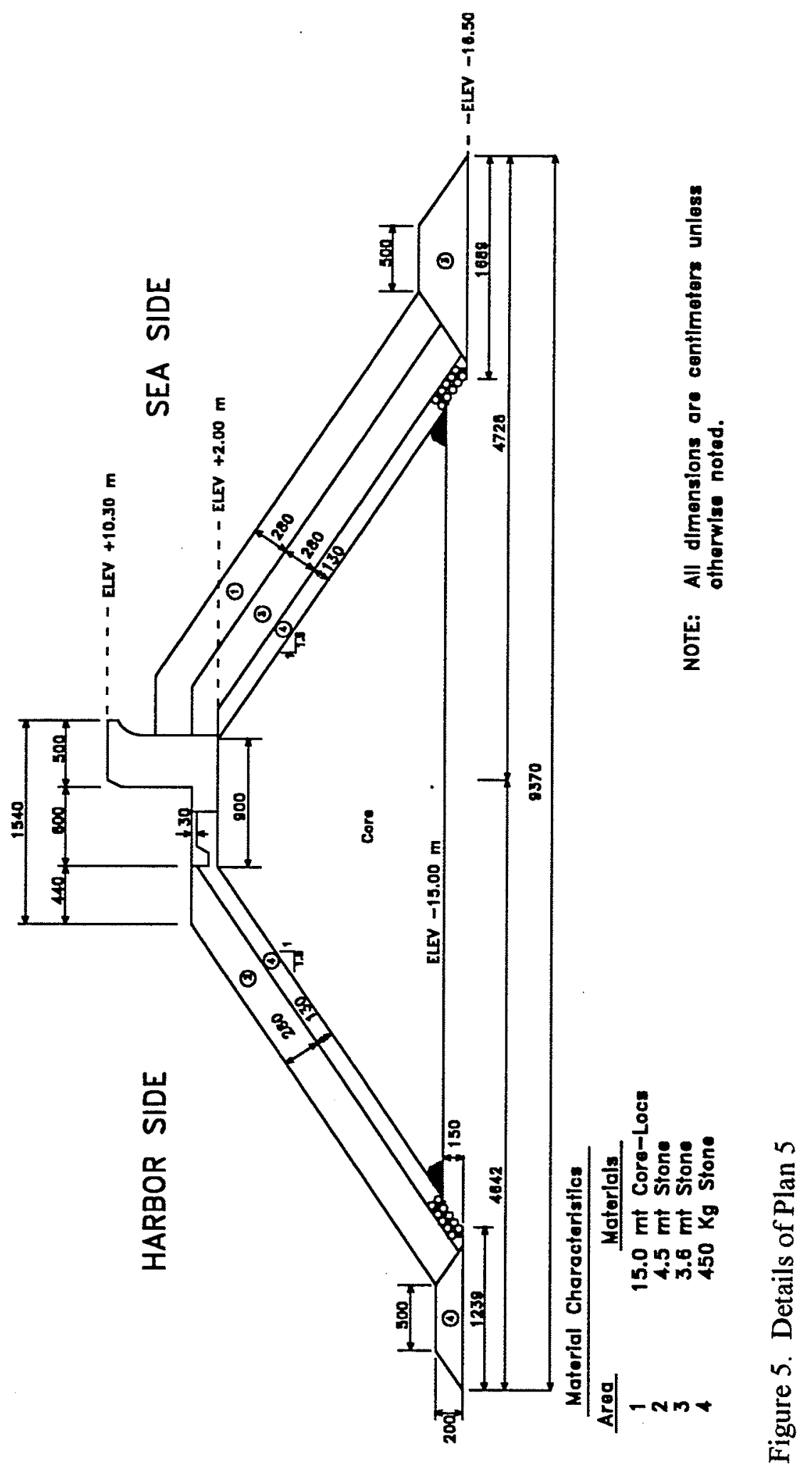




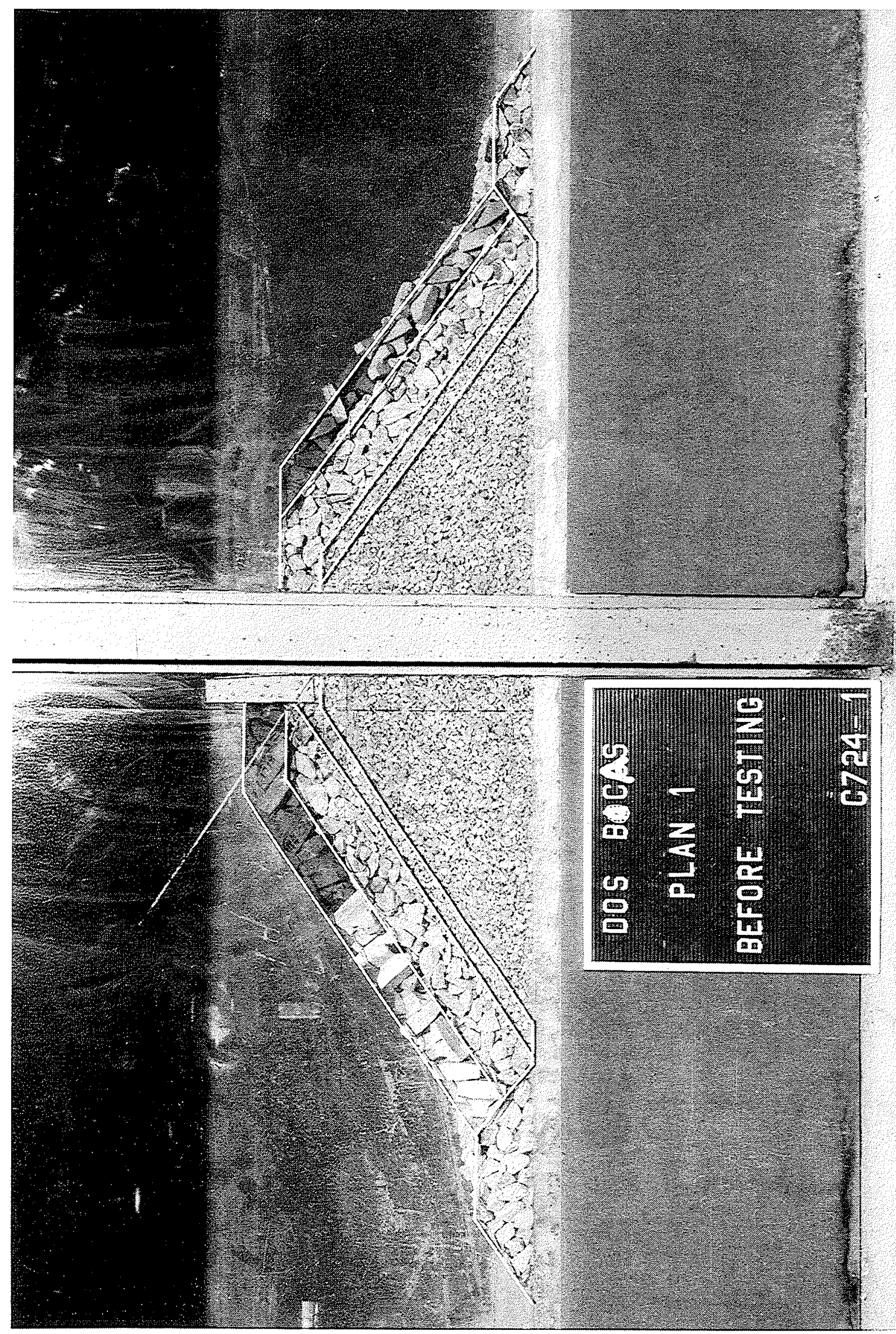

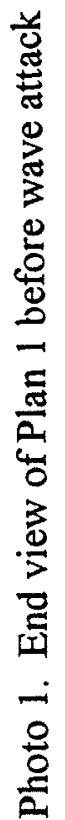




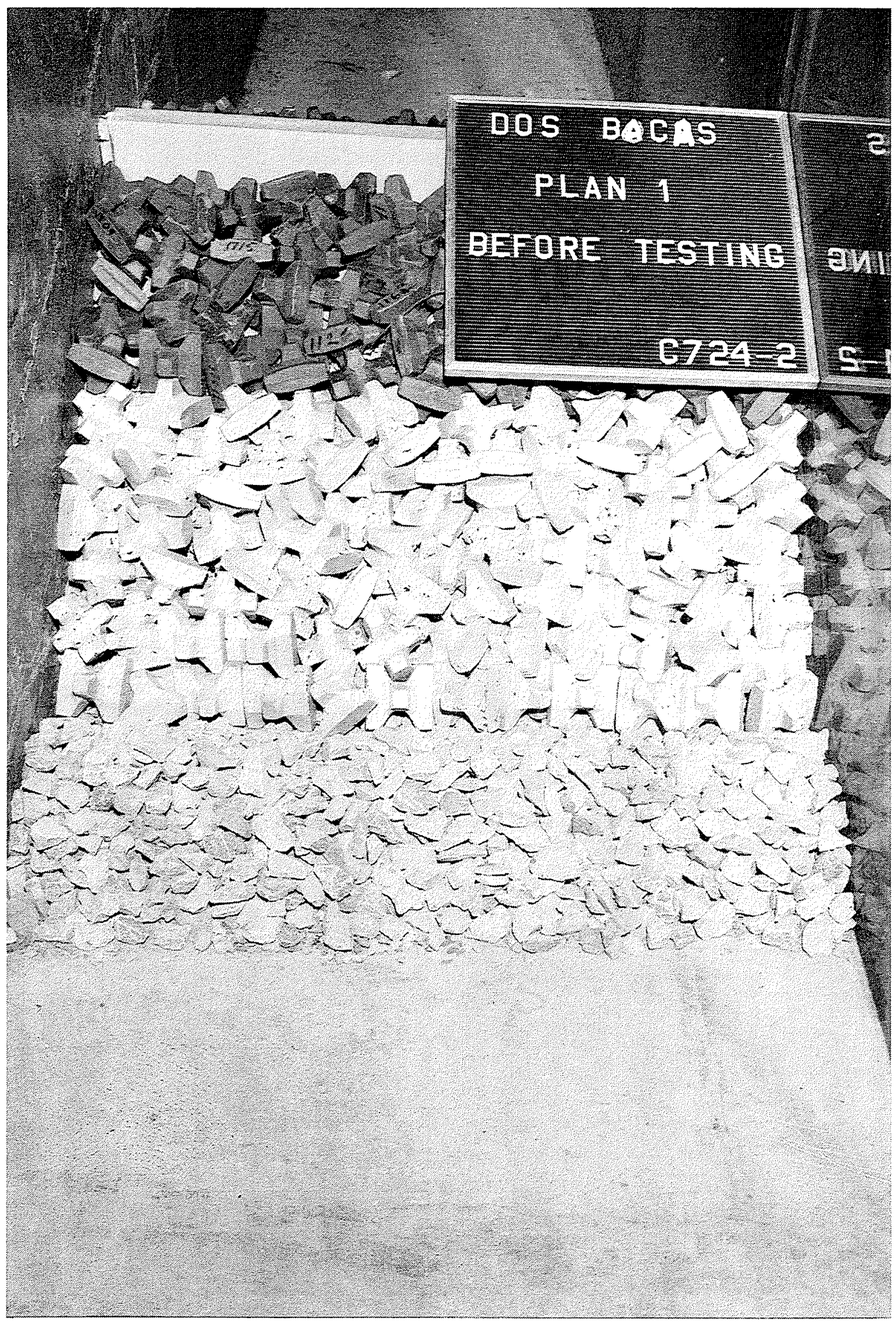

Photo 2. Sea-side view of Plan 1 before wave attack 


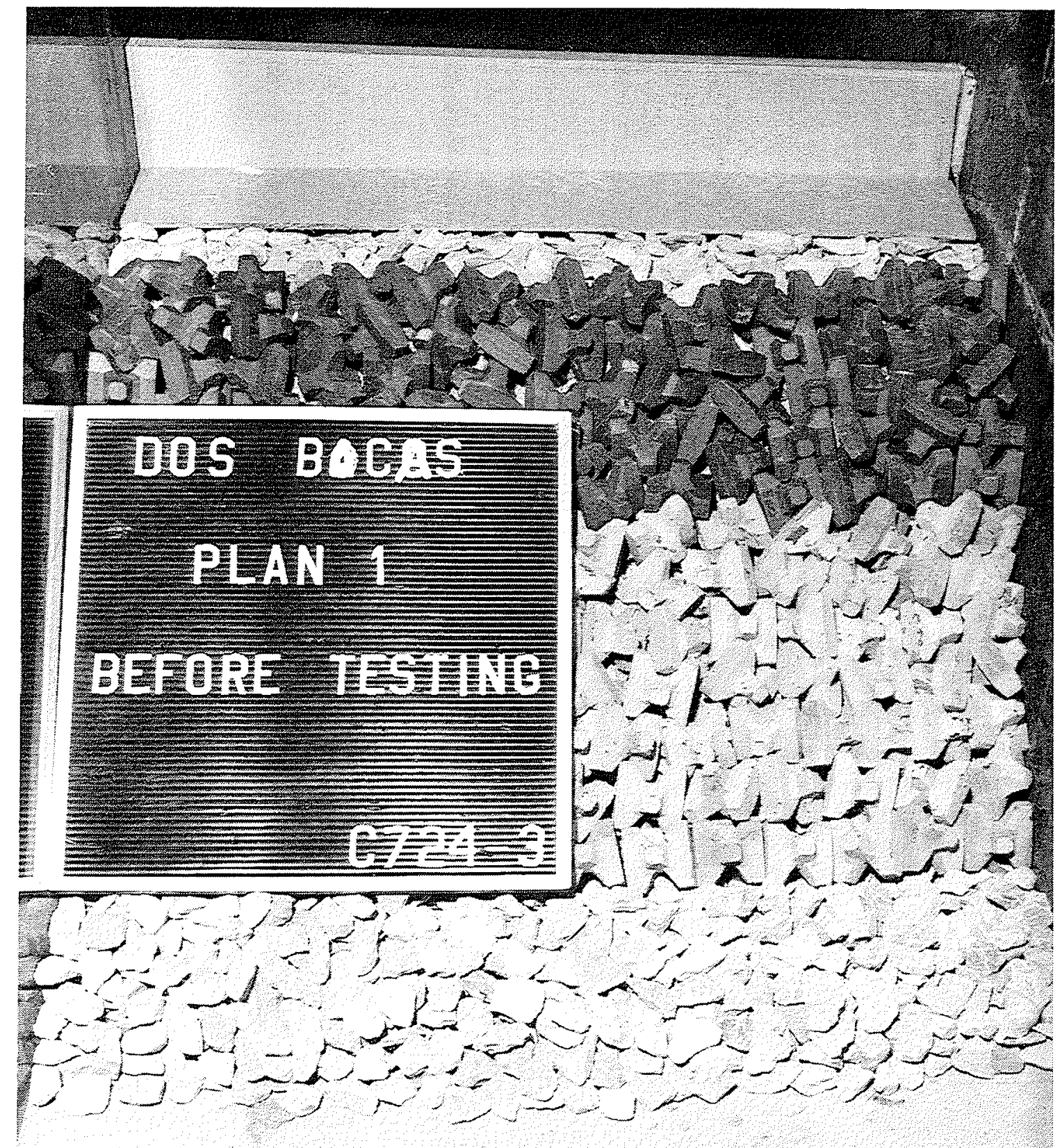

Photo 3. Harbor-side view of Plan 1 before wave attack 

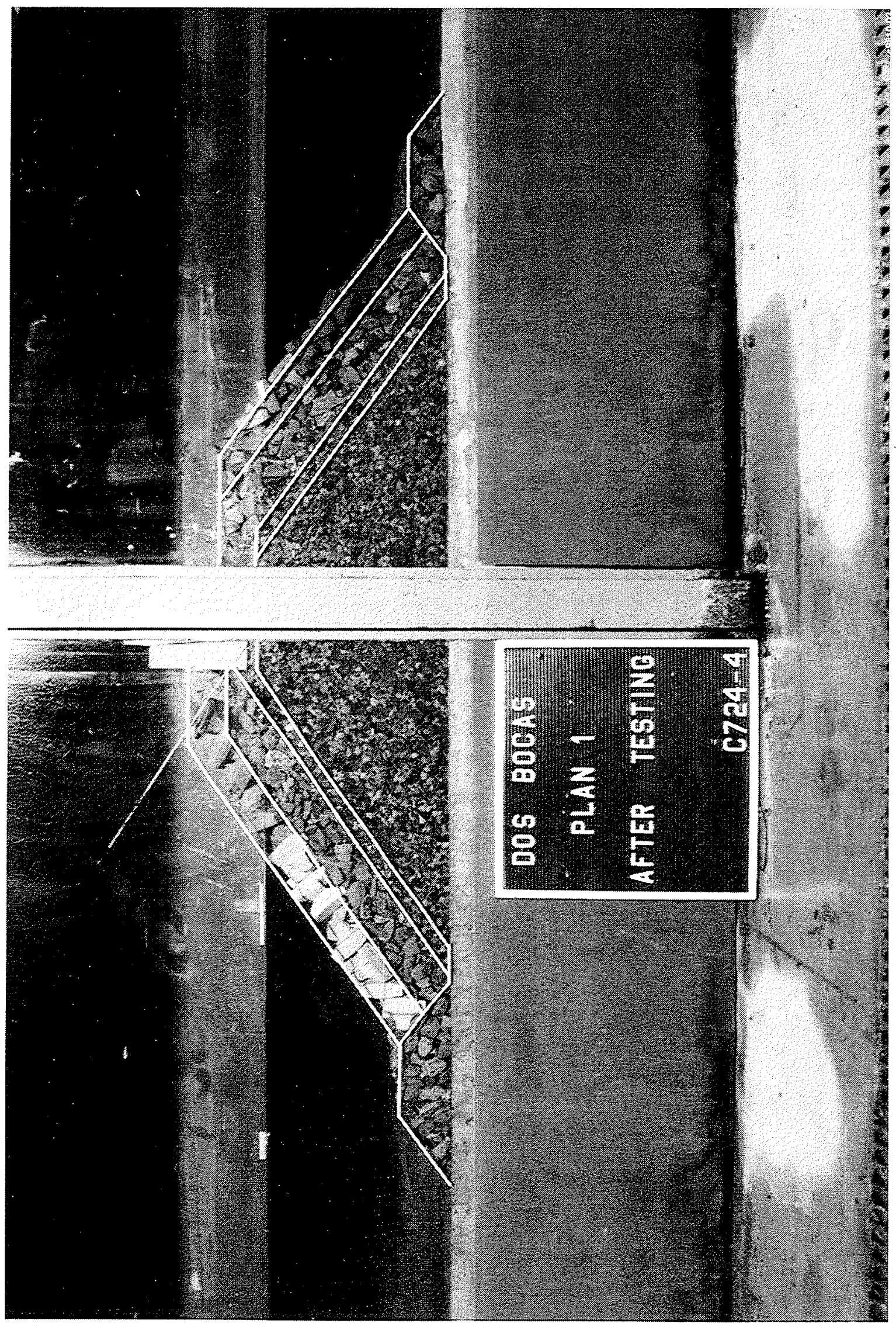

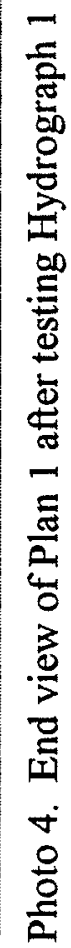




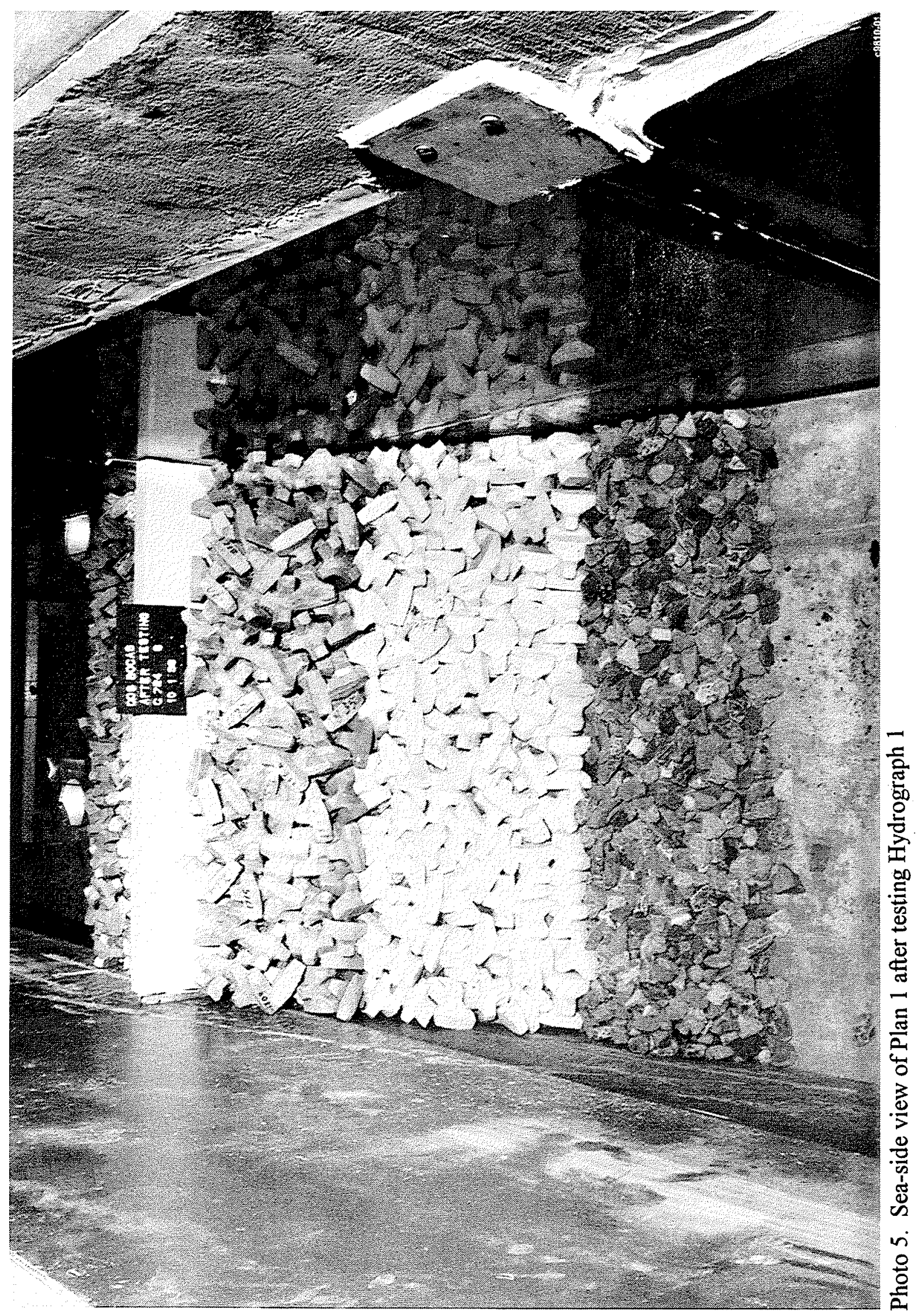




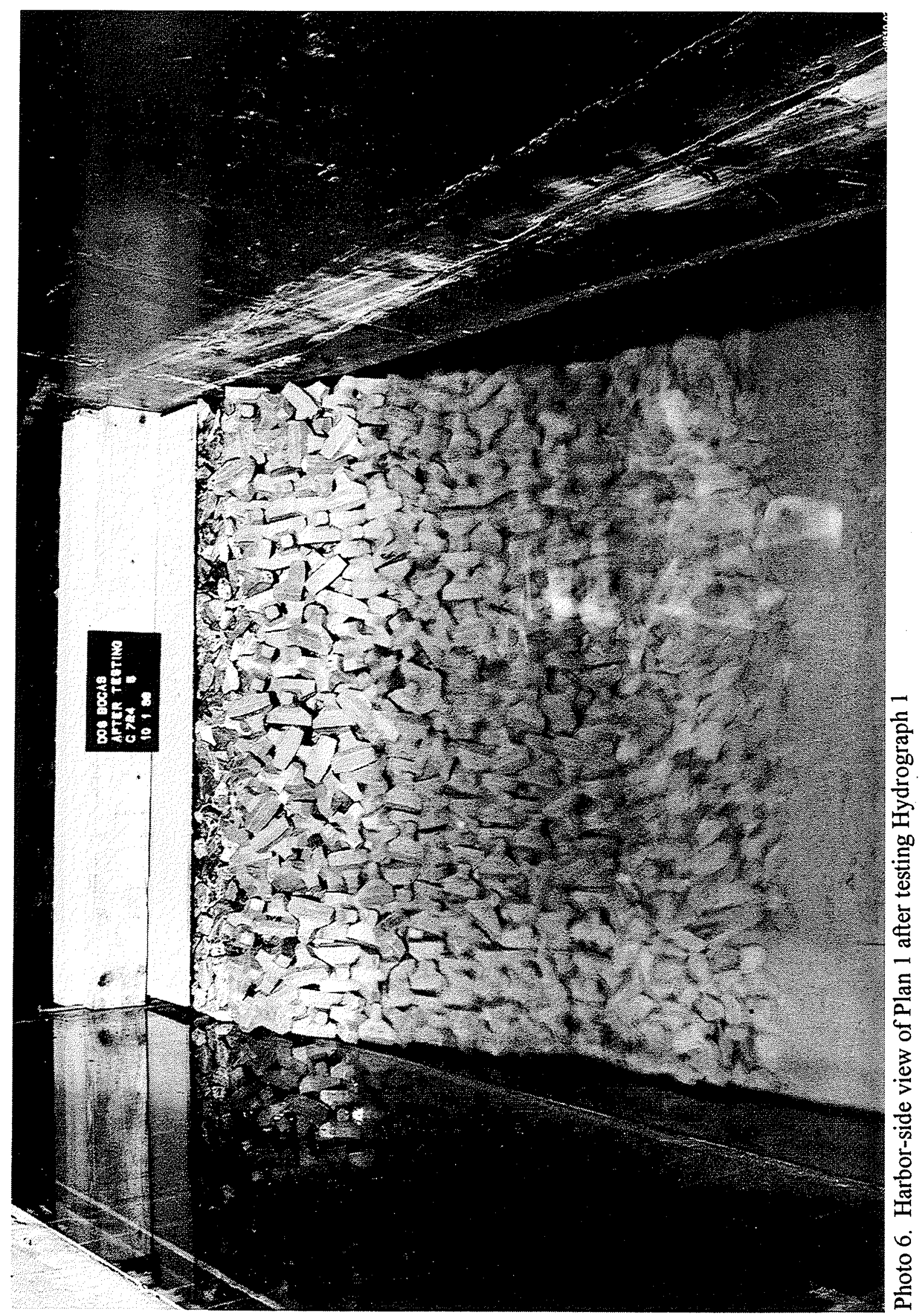




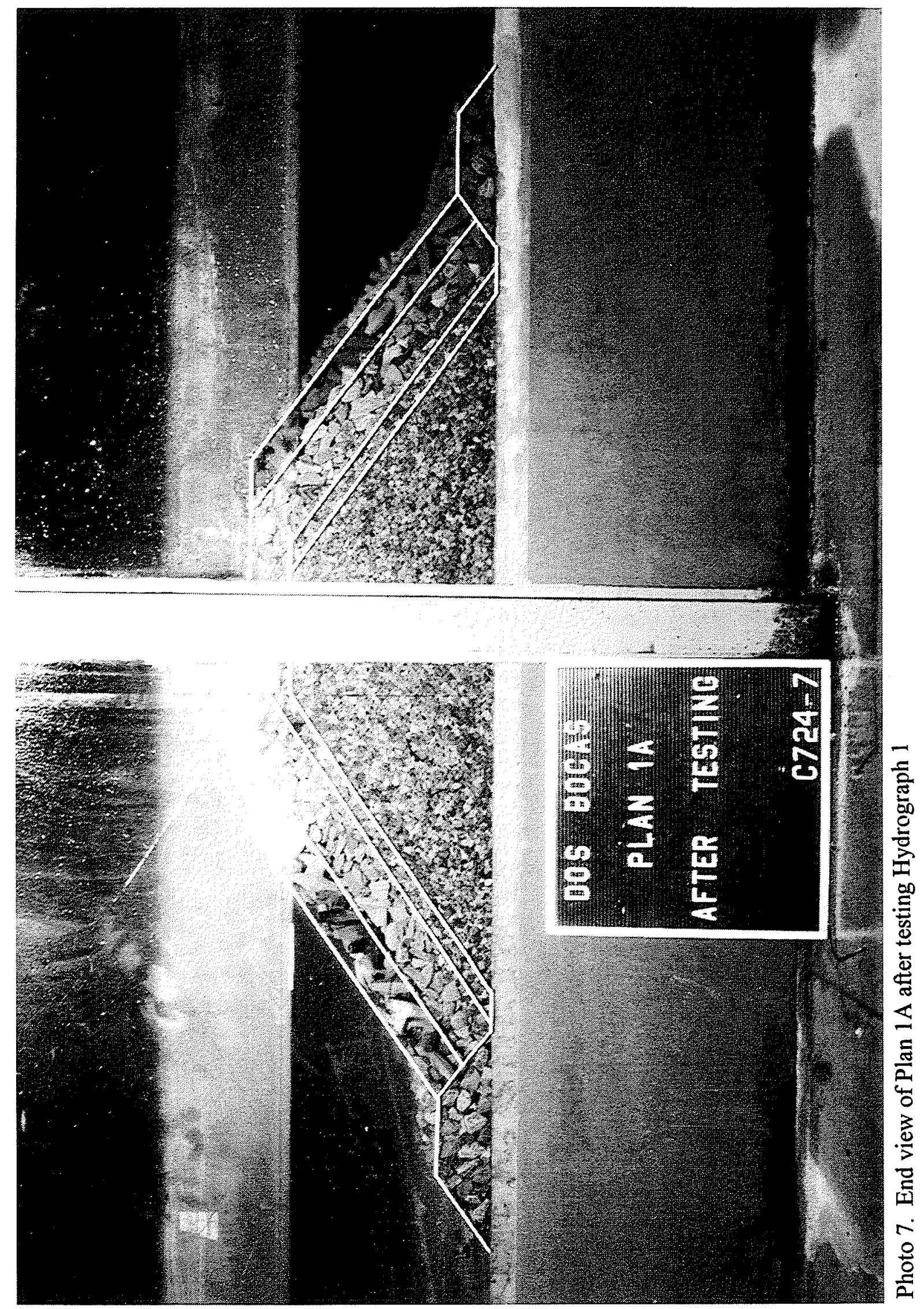




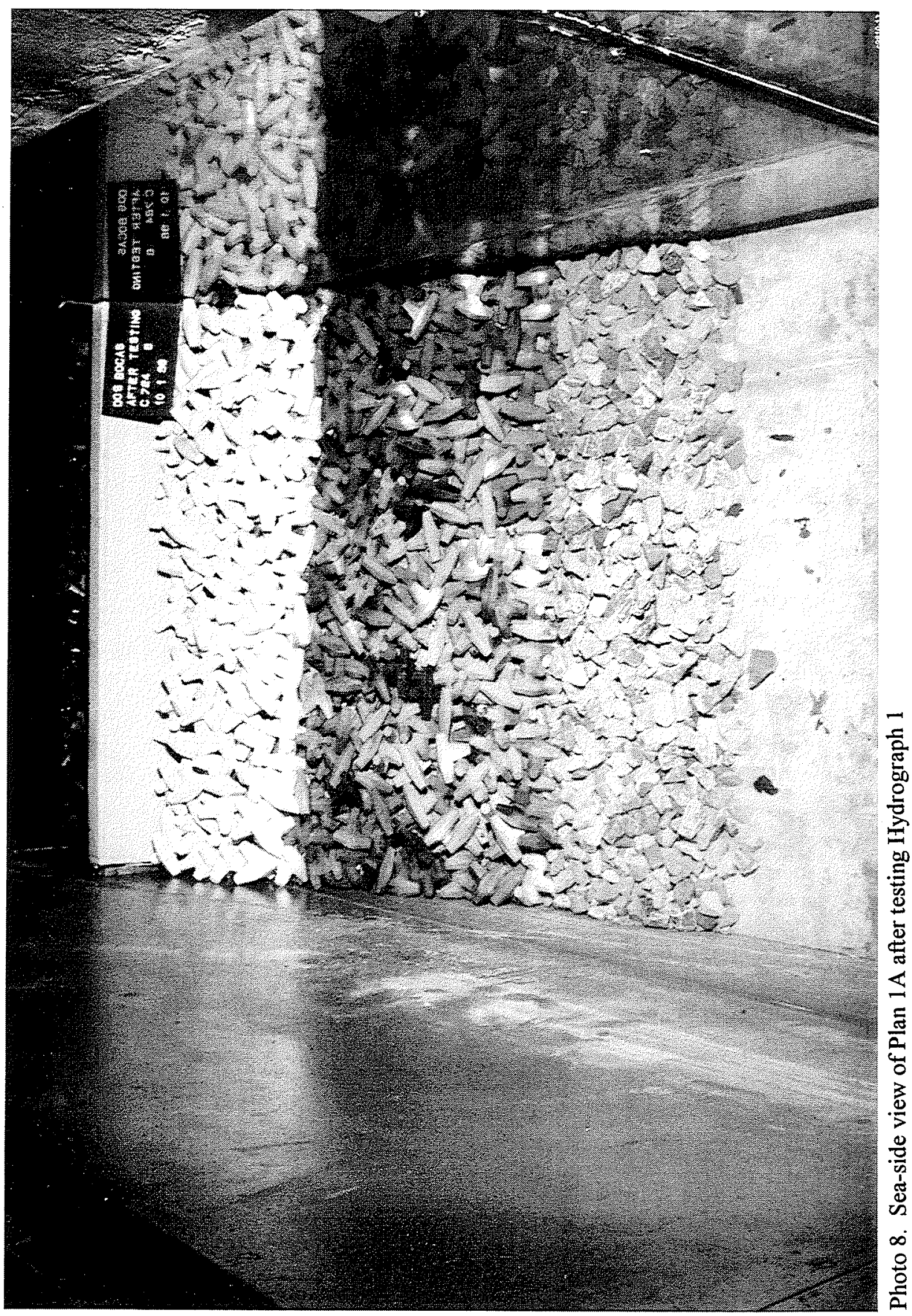




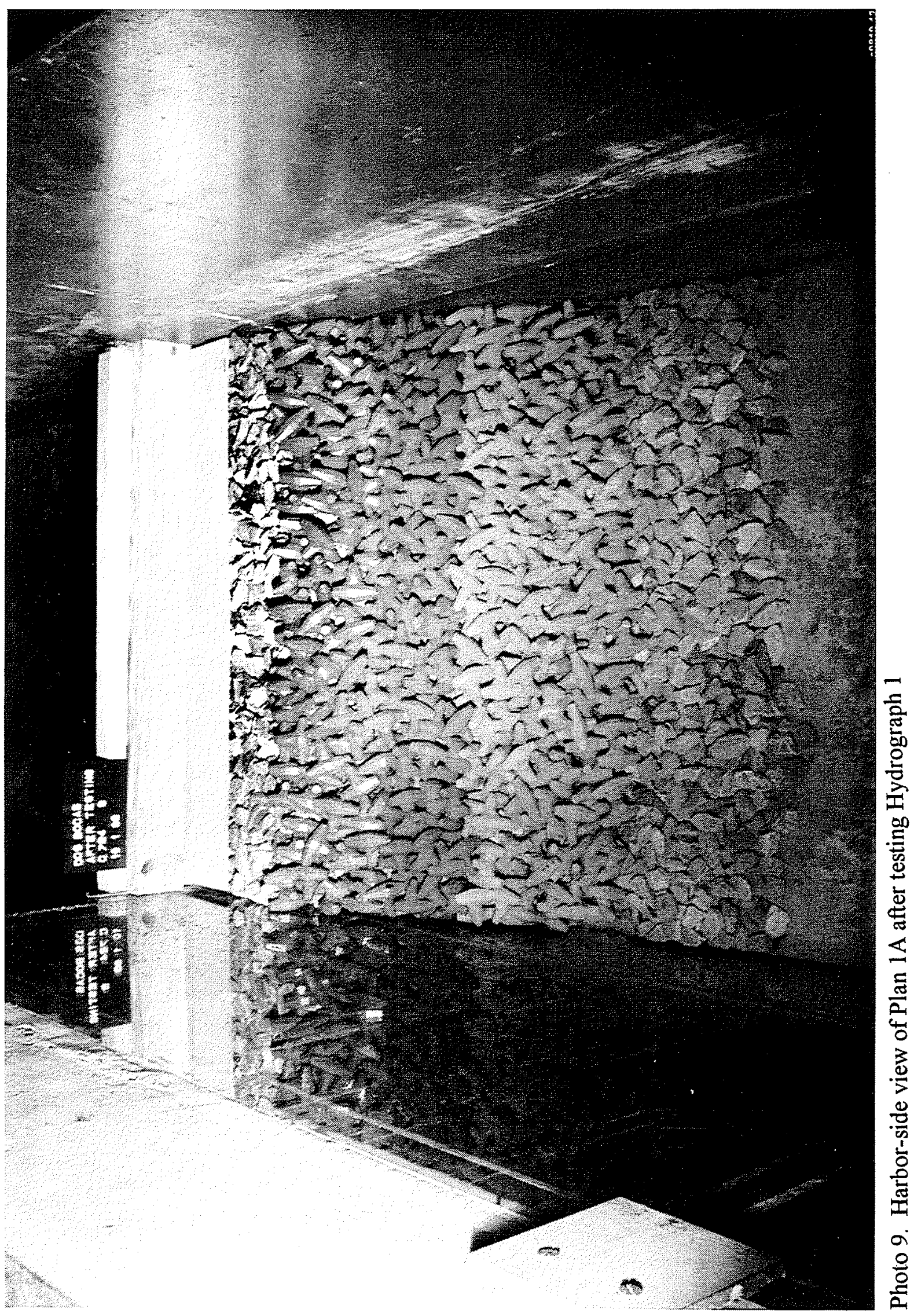



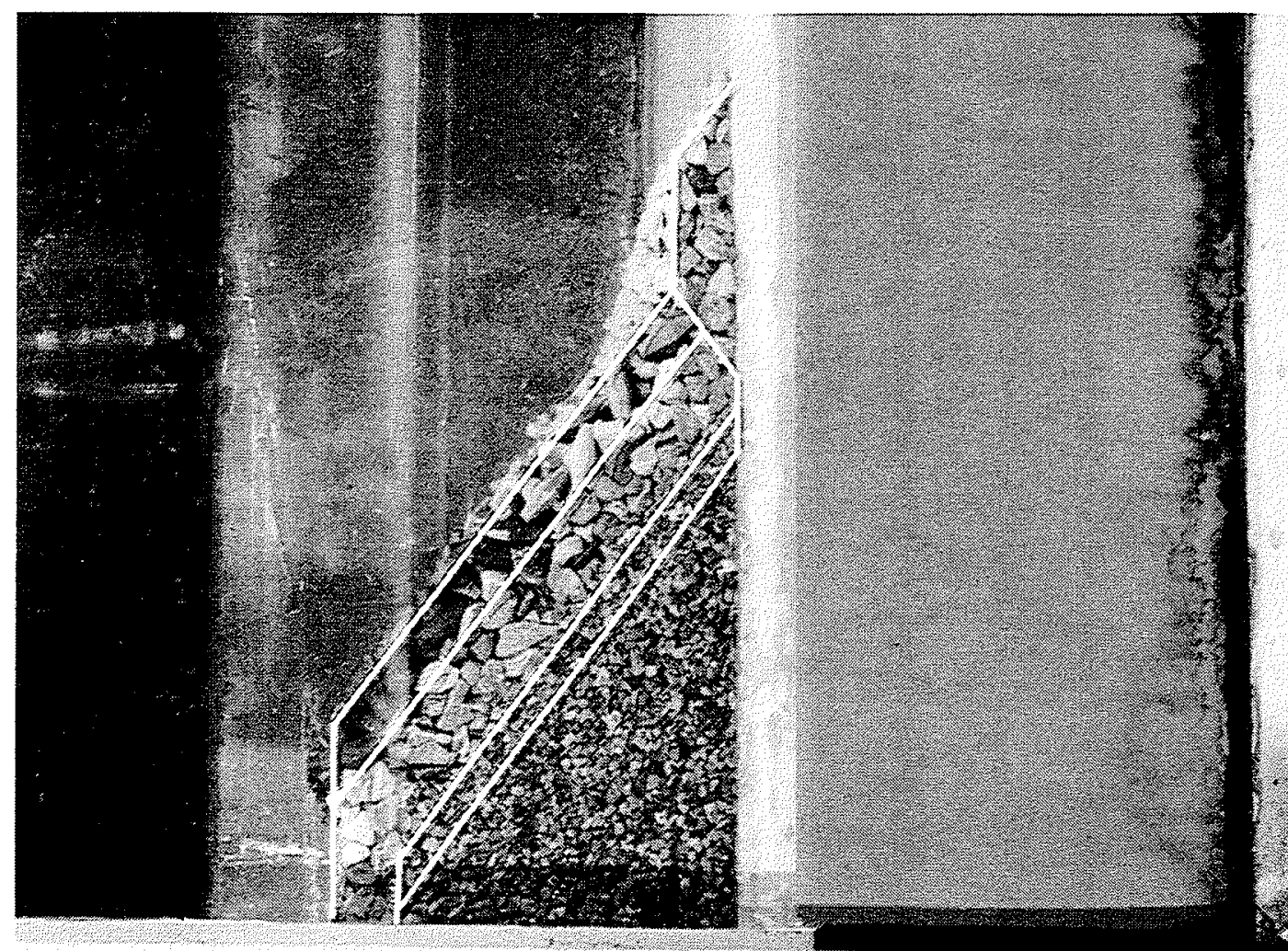

总

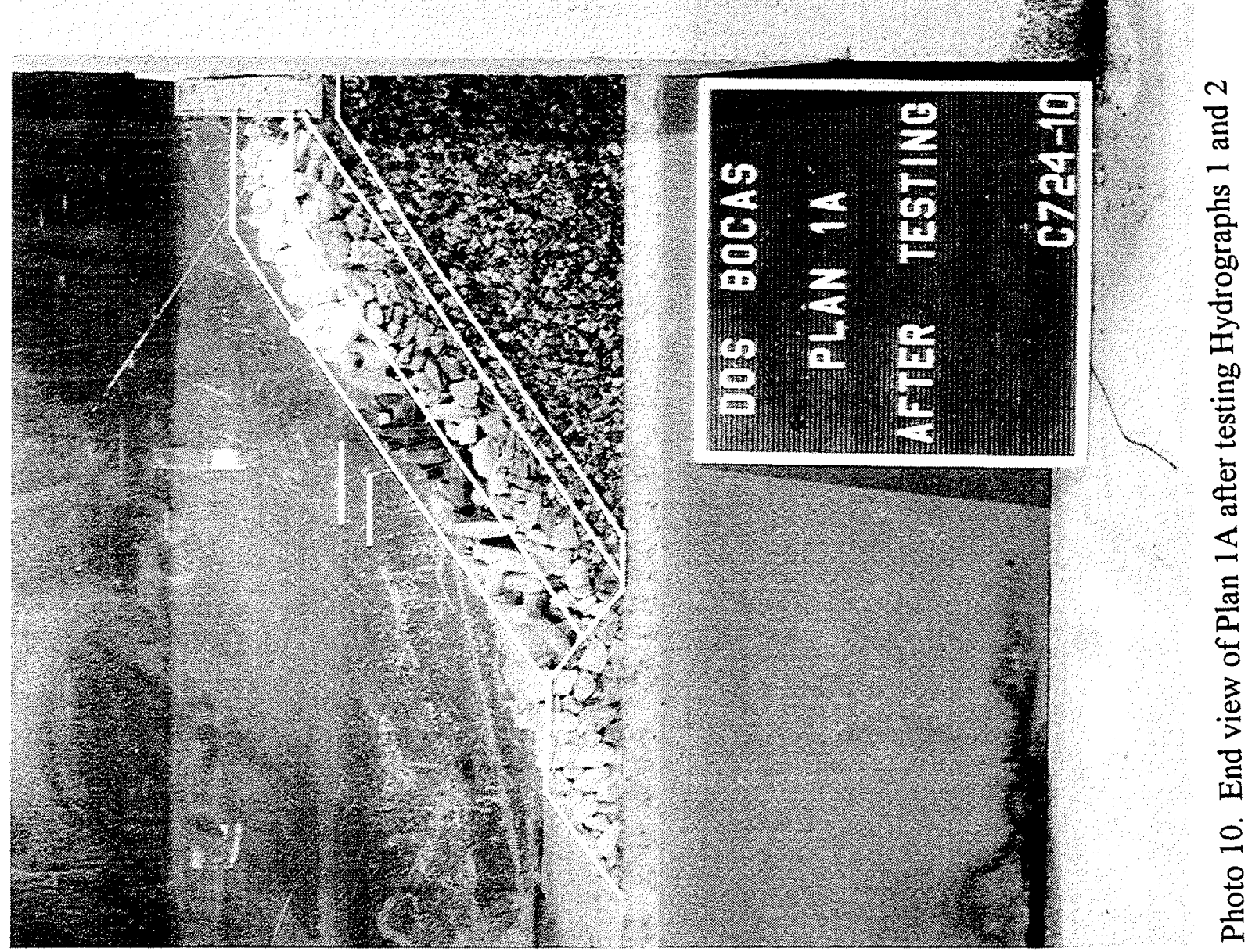




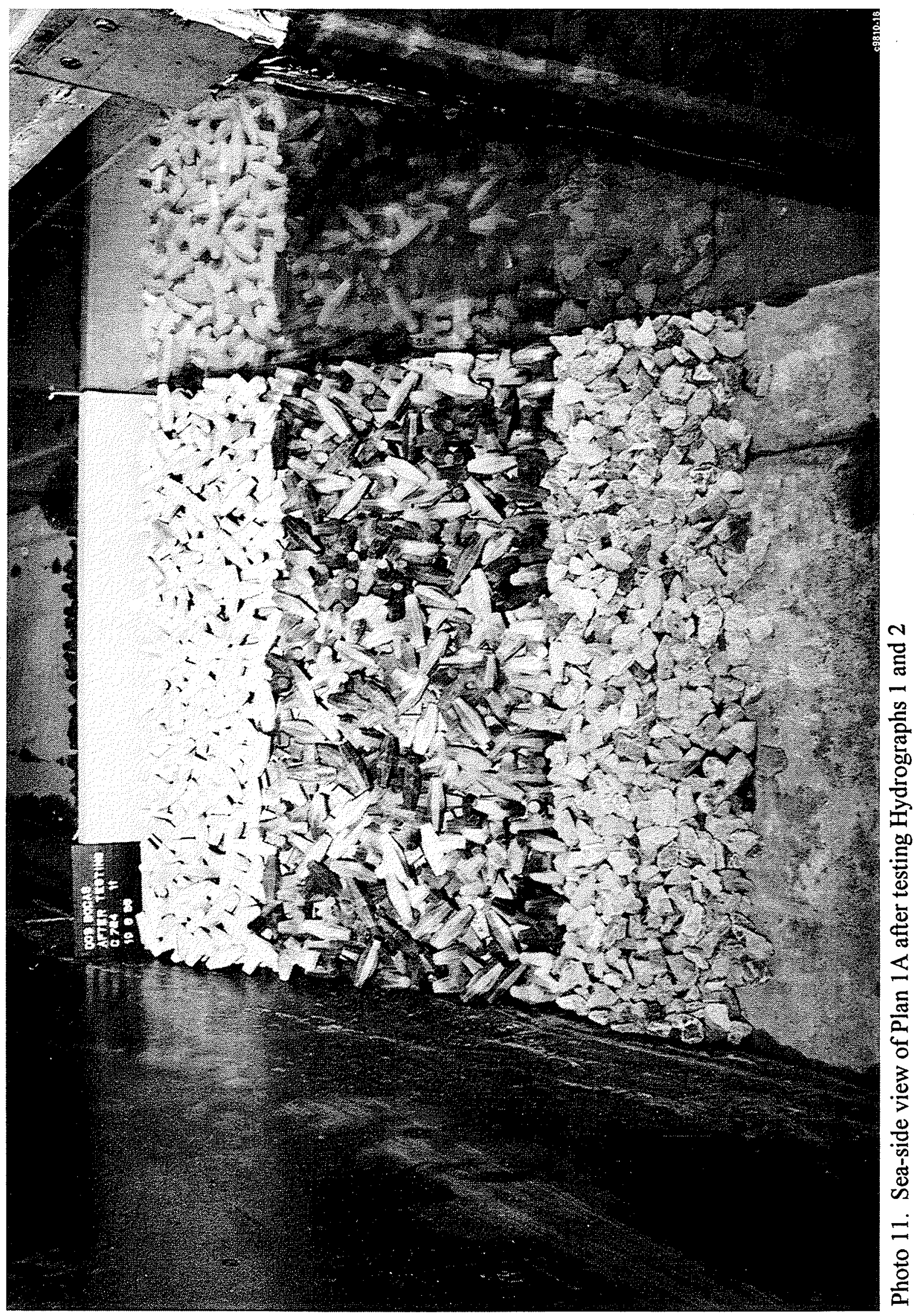




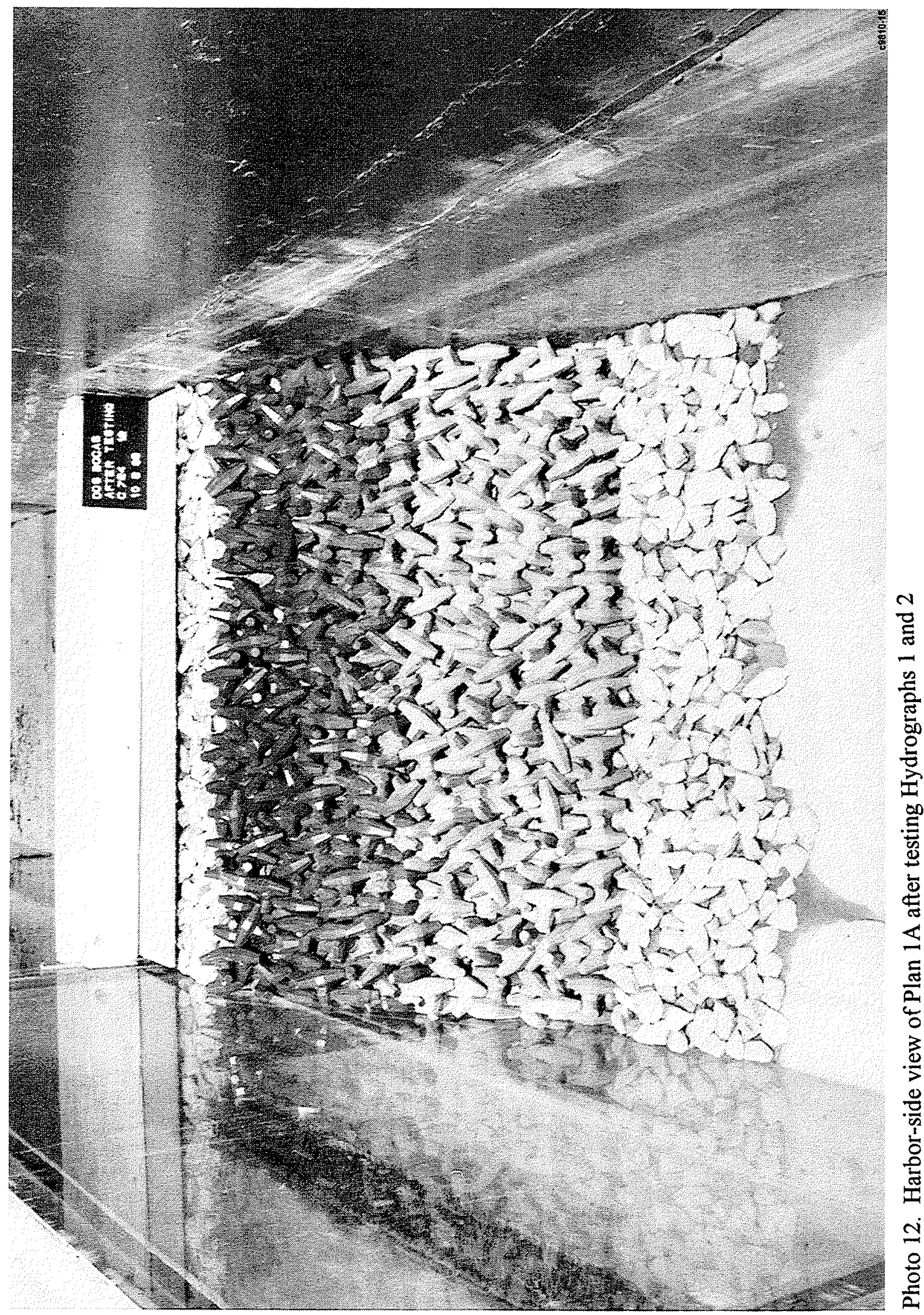



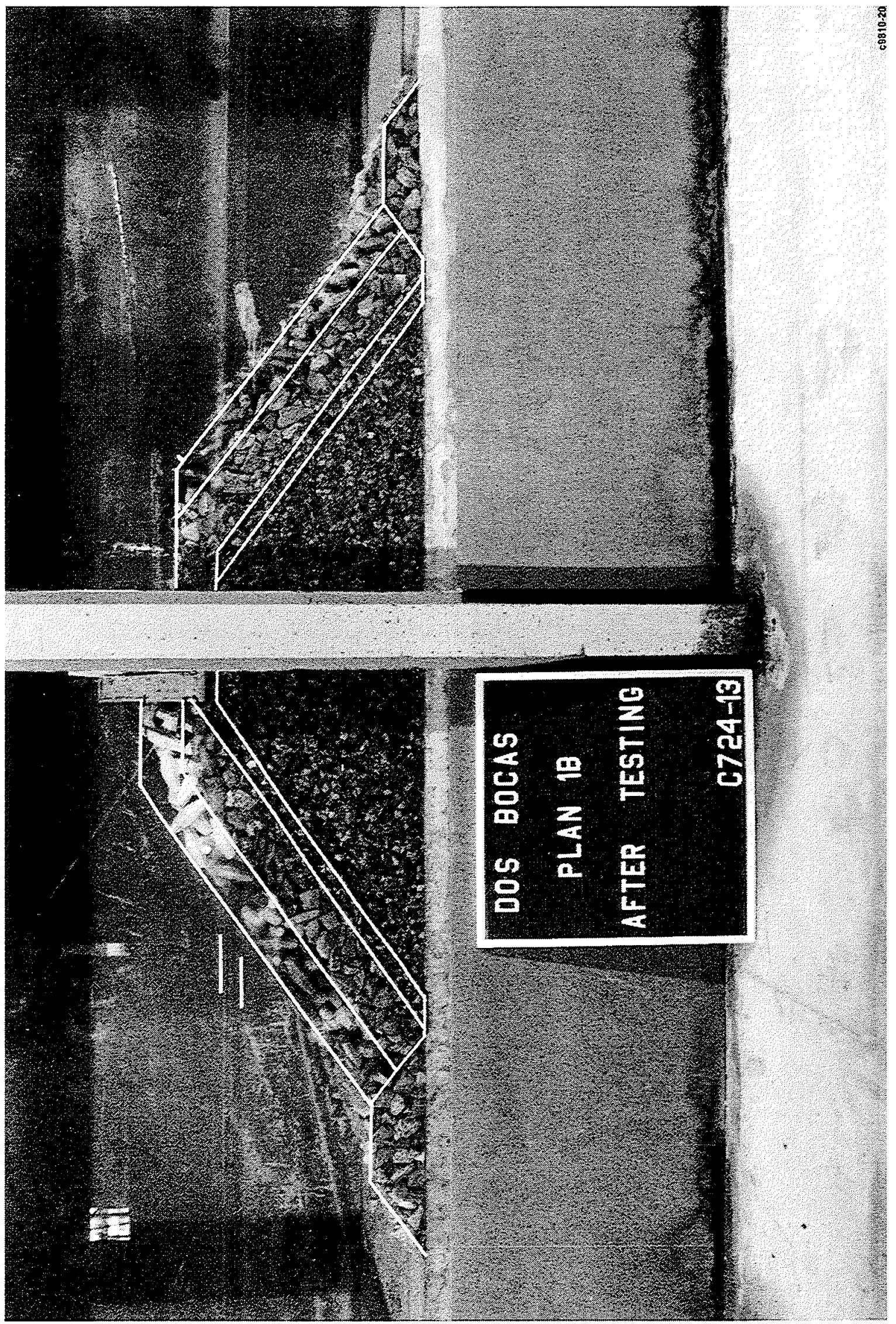

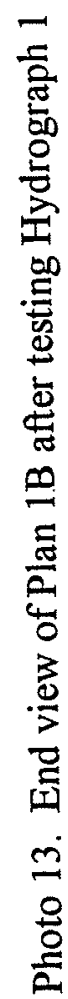




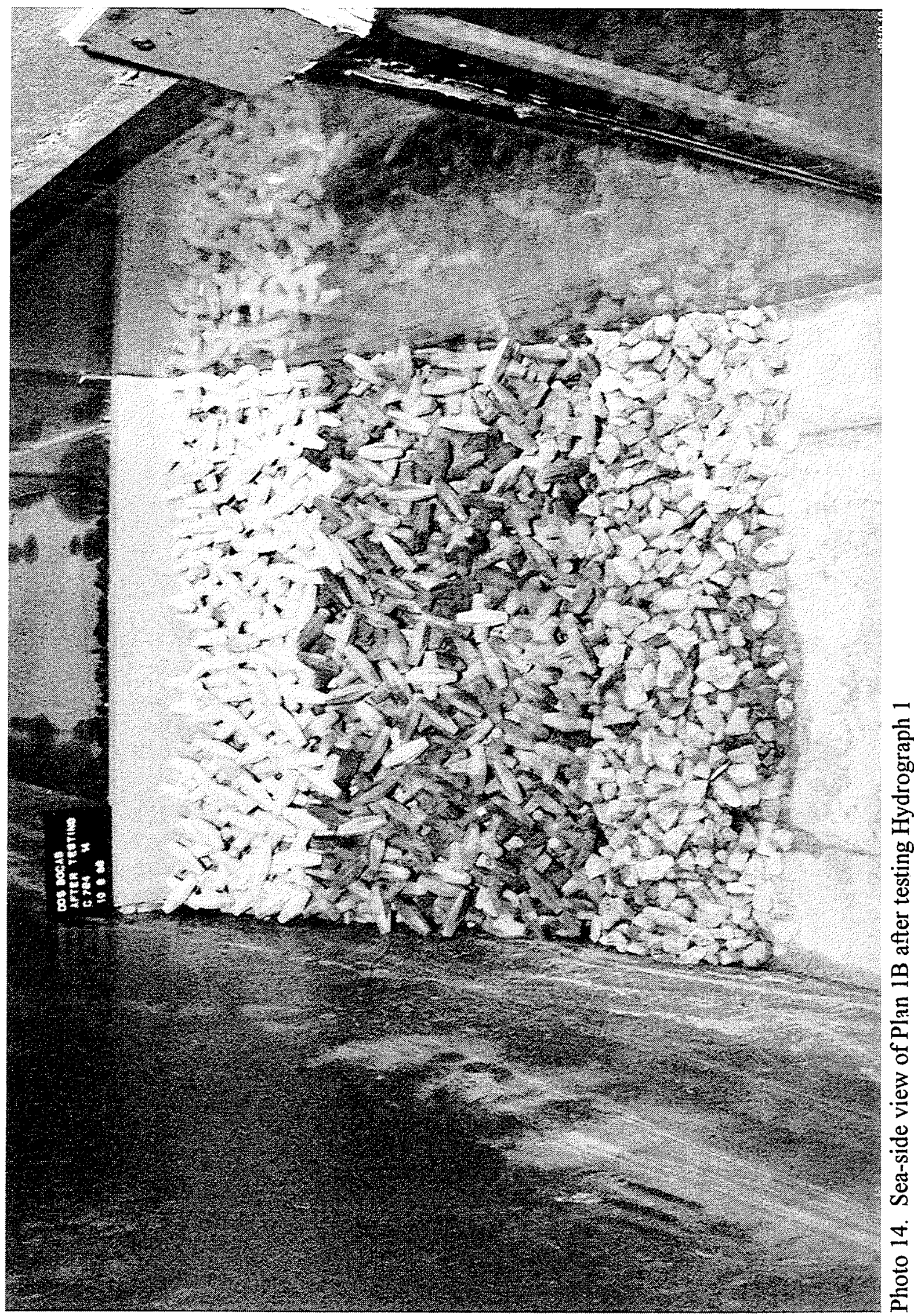




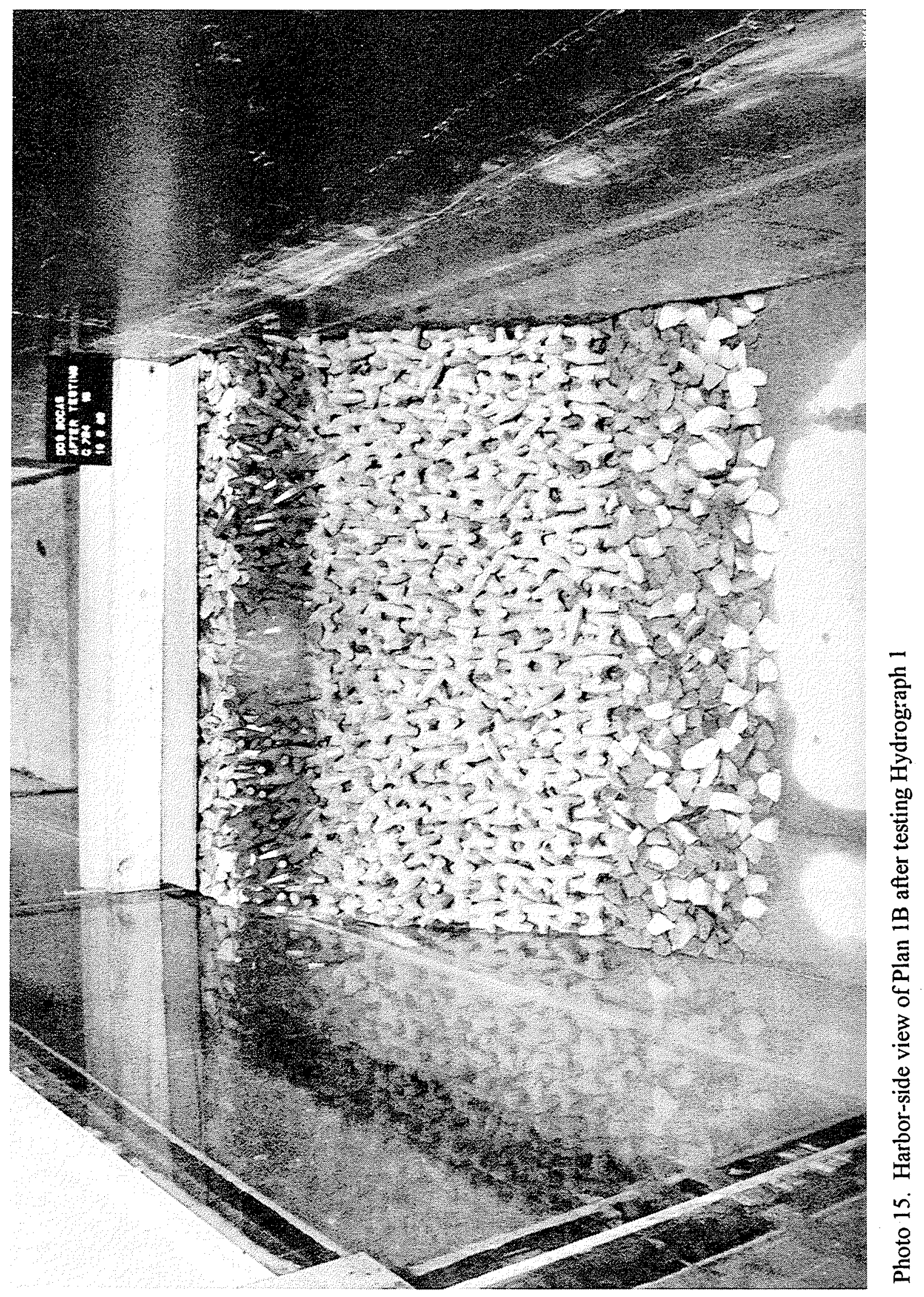



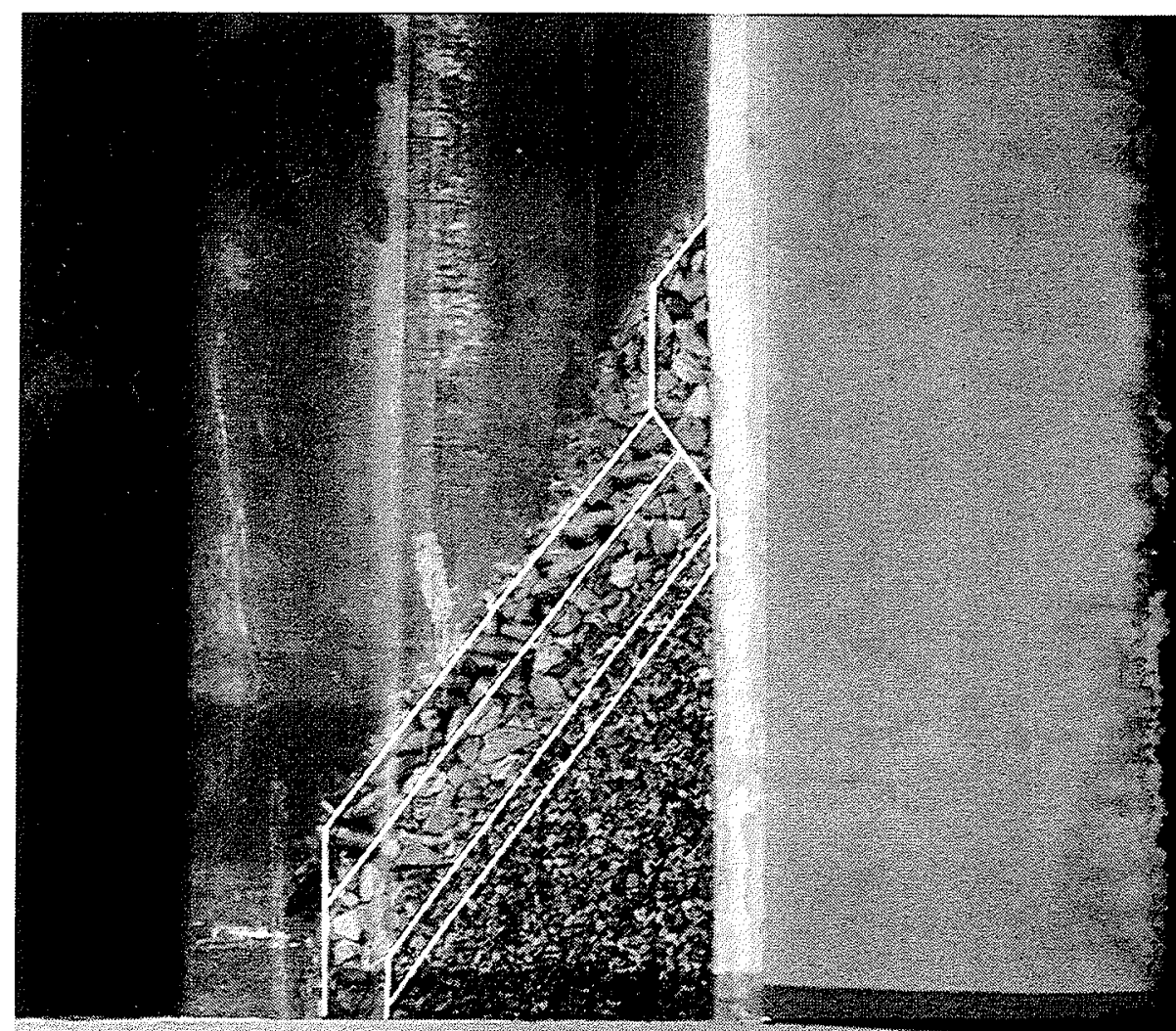

홍

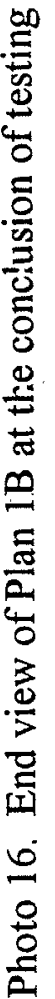




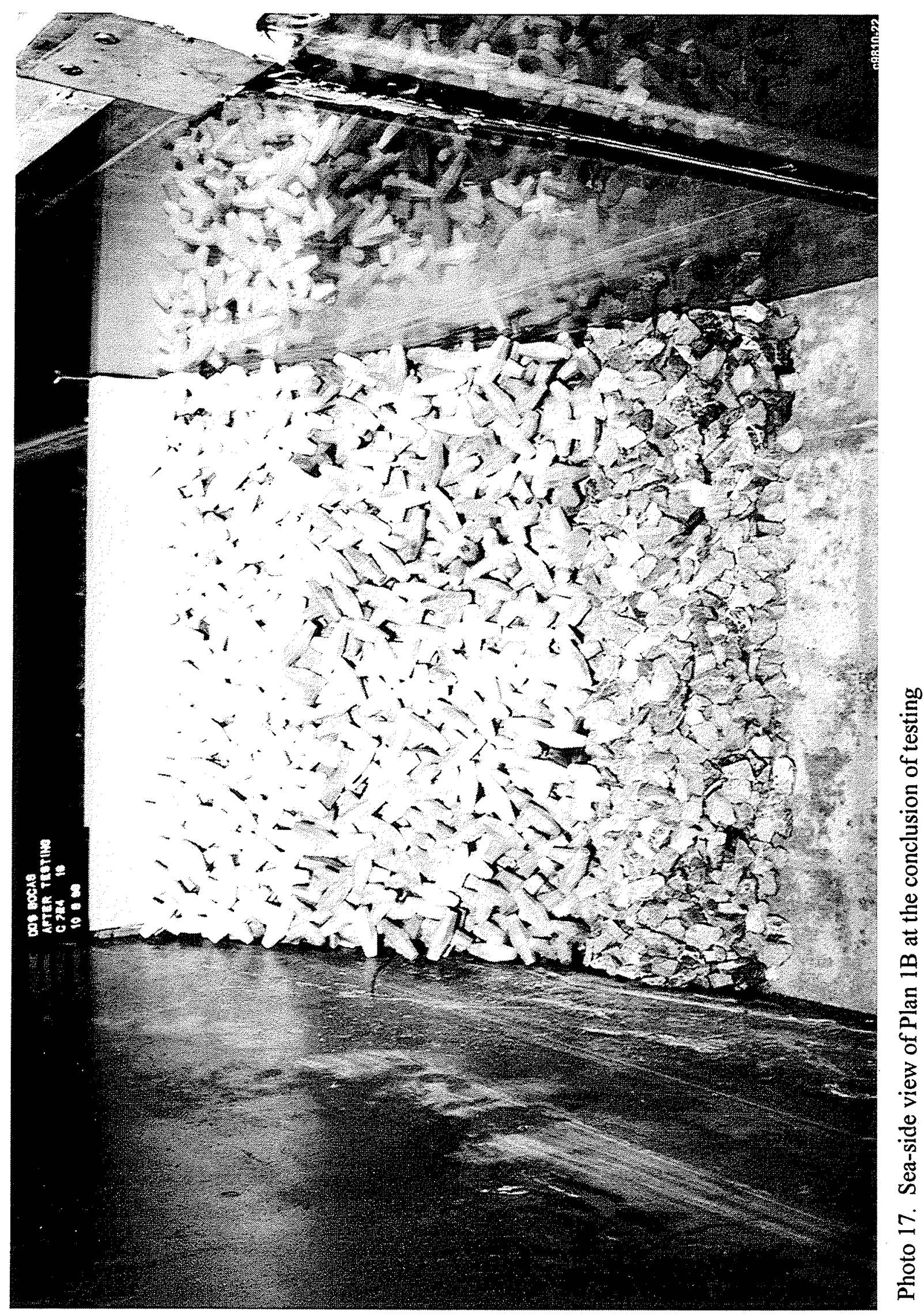




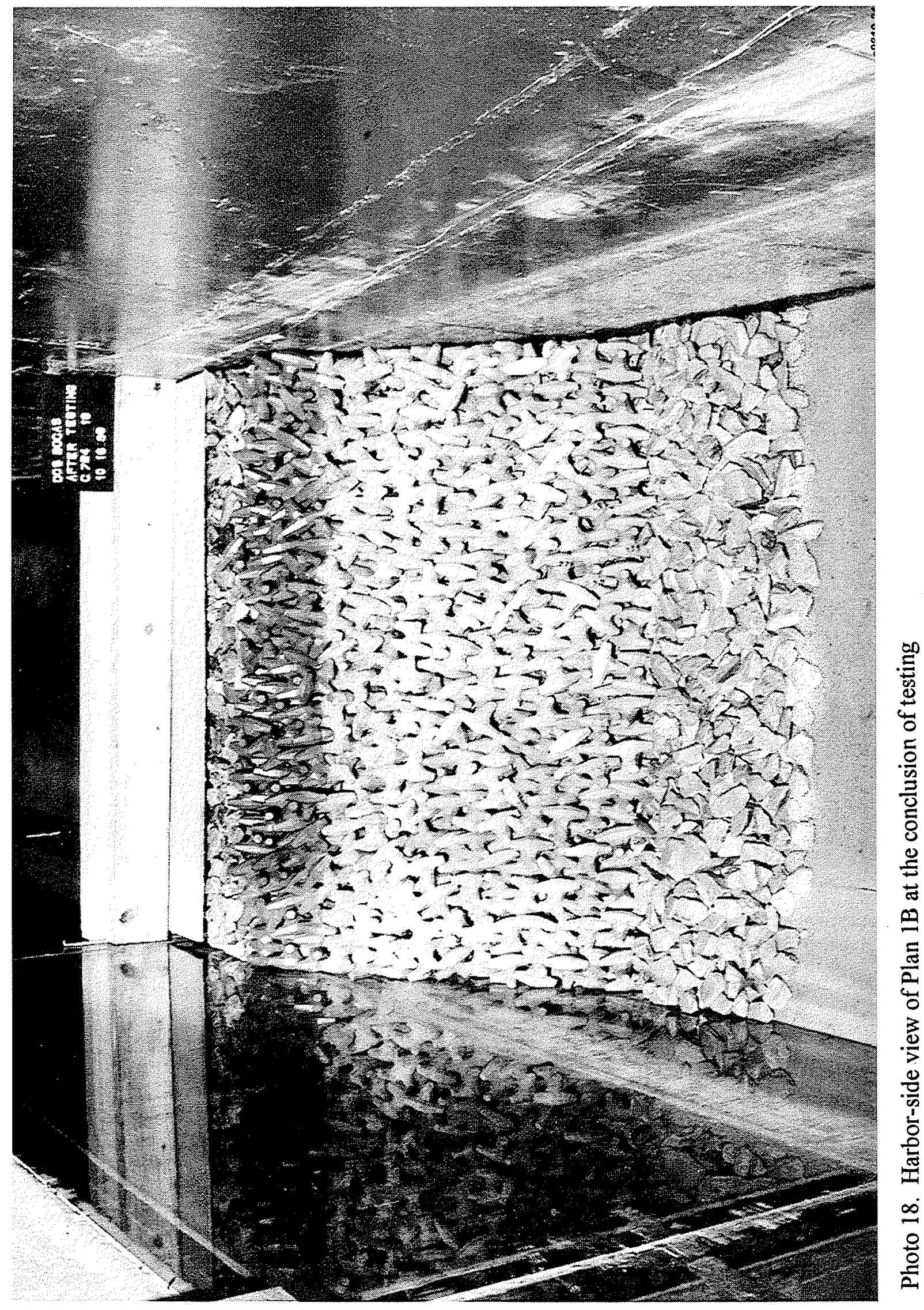



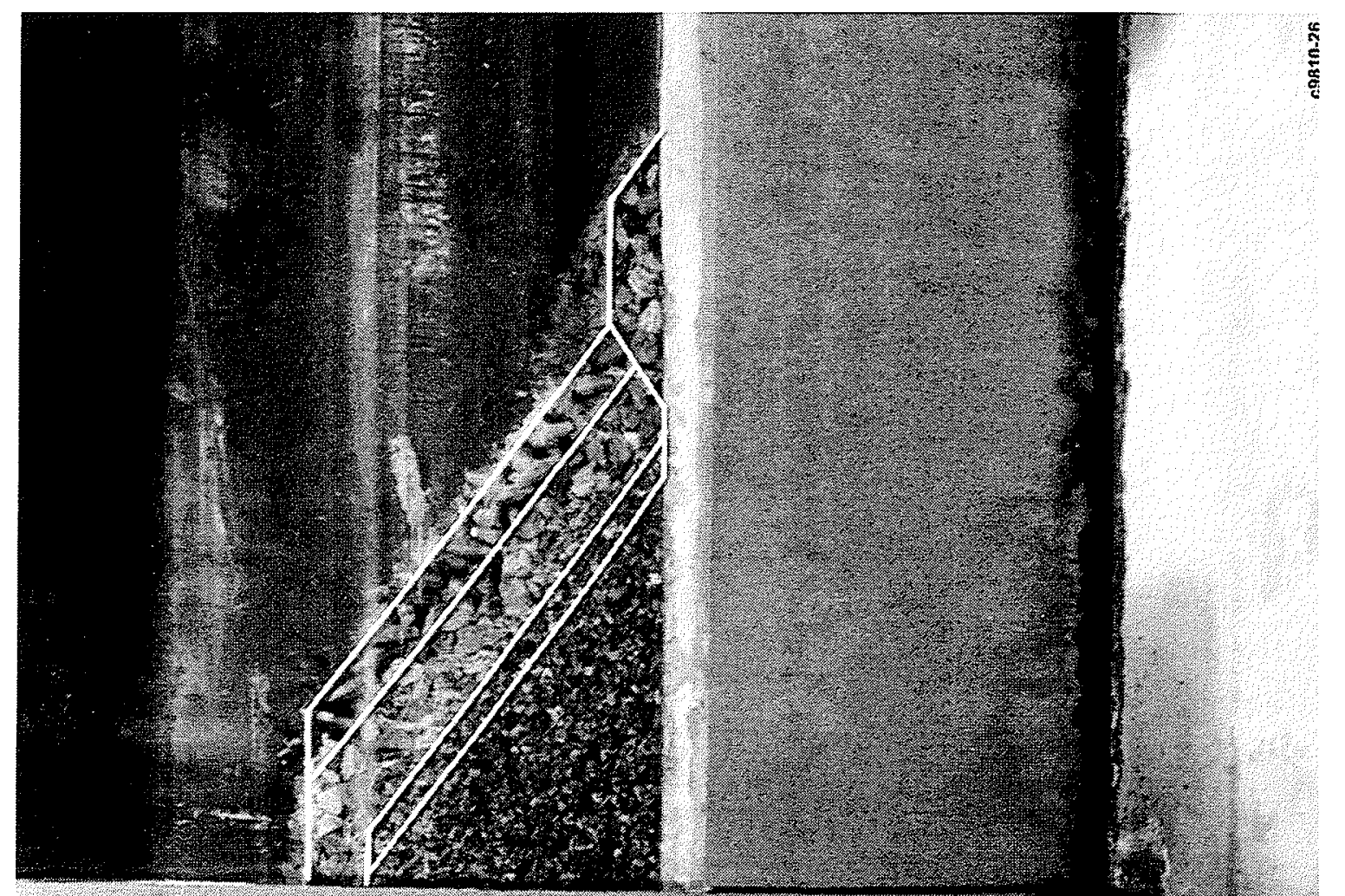

है

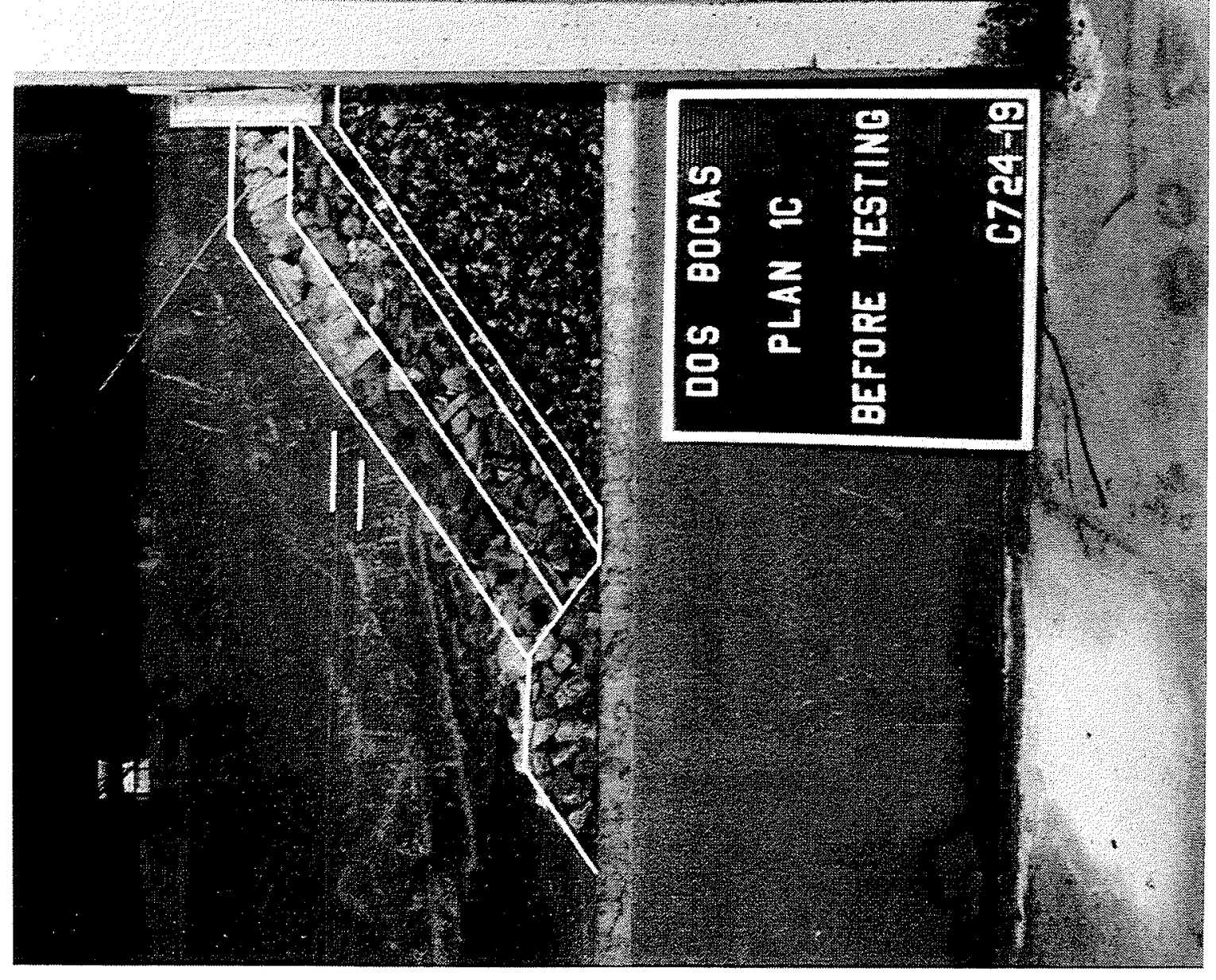

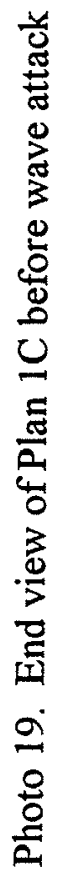




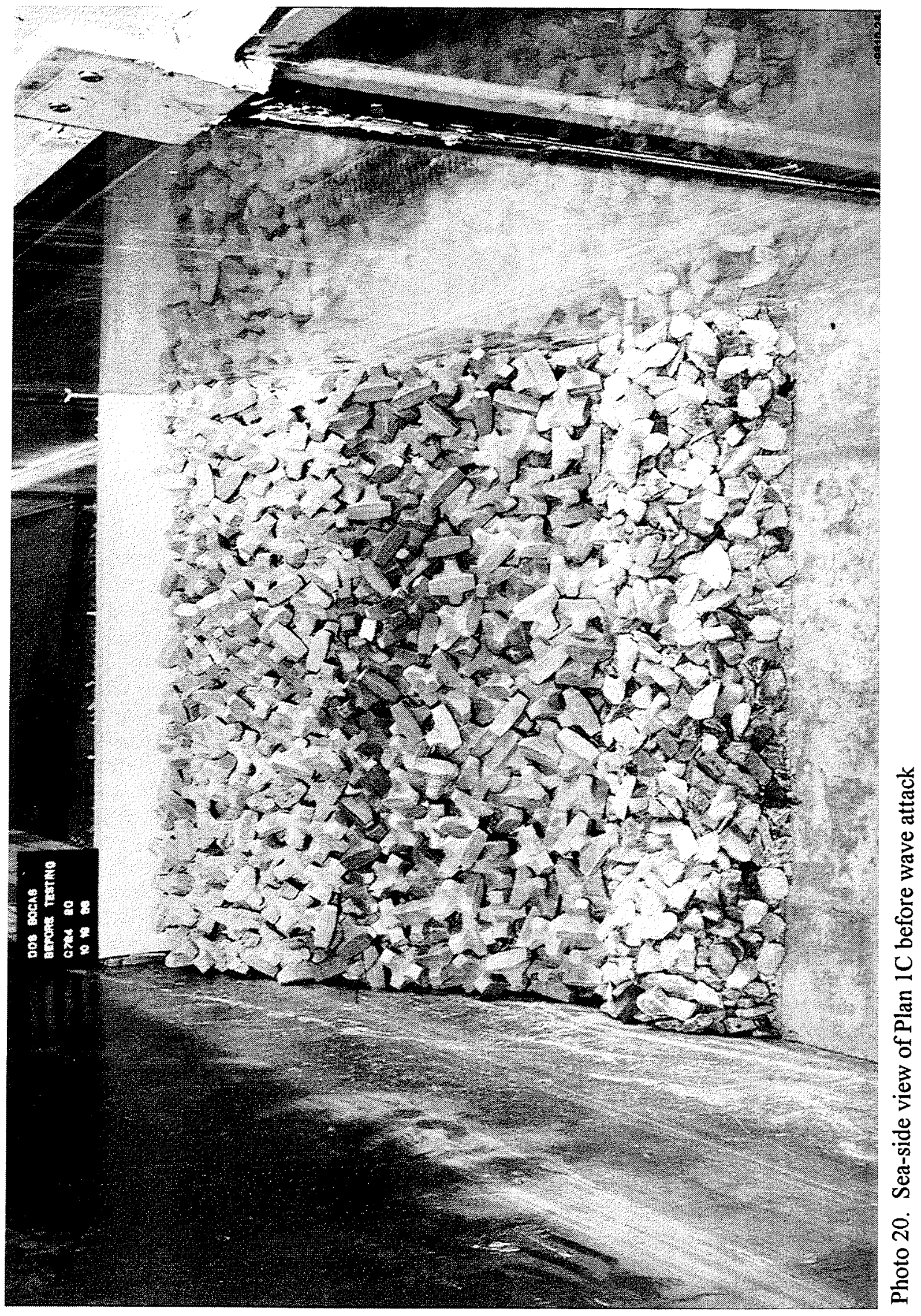




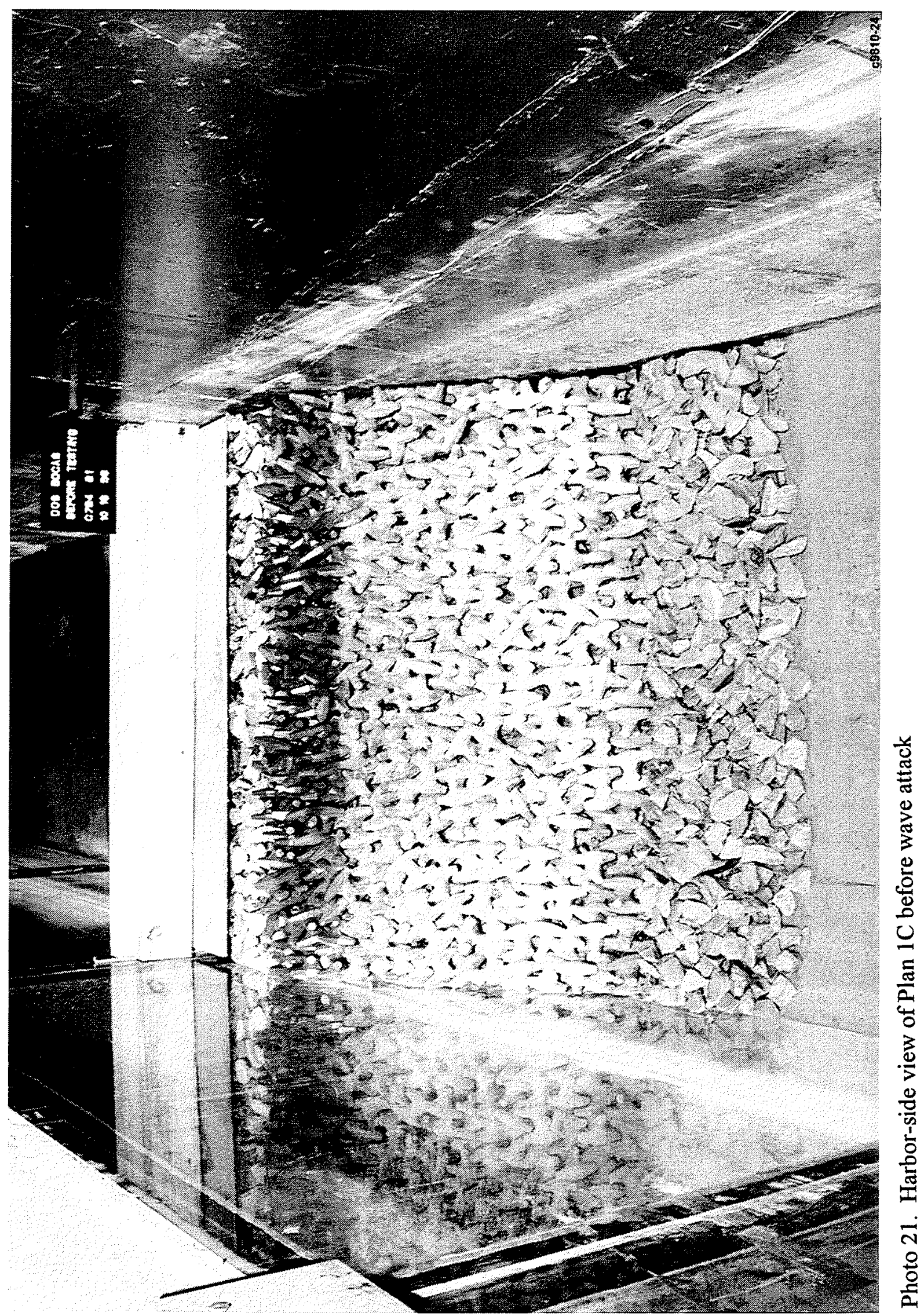



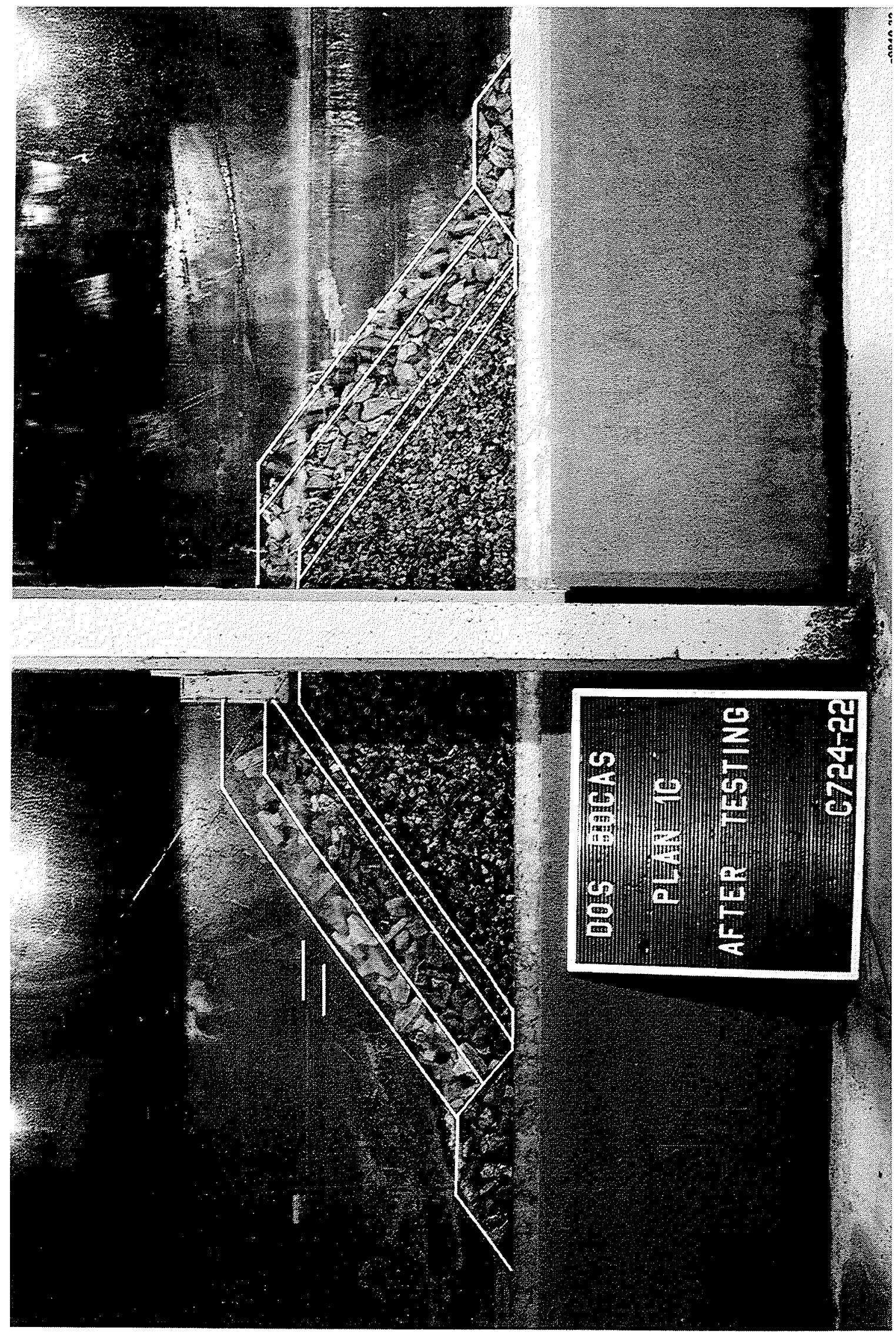

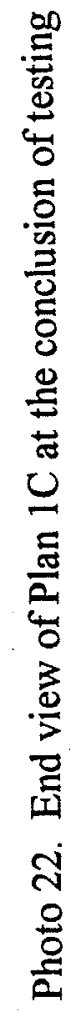



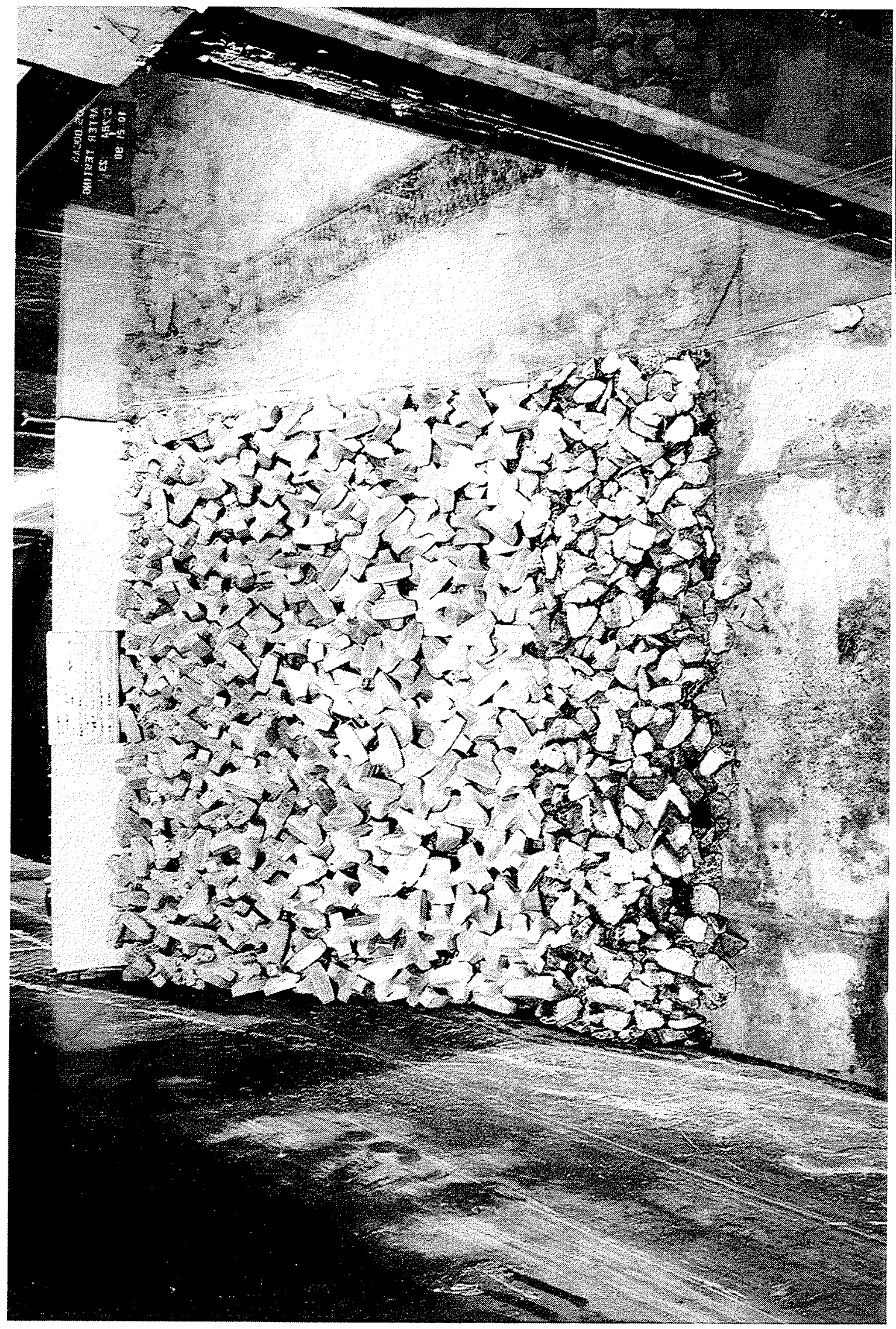

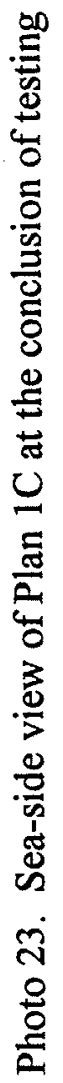




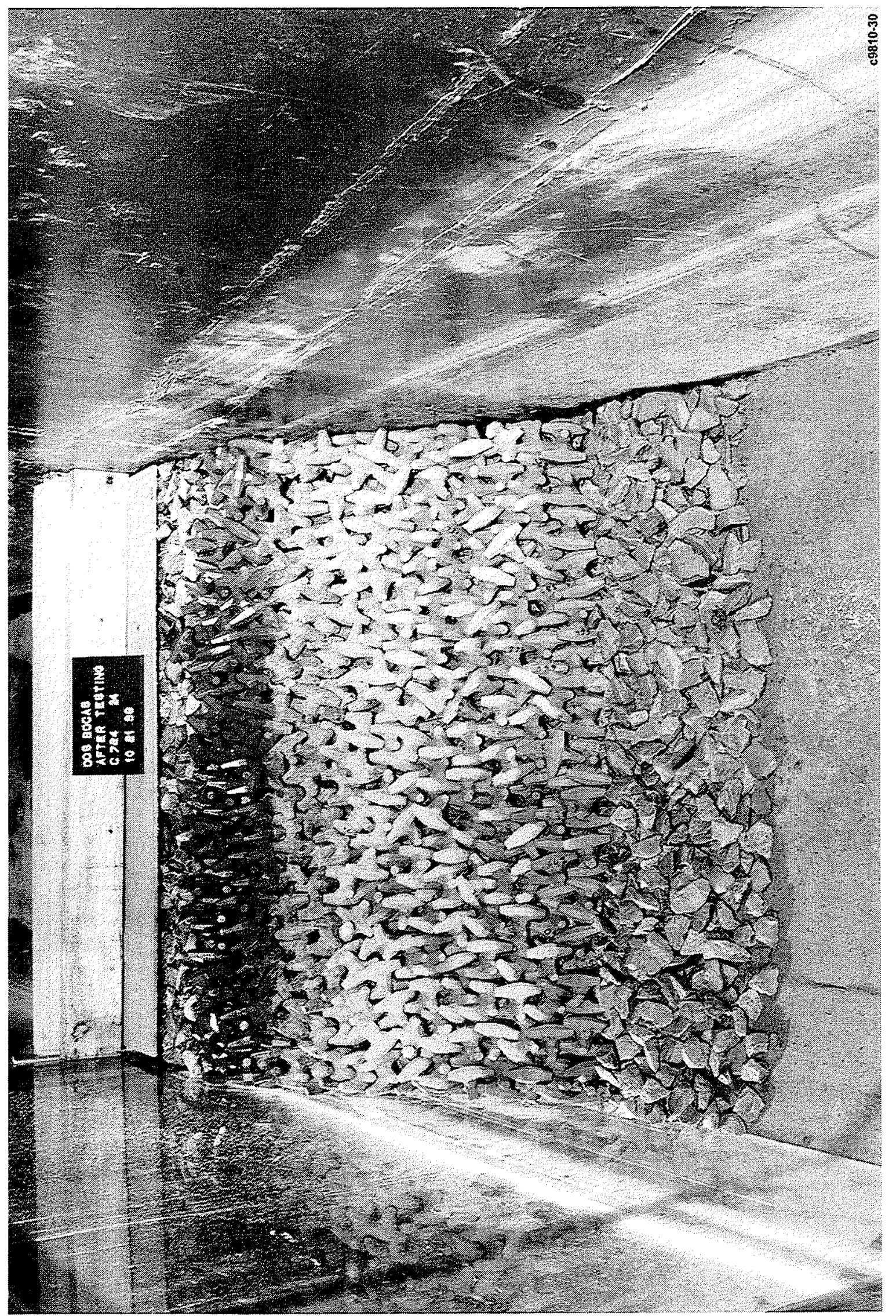

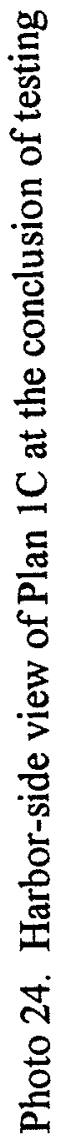




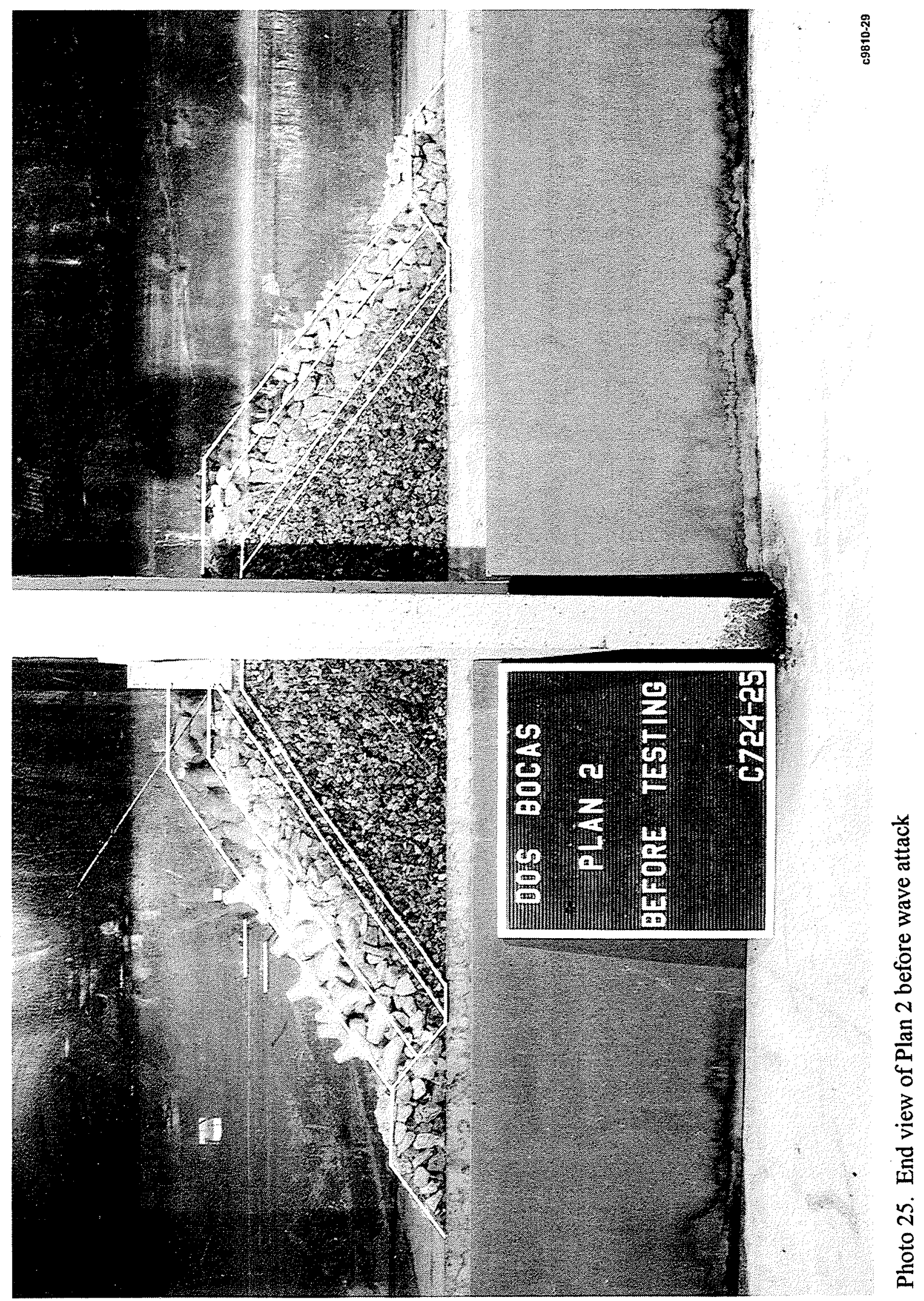




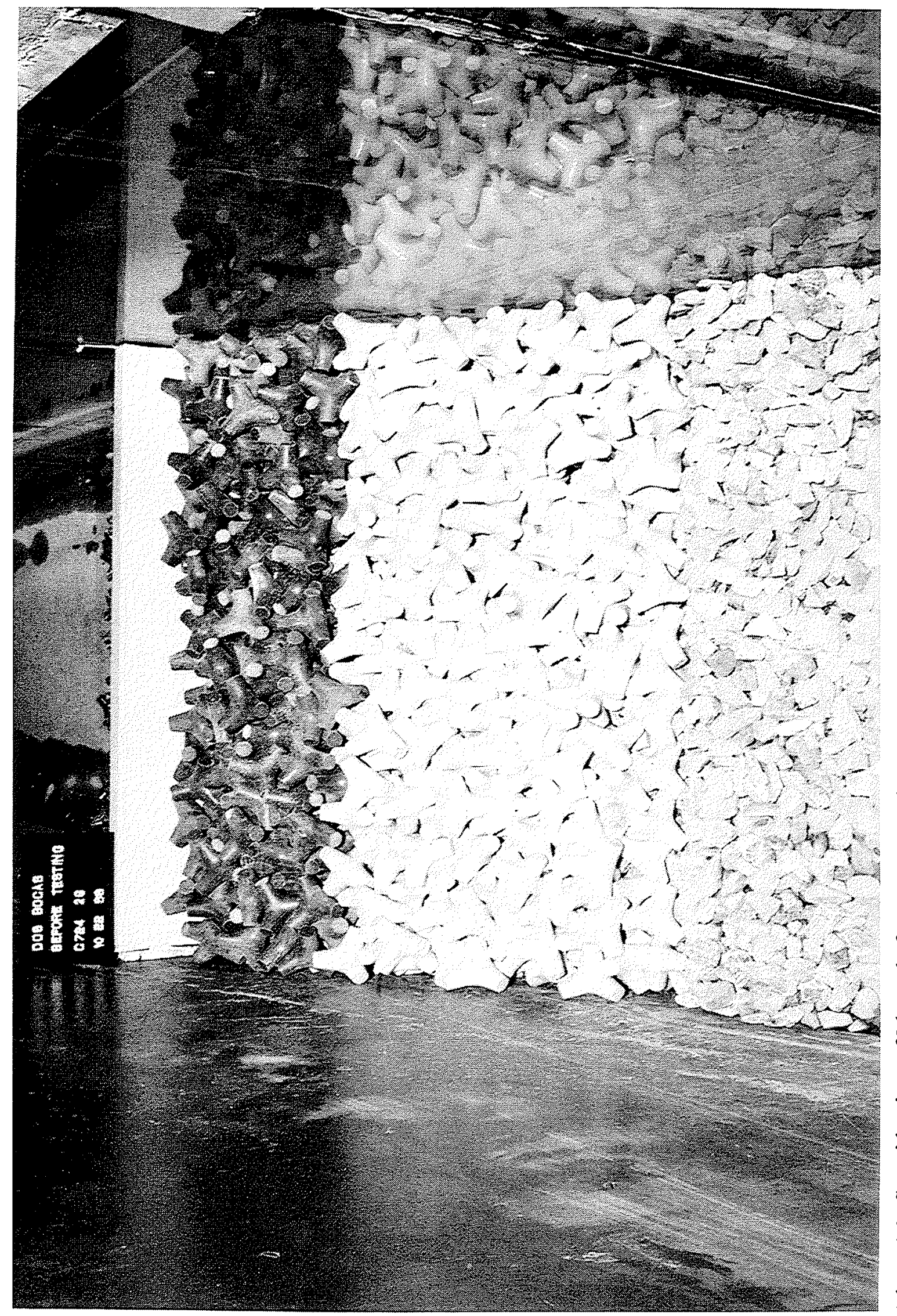

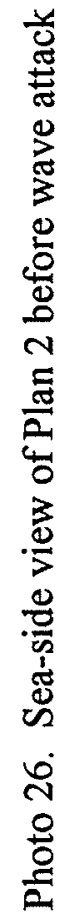




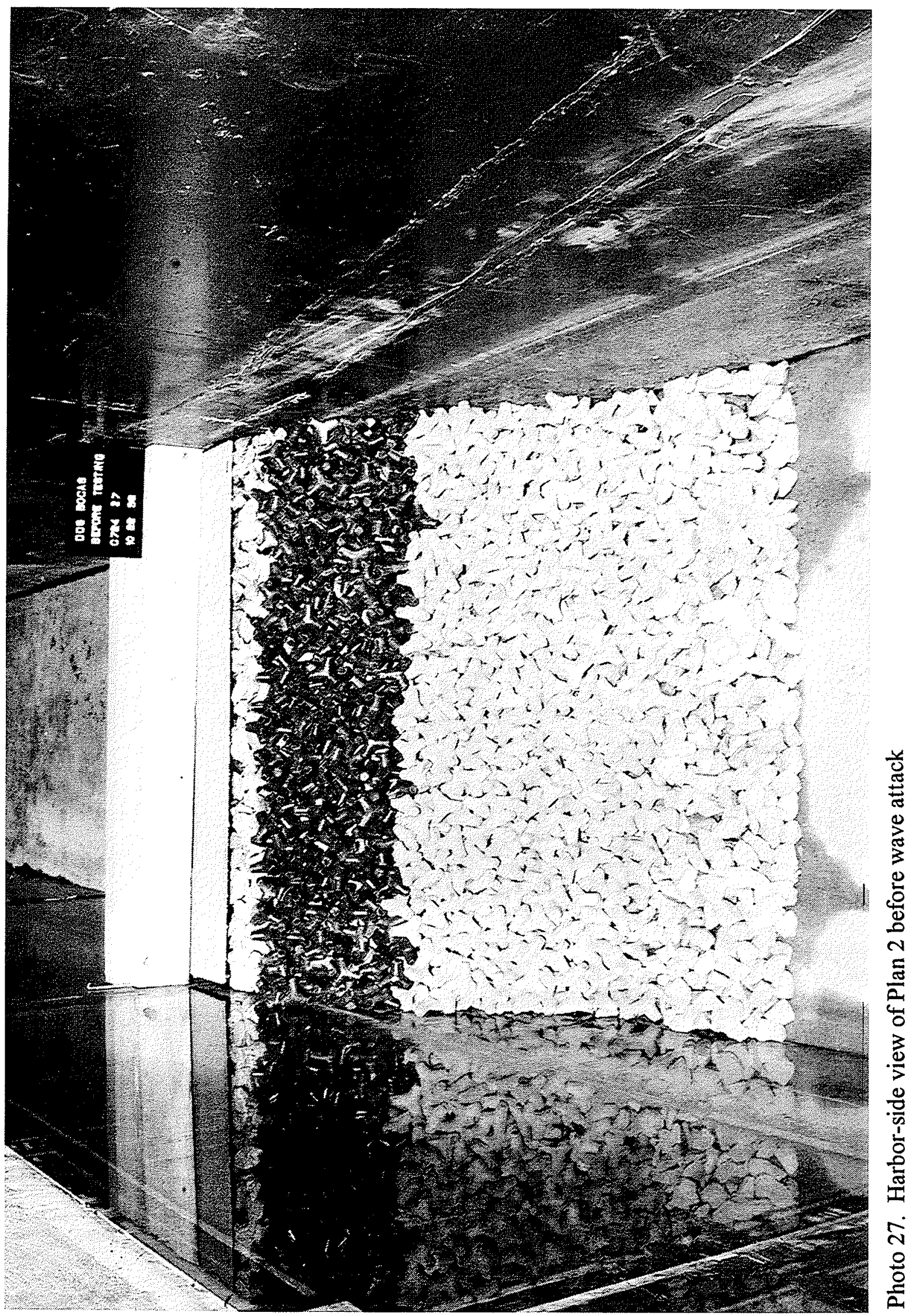



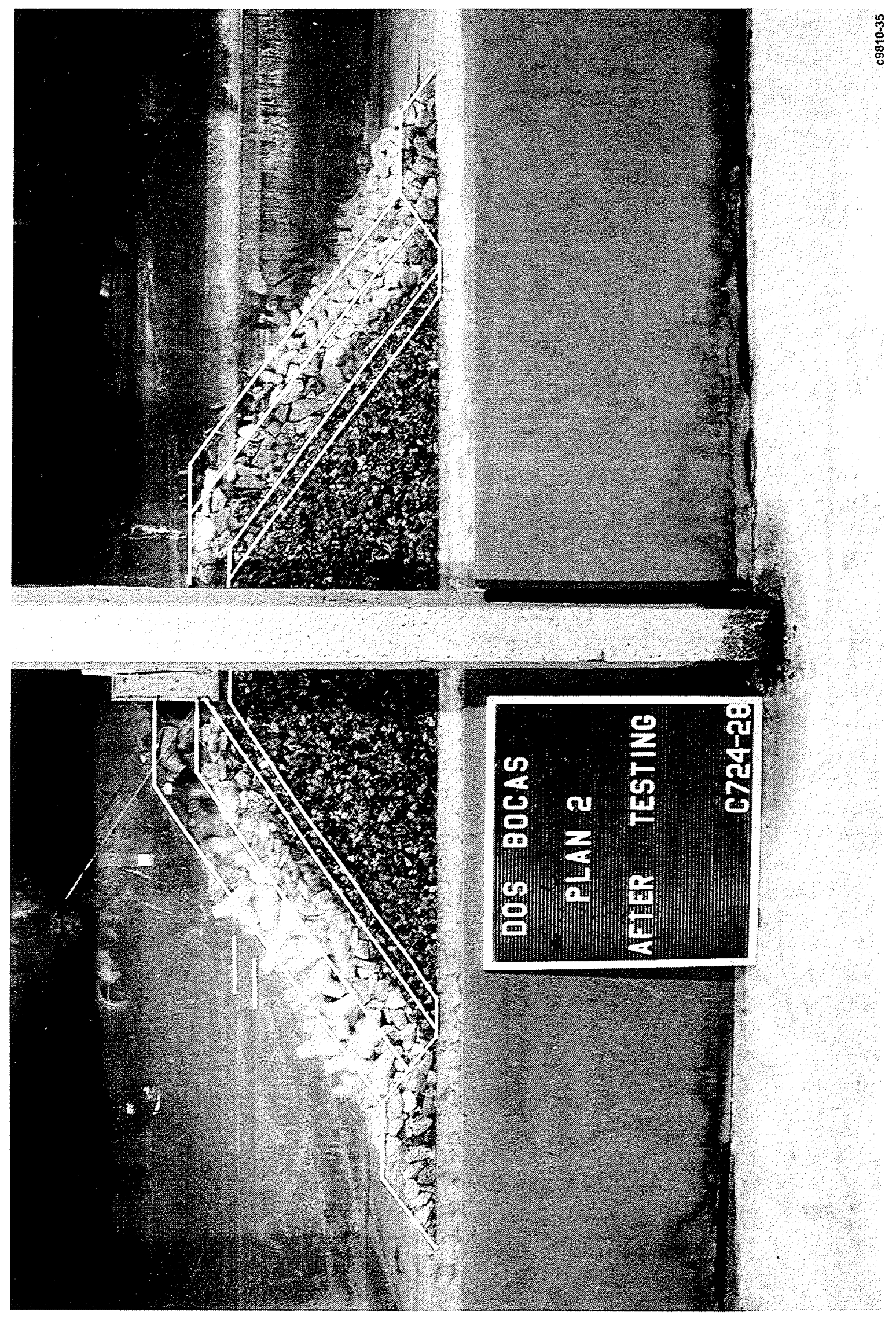

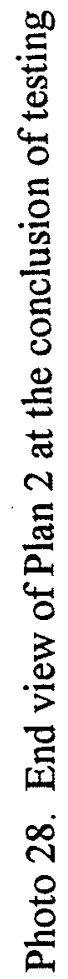




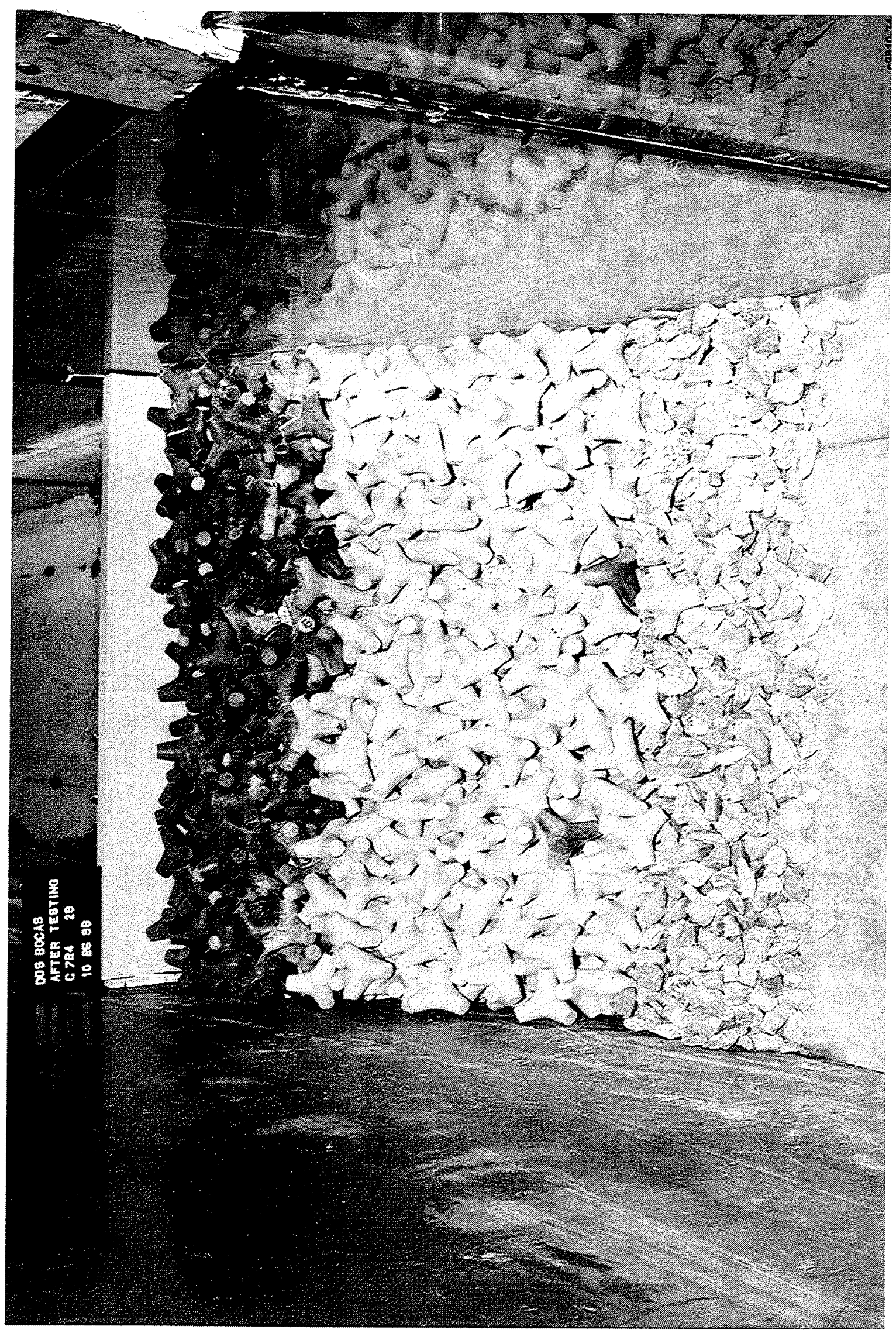

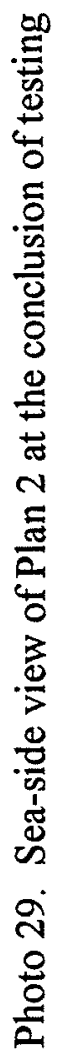




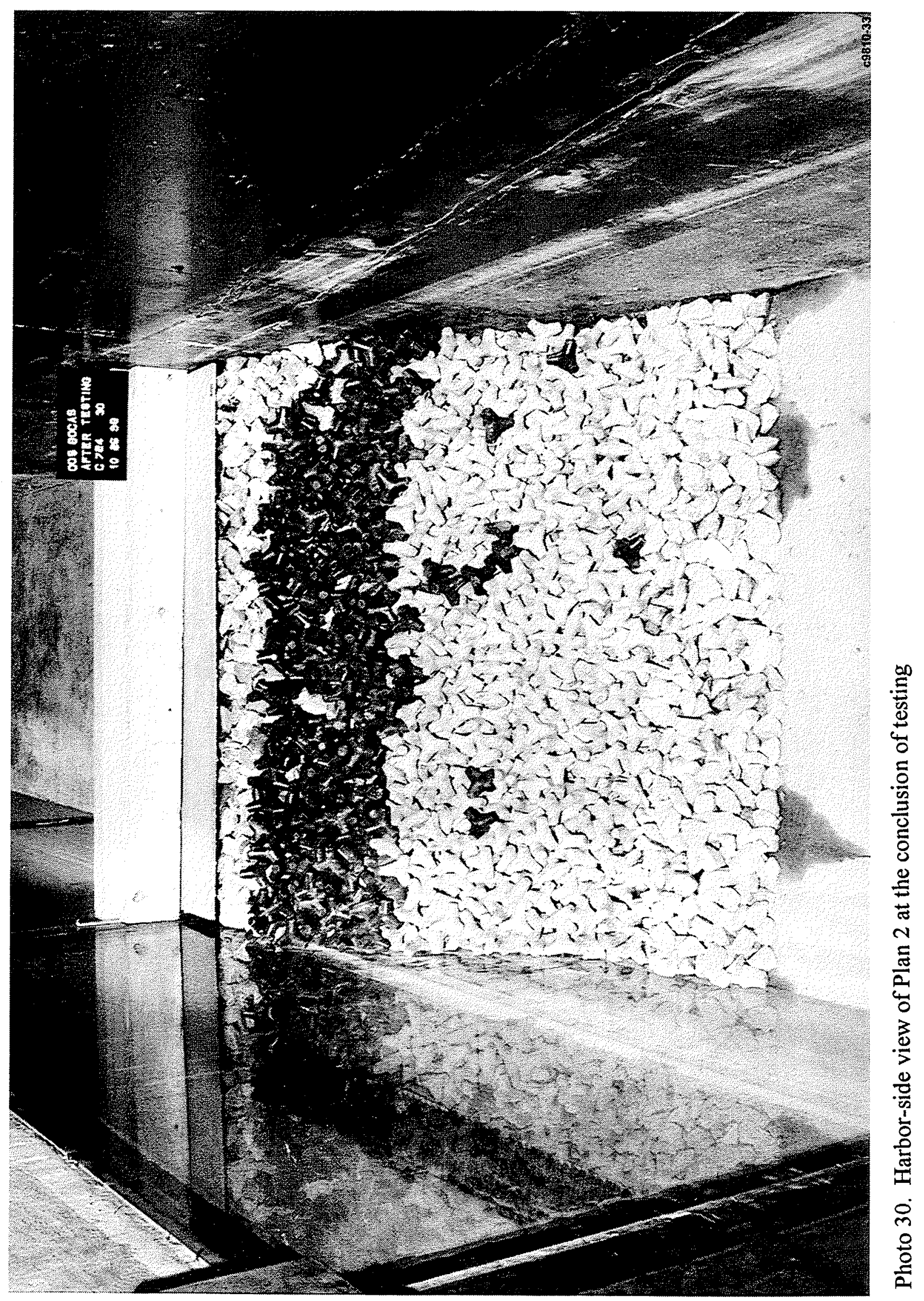




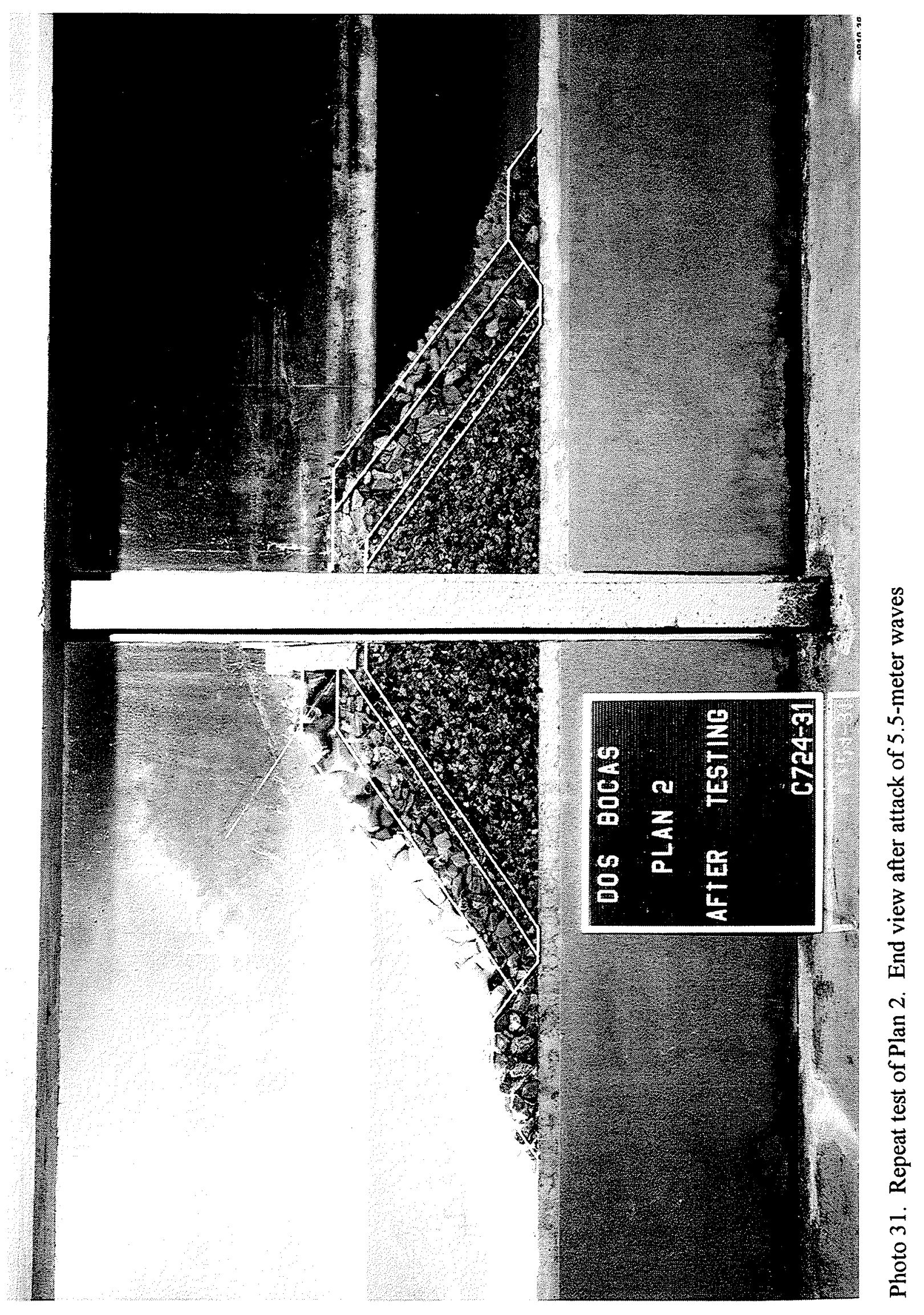




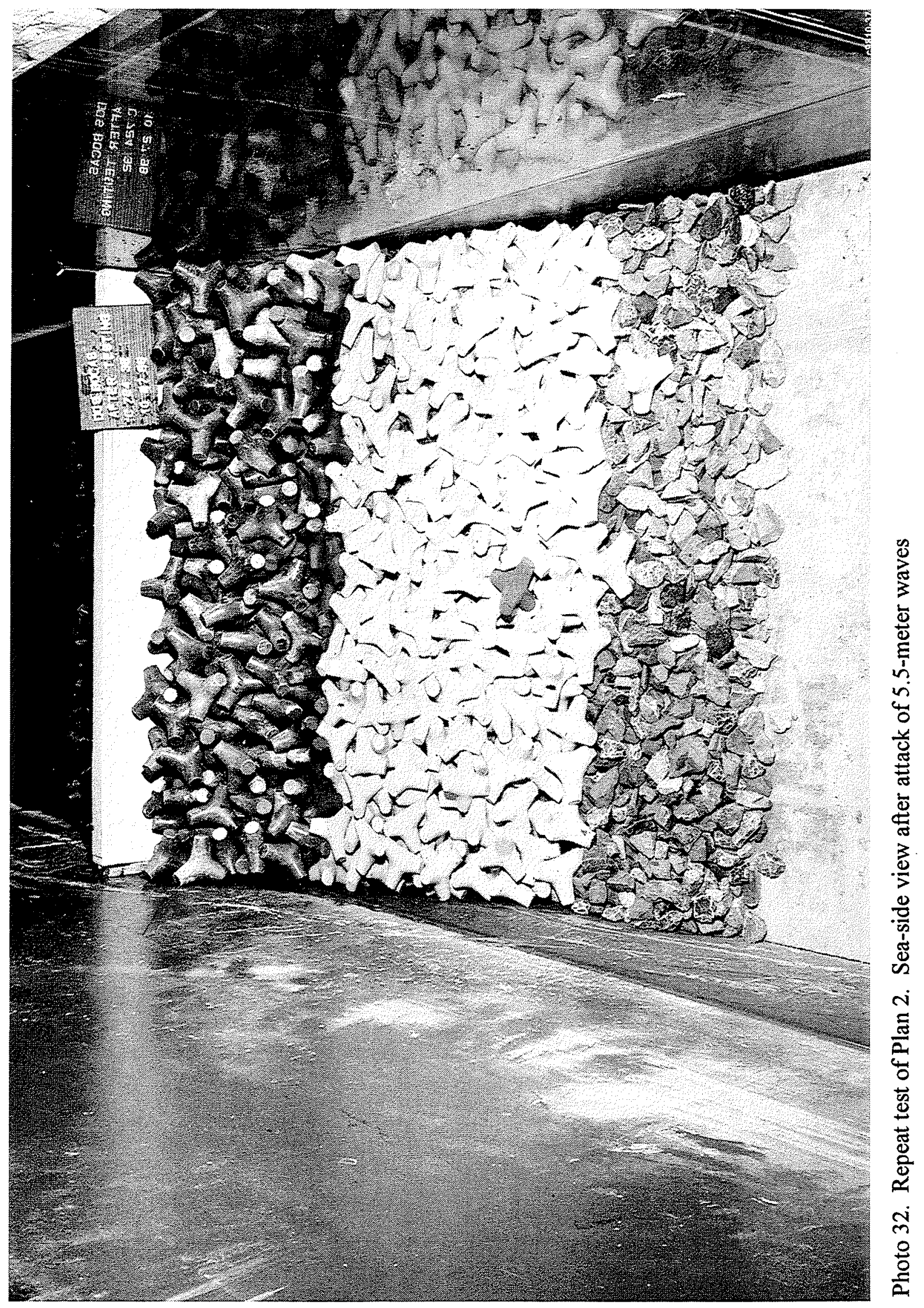




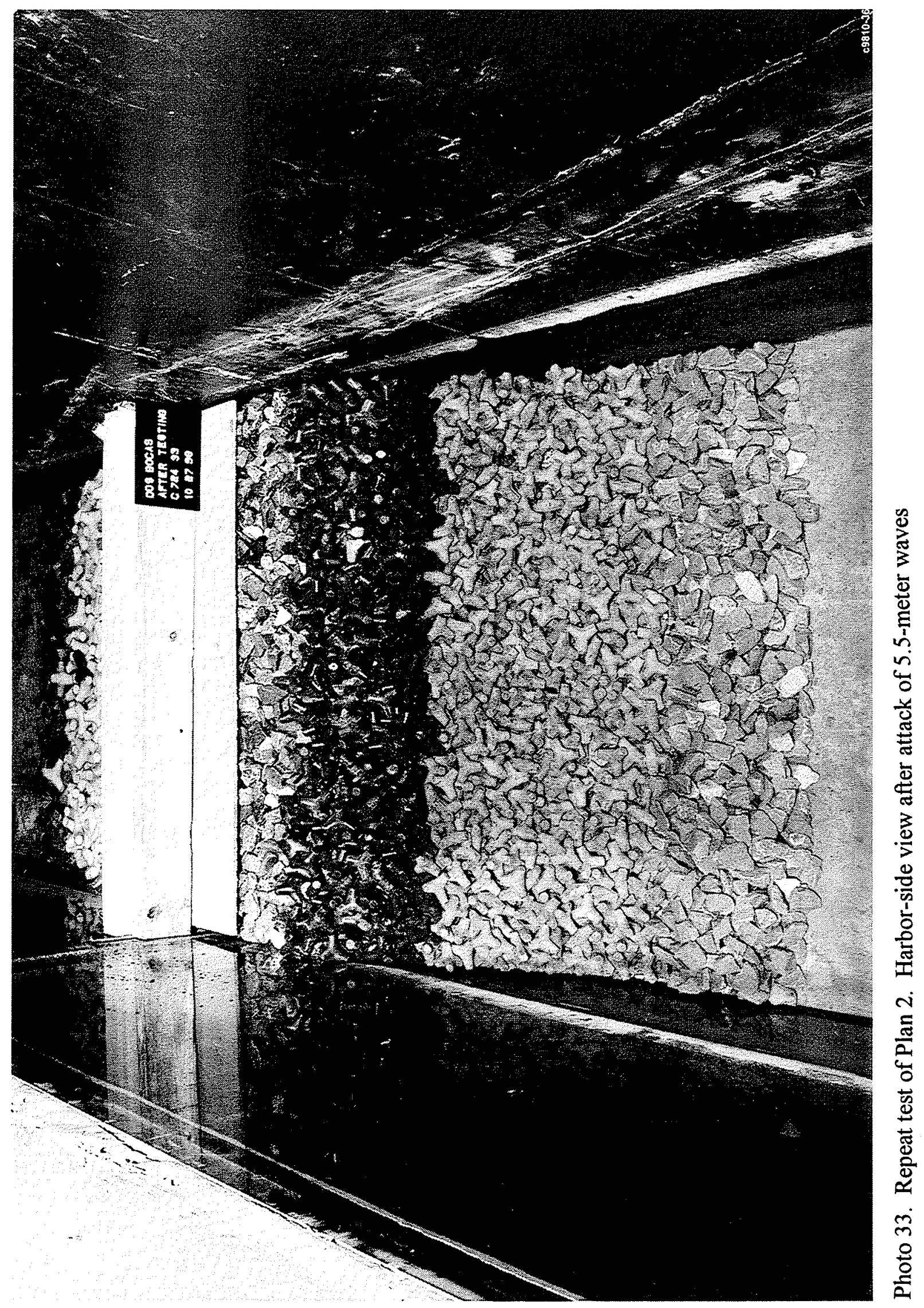



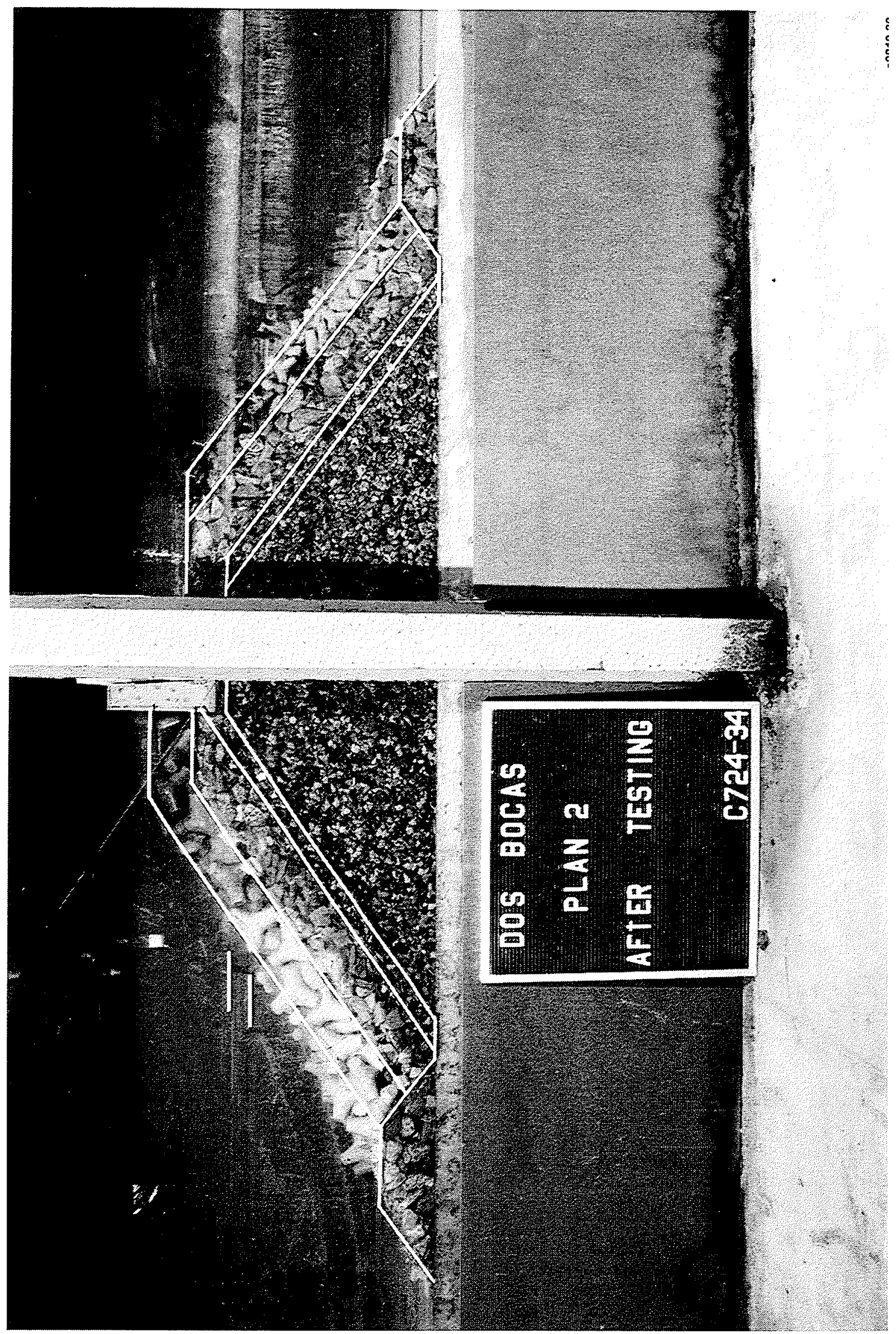

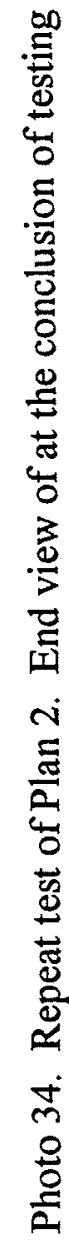




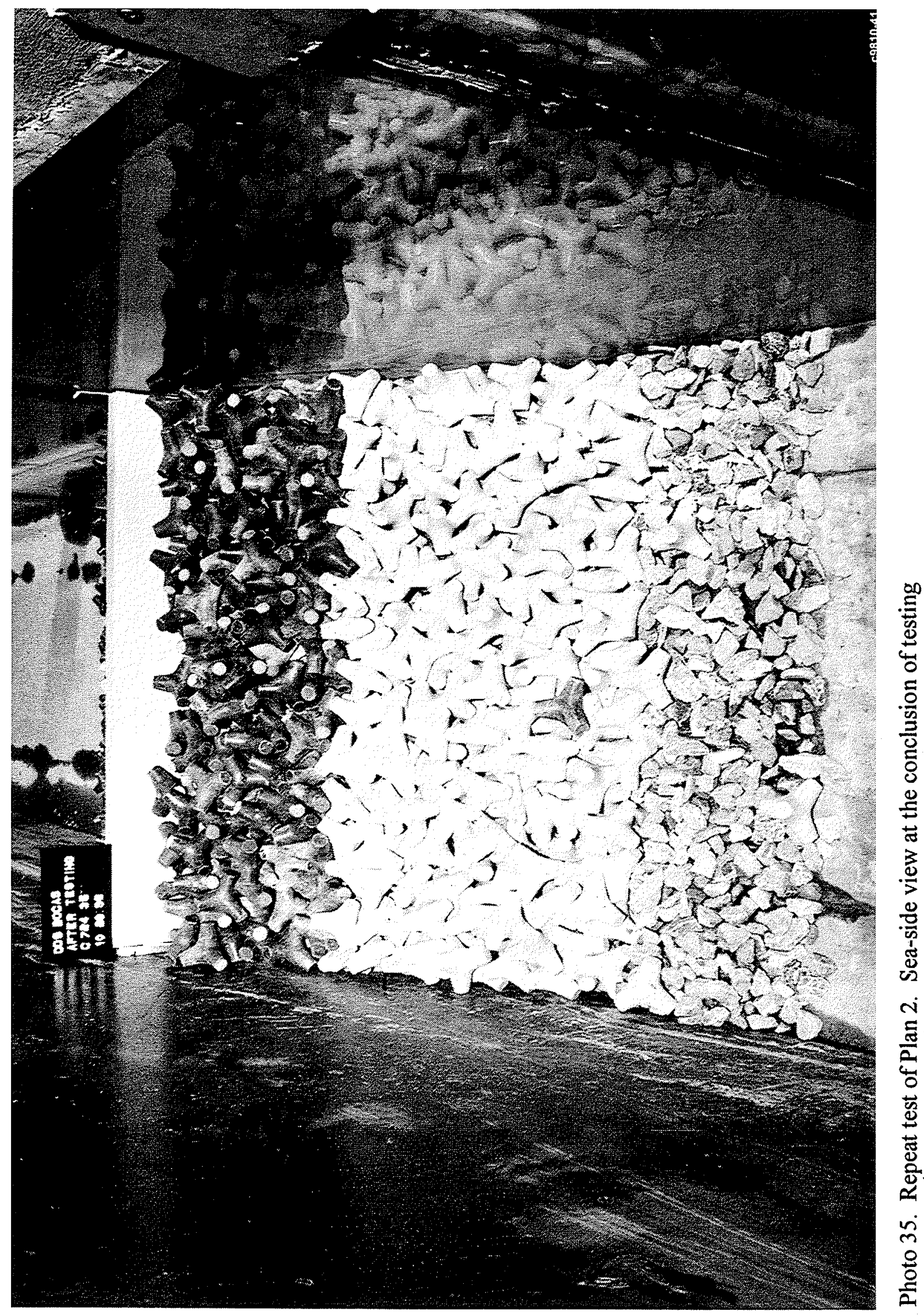




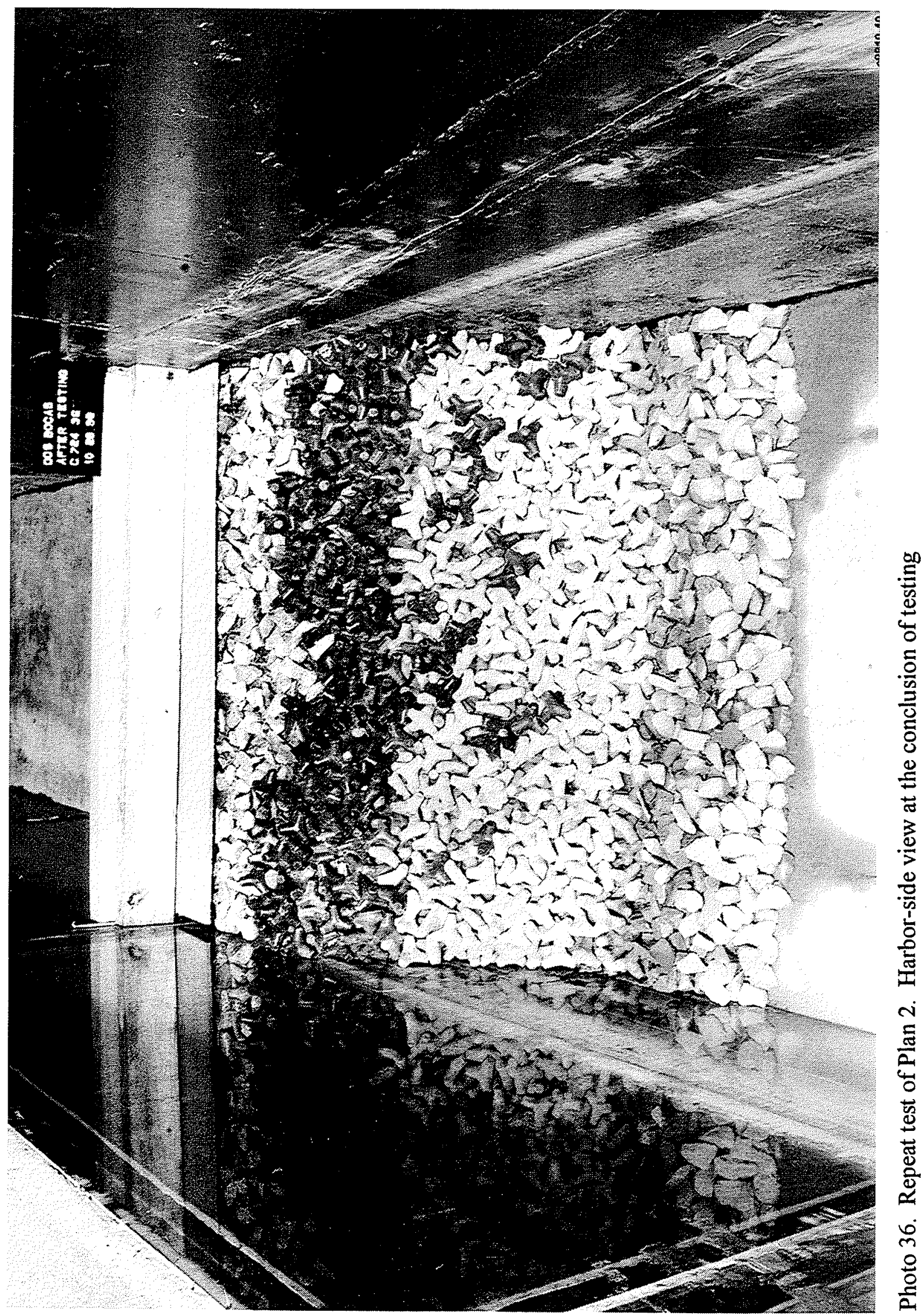




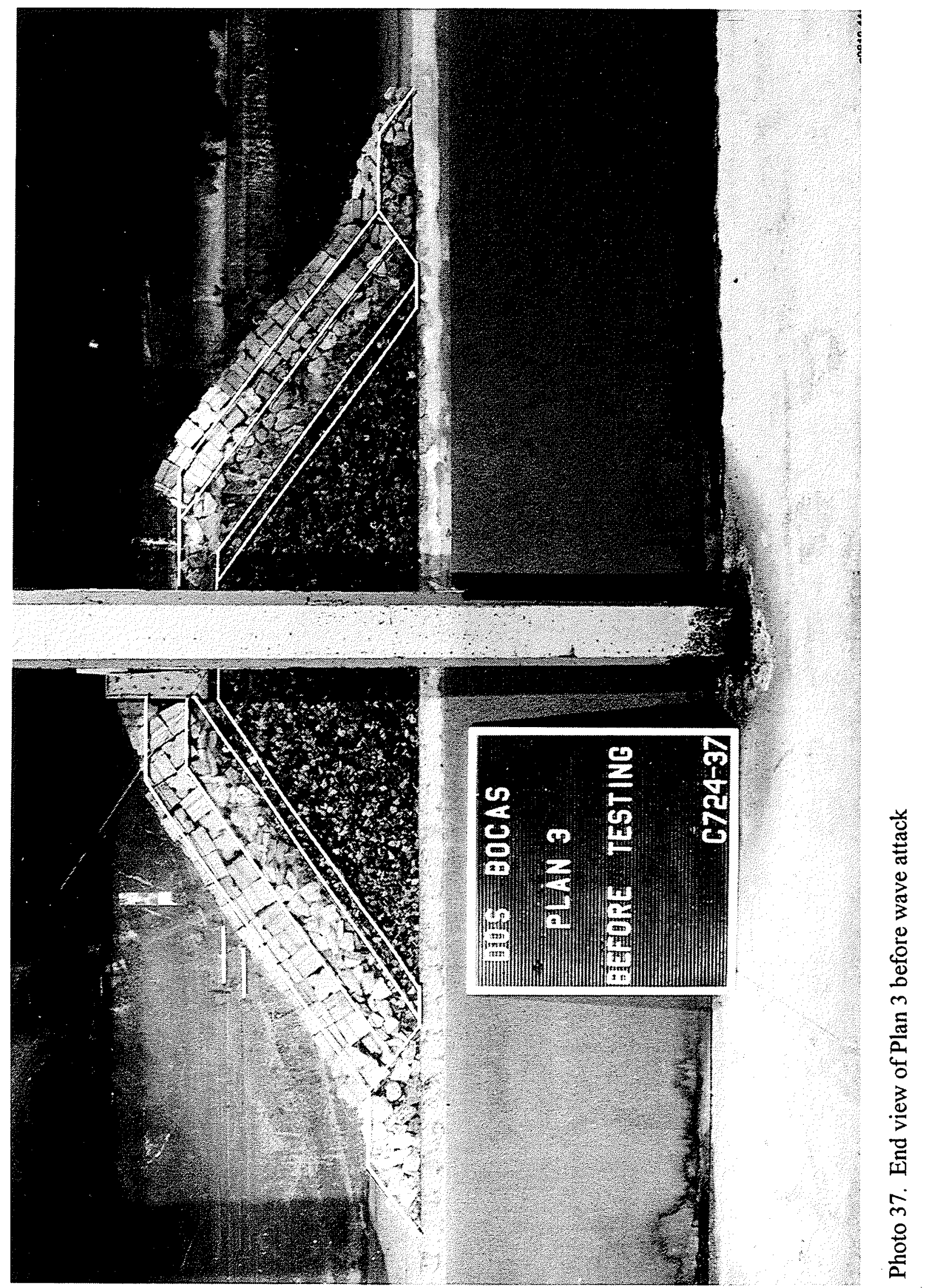




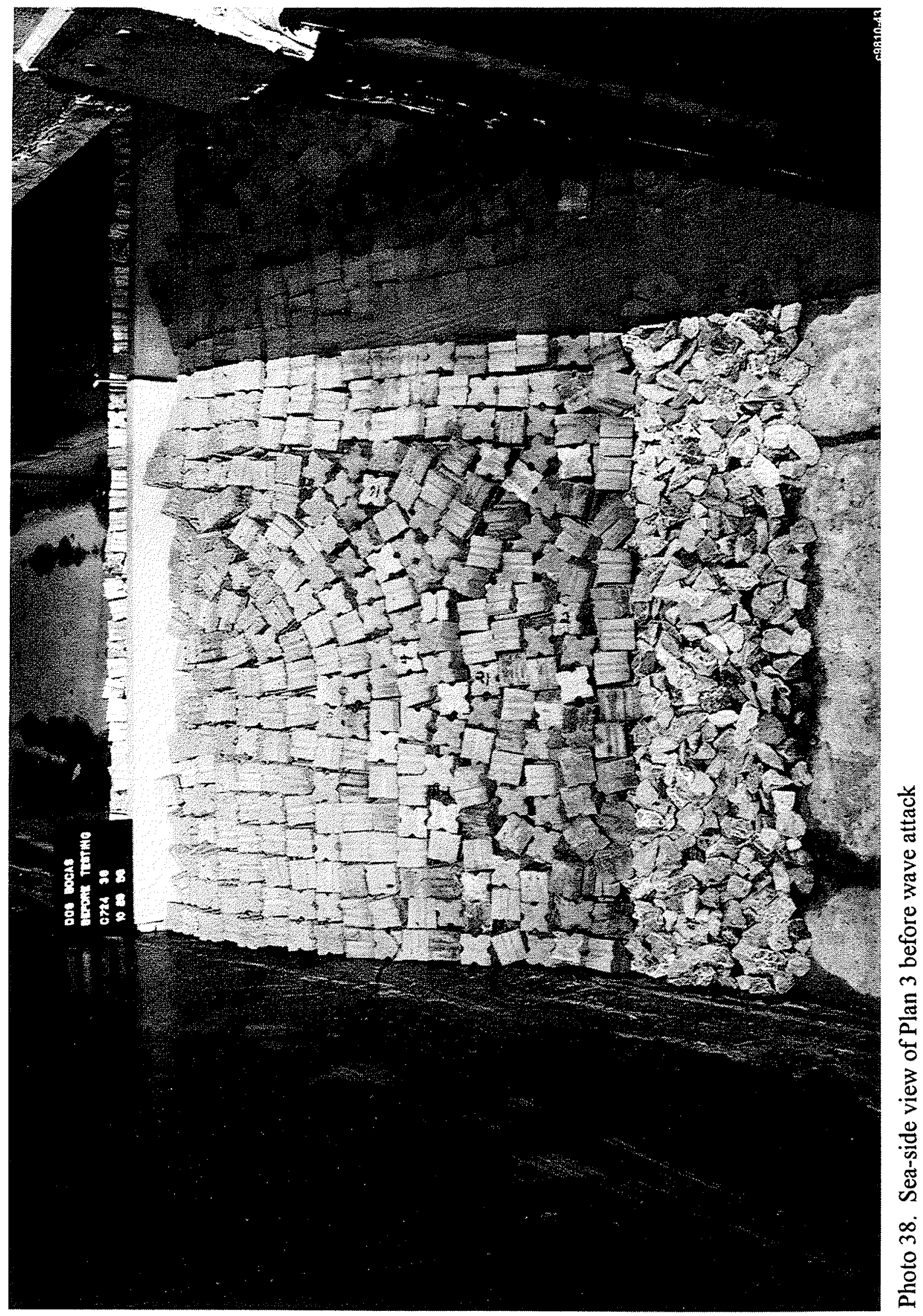




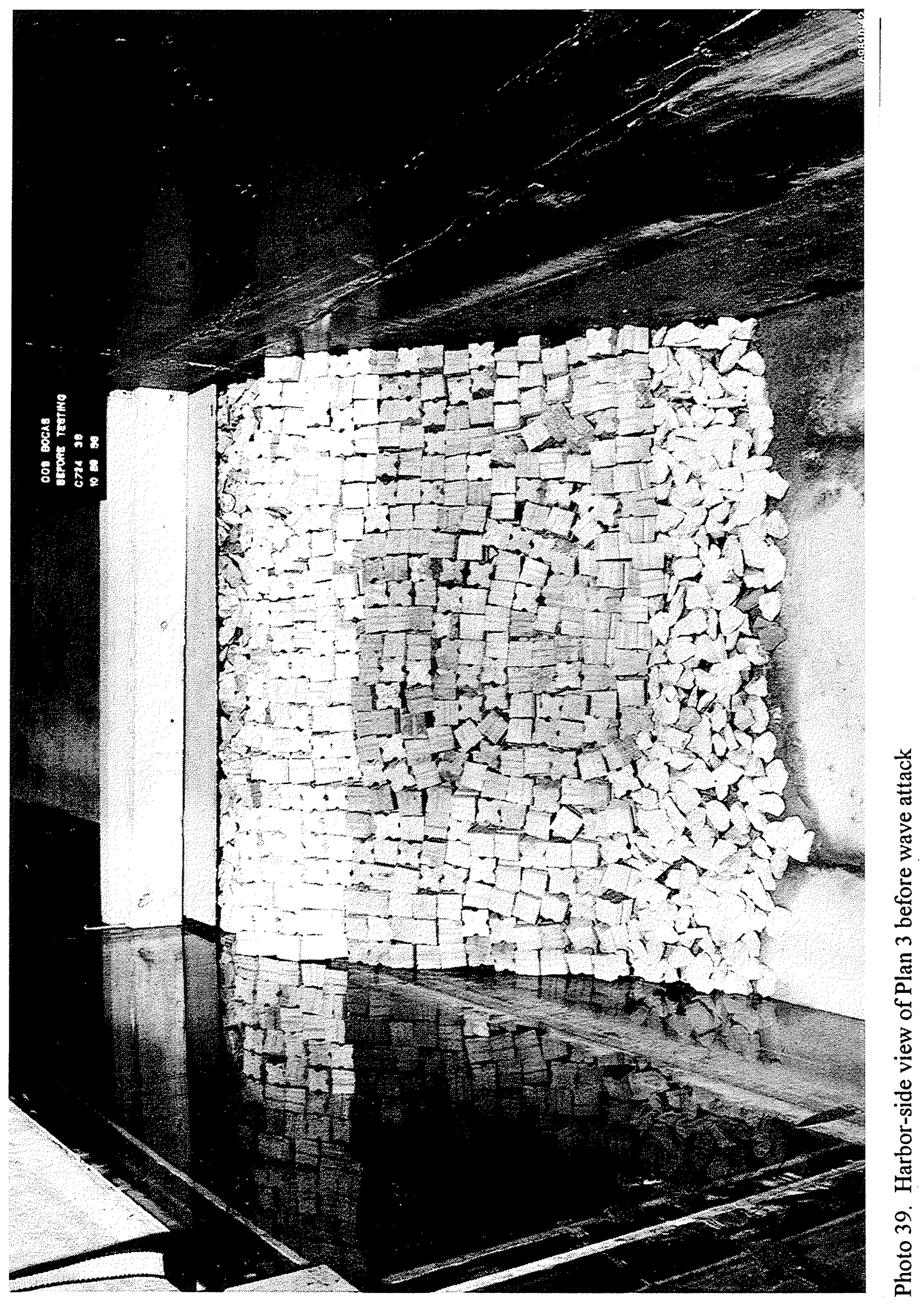



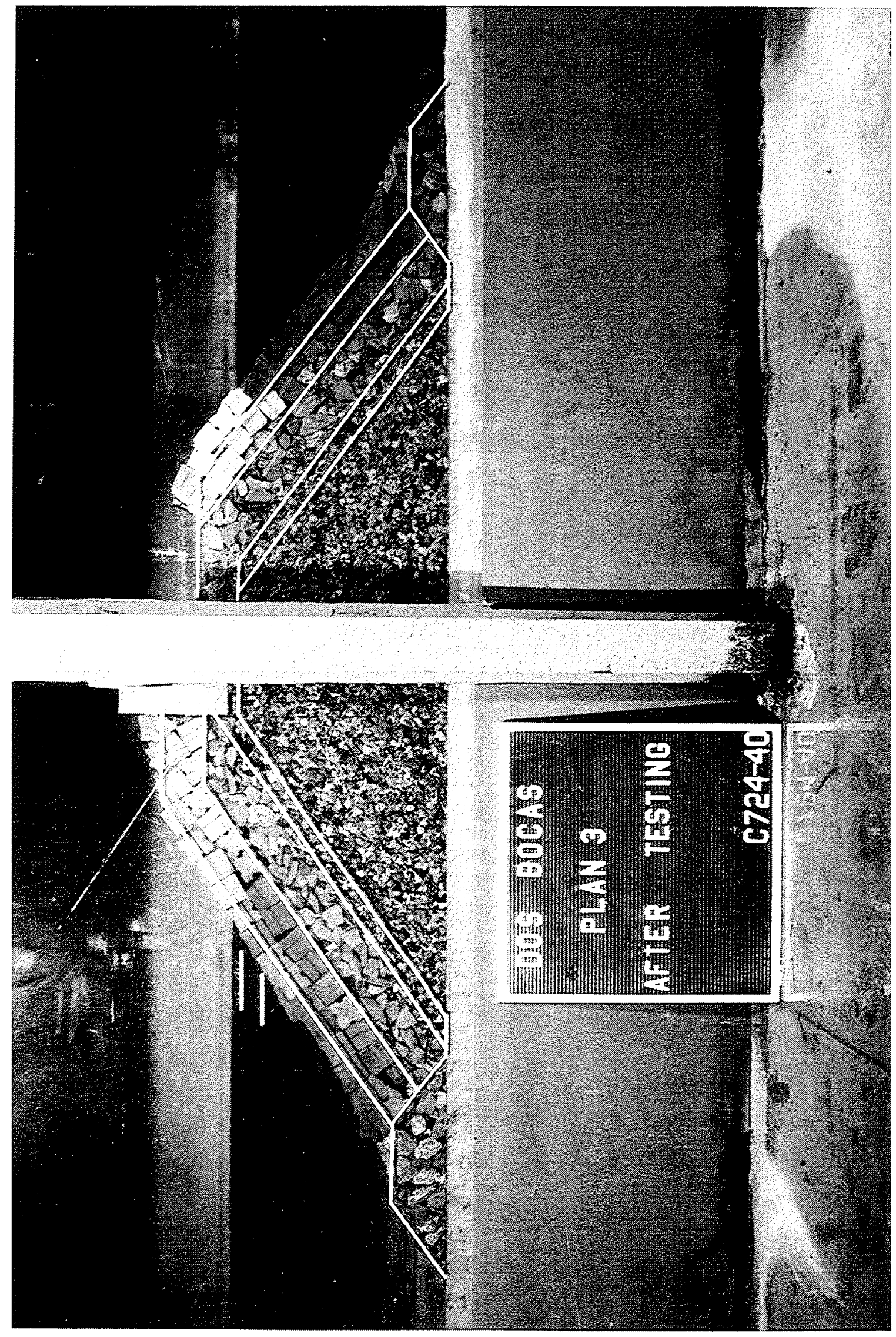

$17-2,2,1,0$

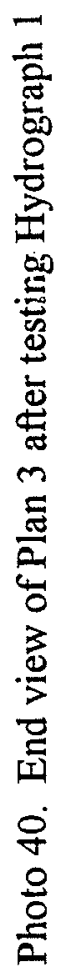




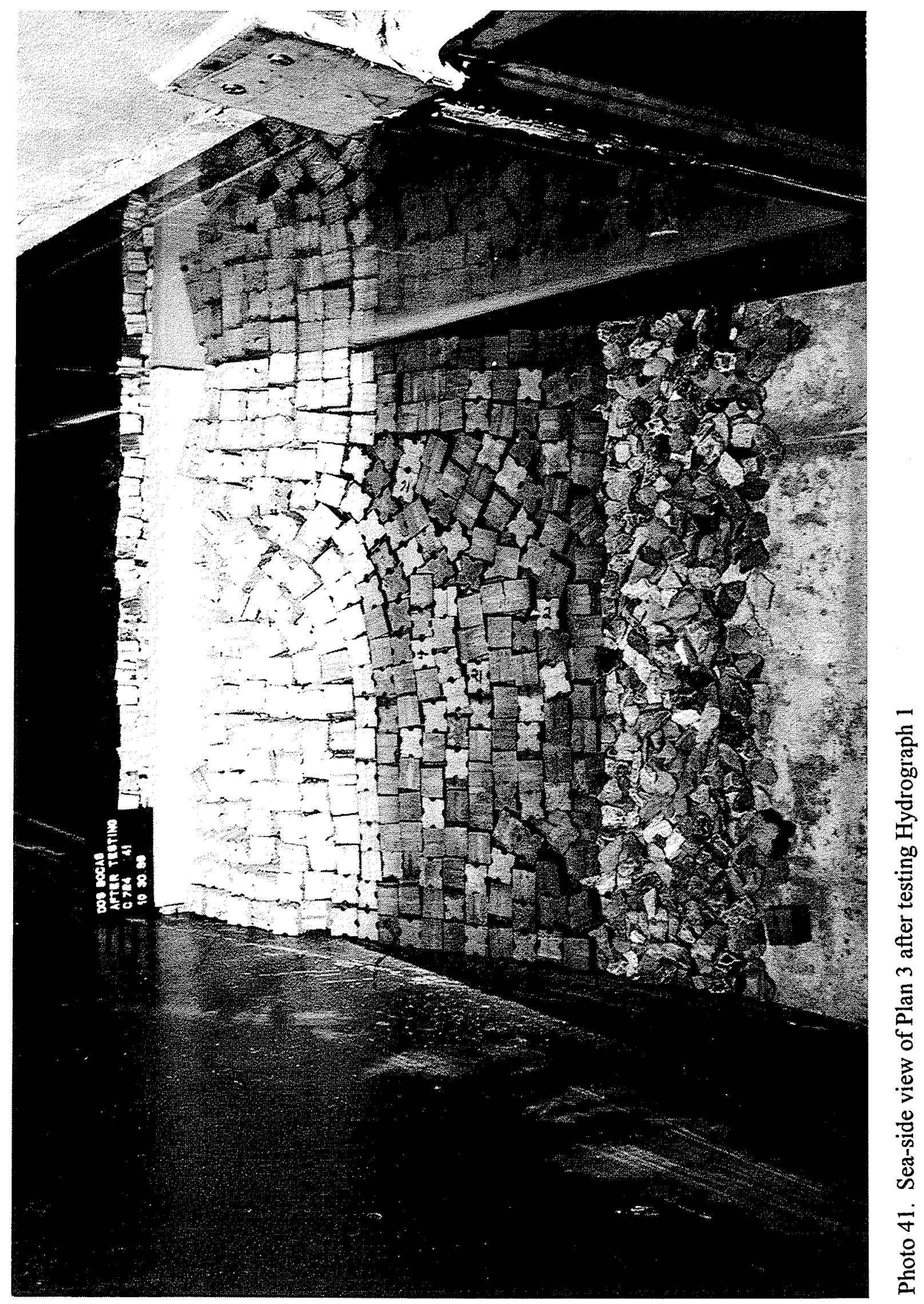




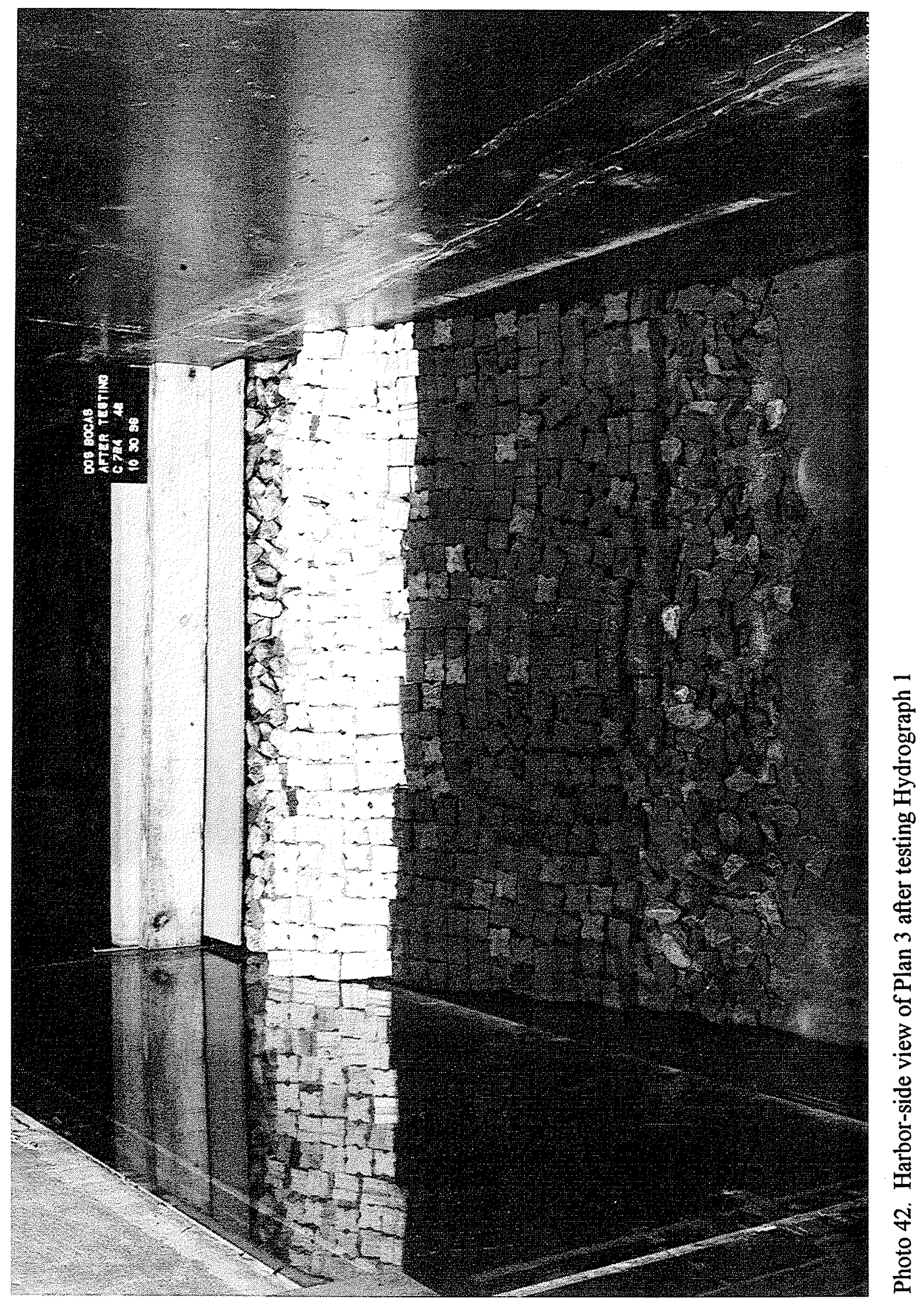



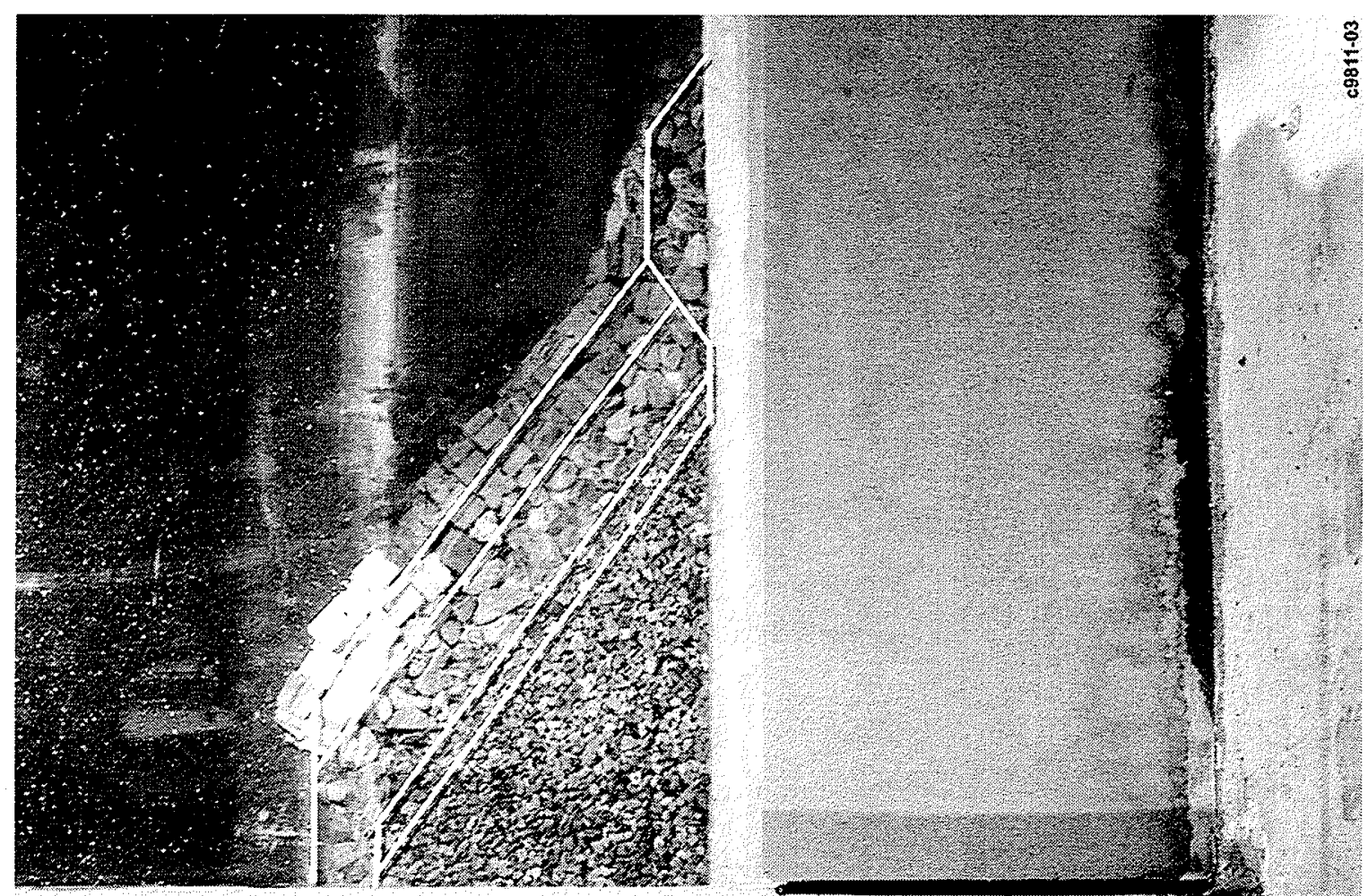


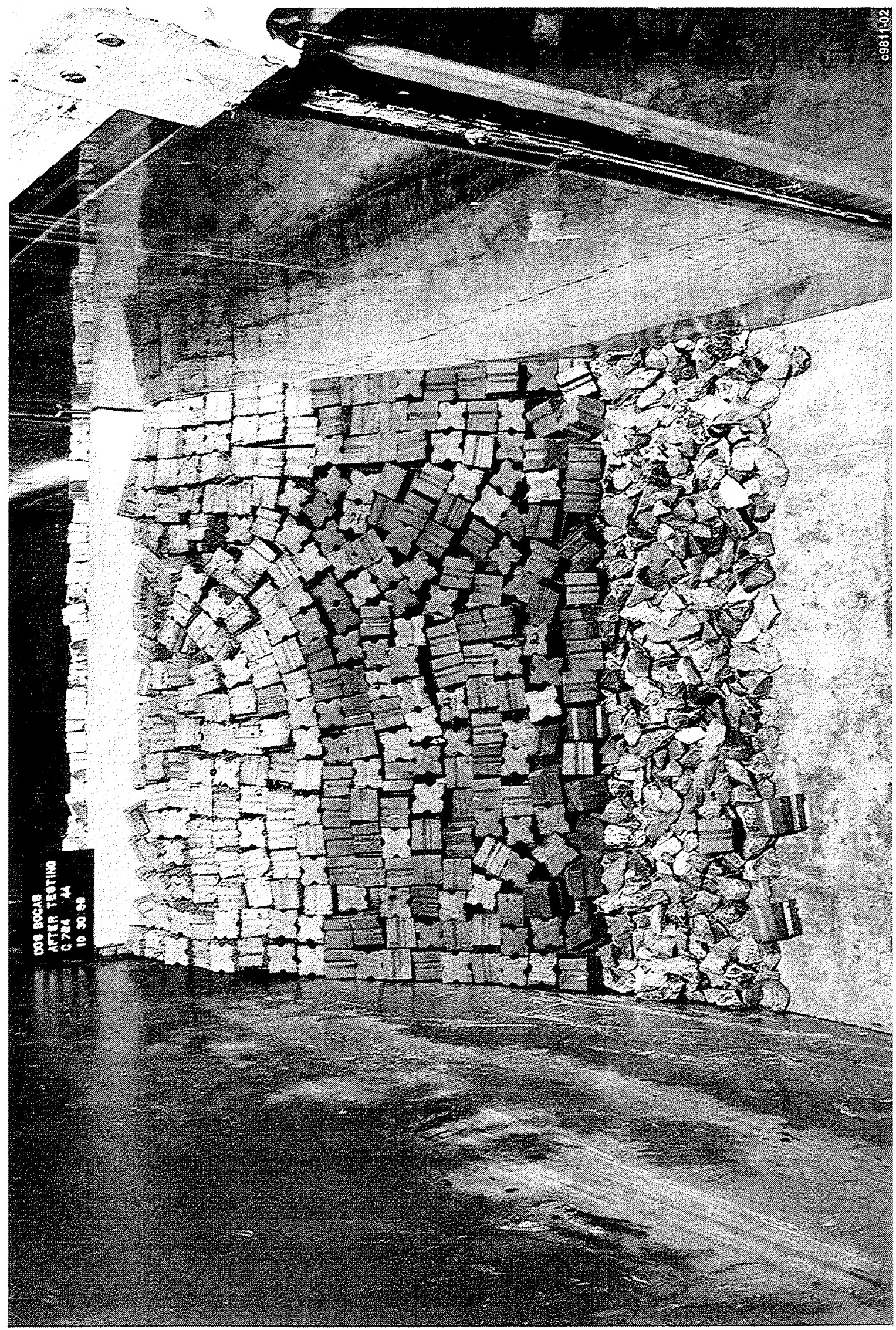

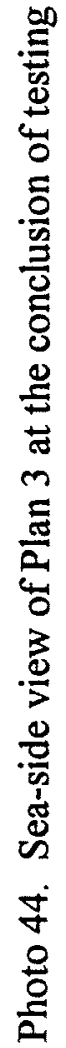




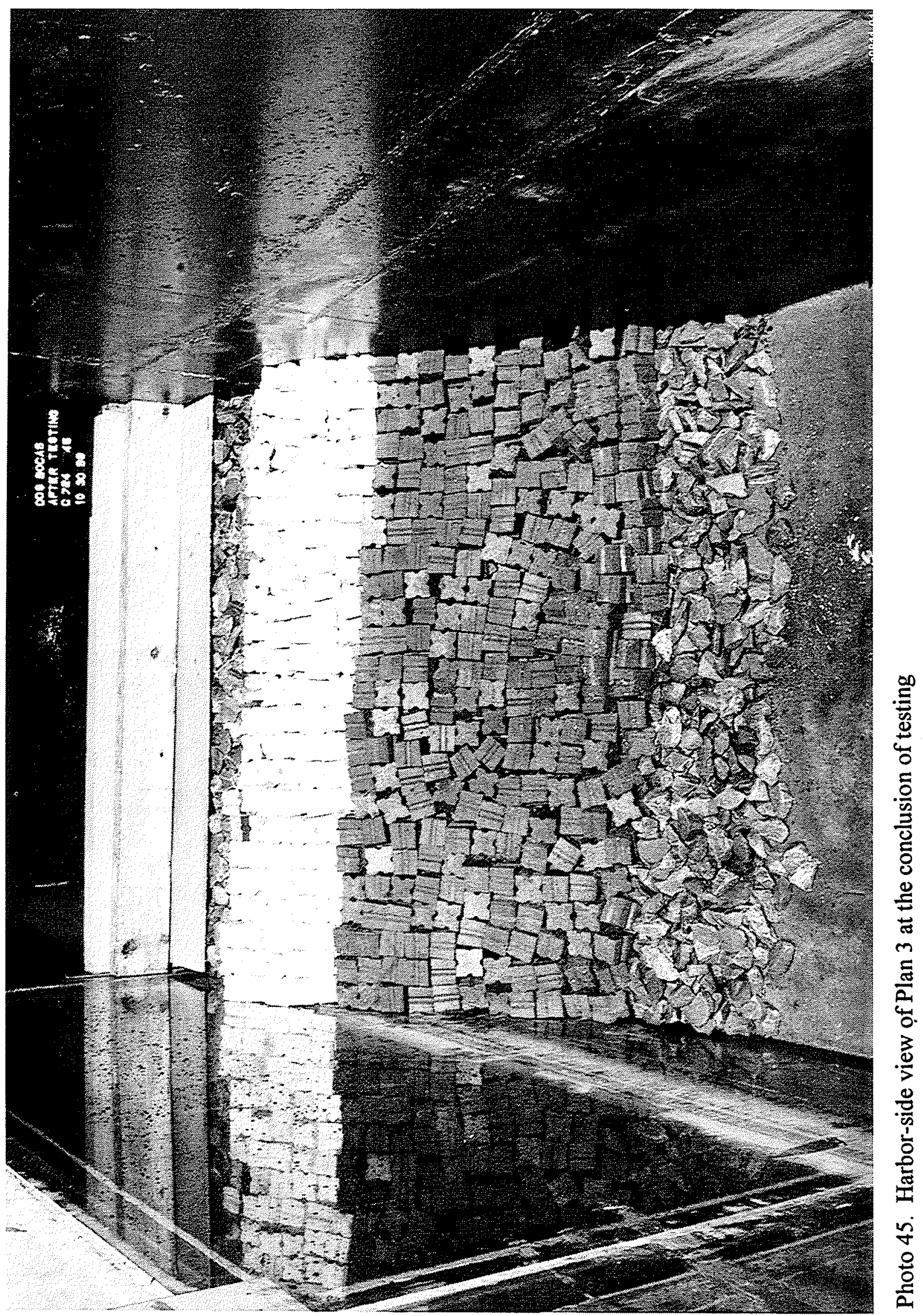



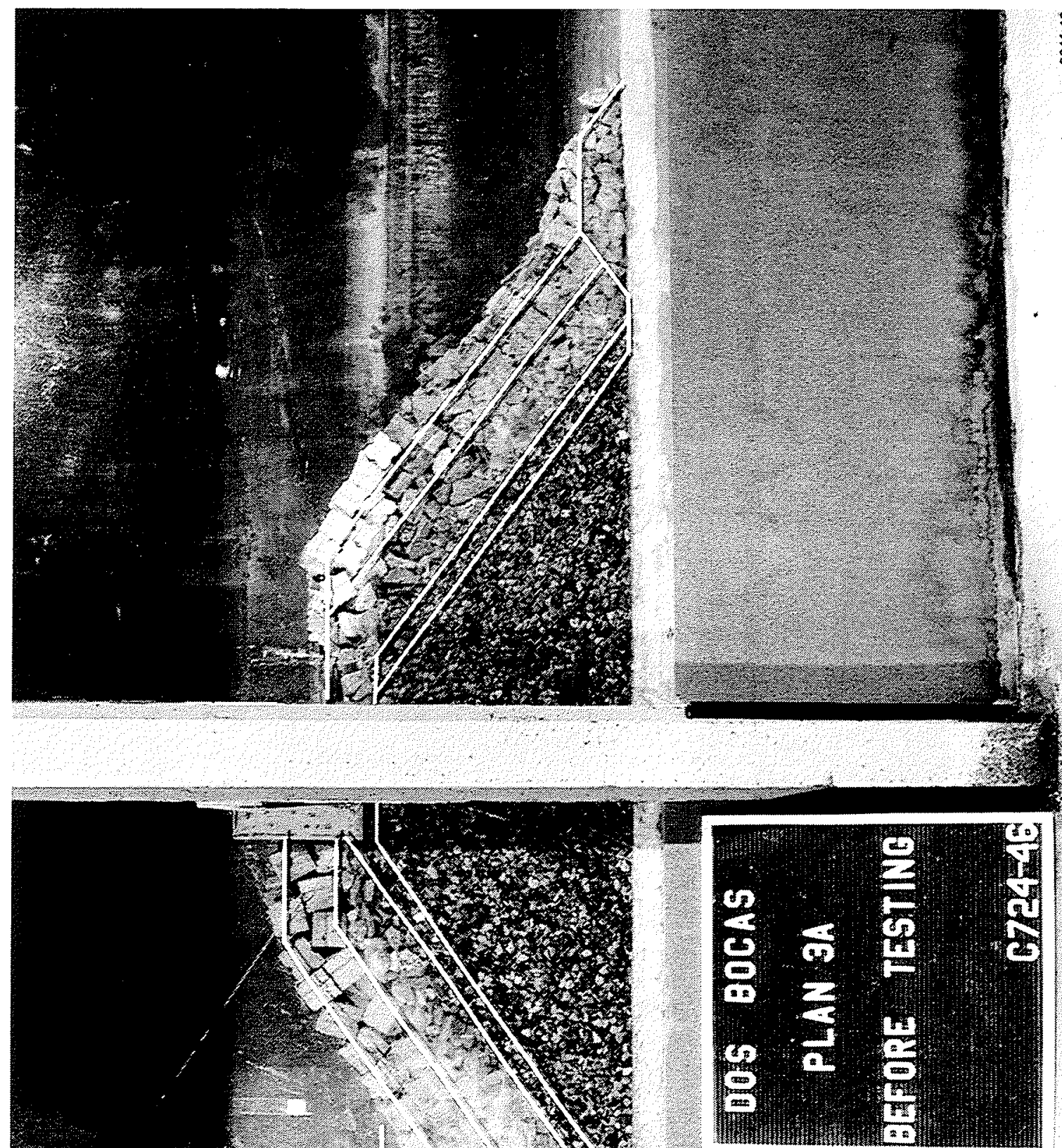

옿

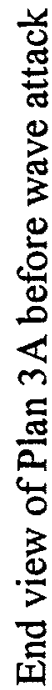

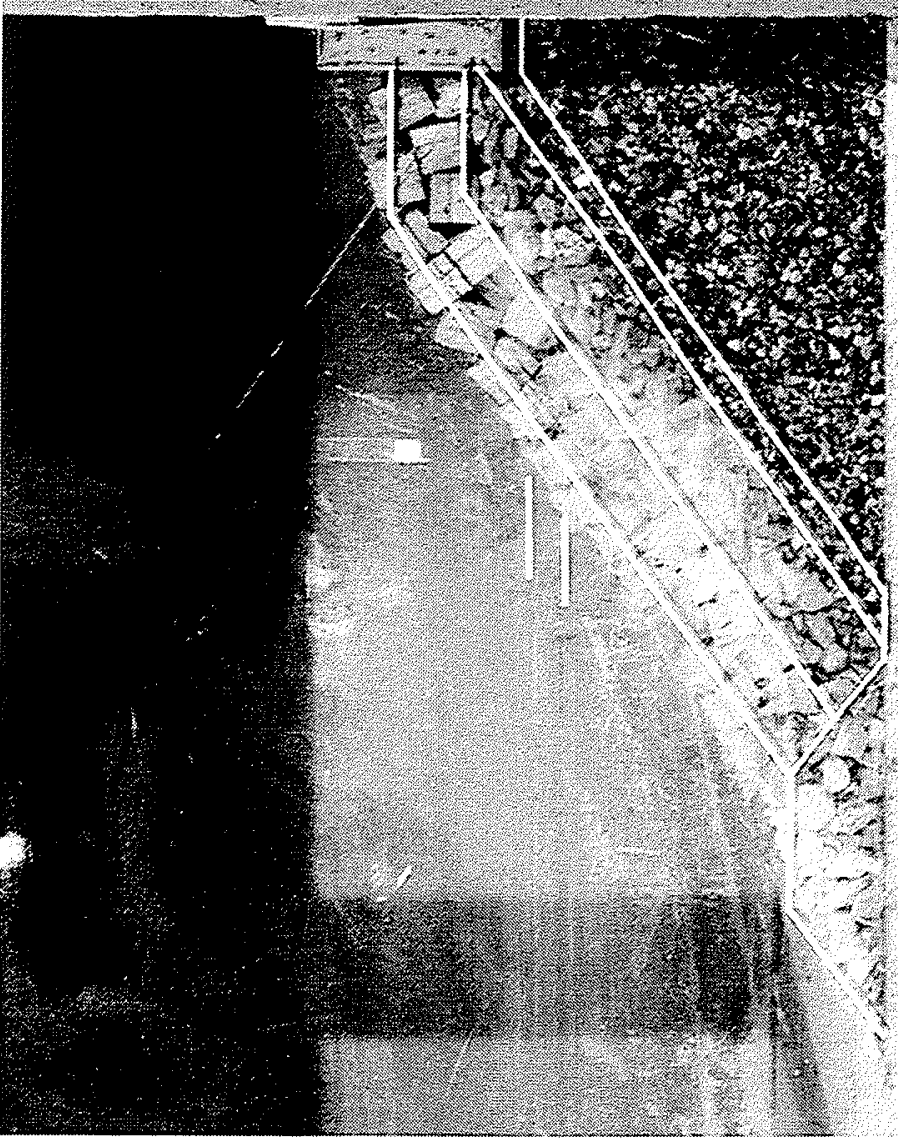

q

융 


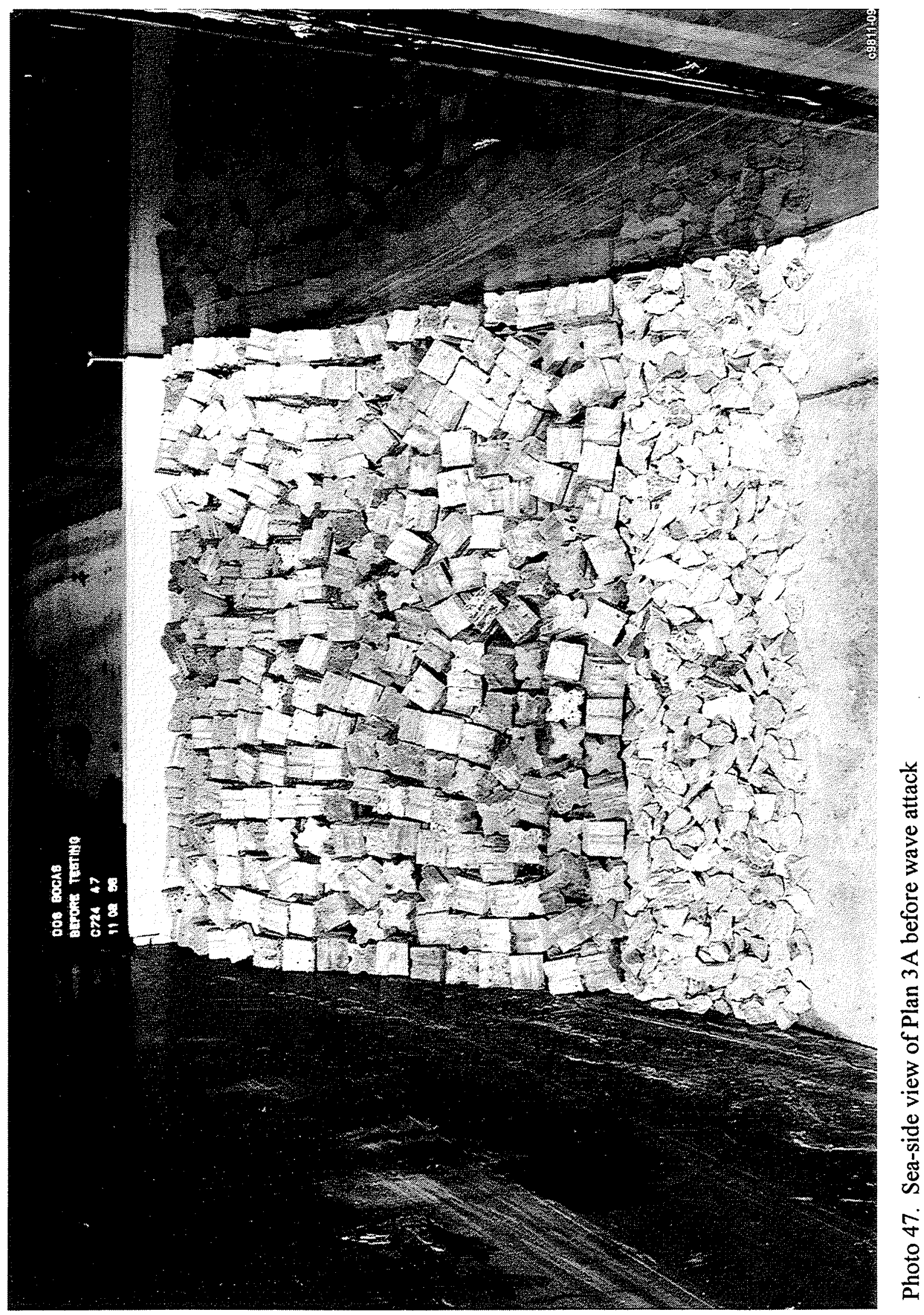




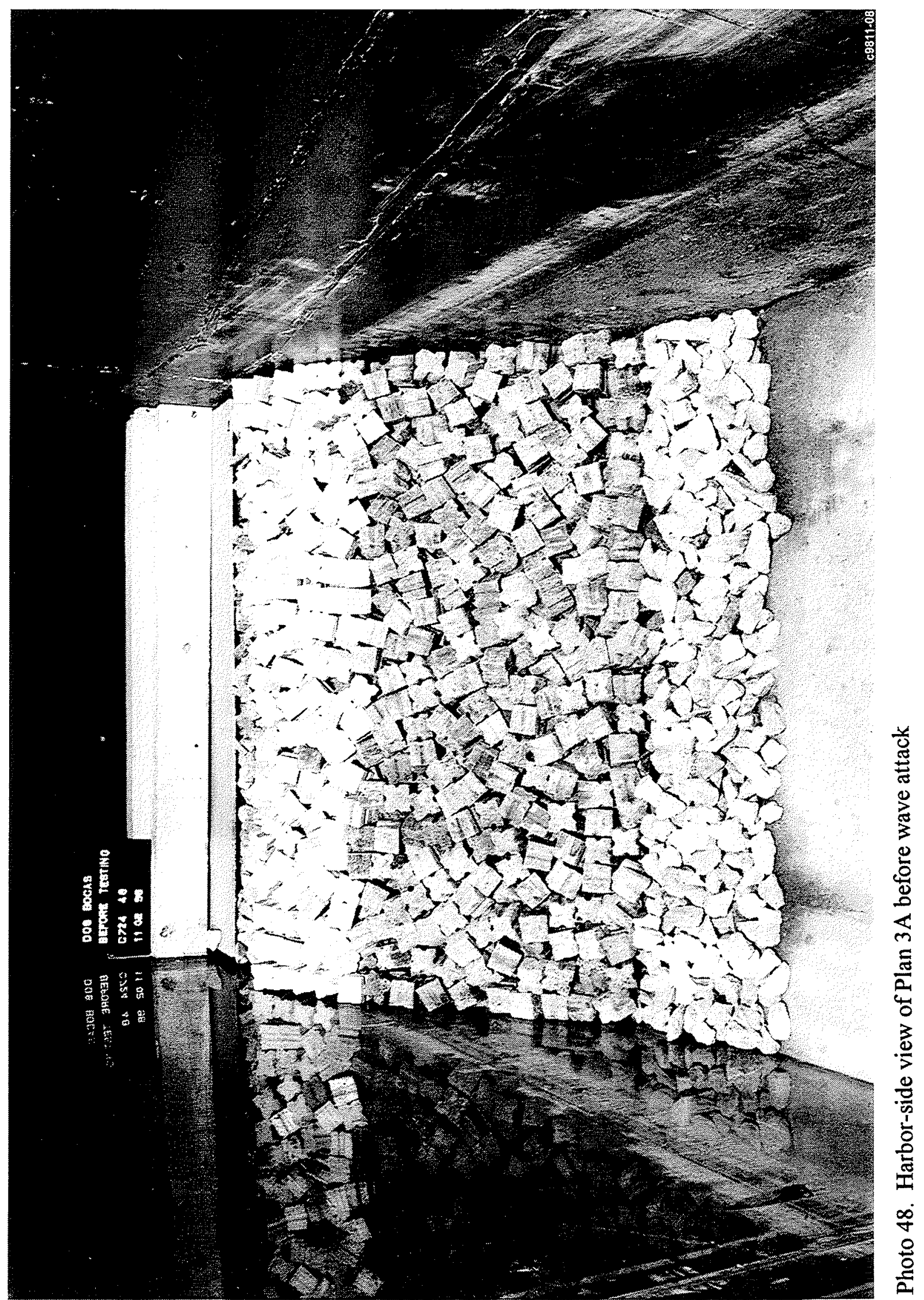



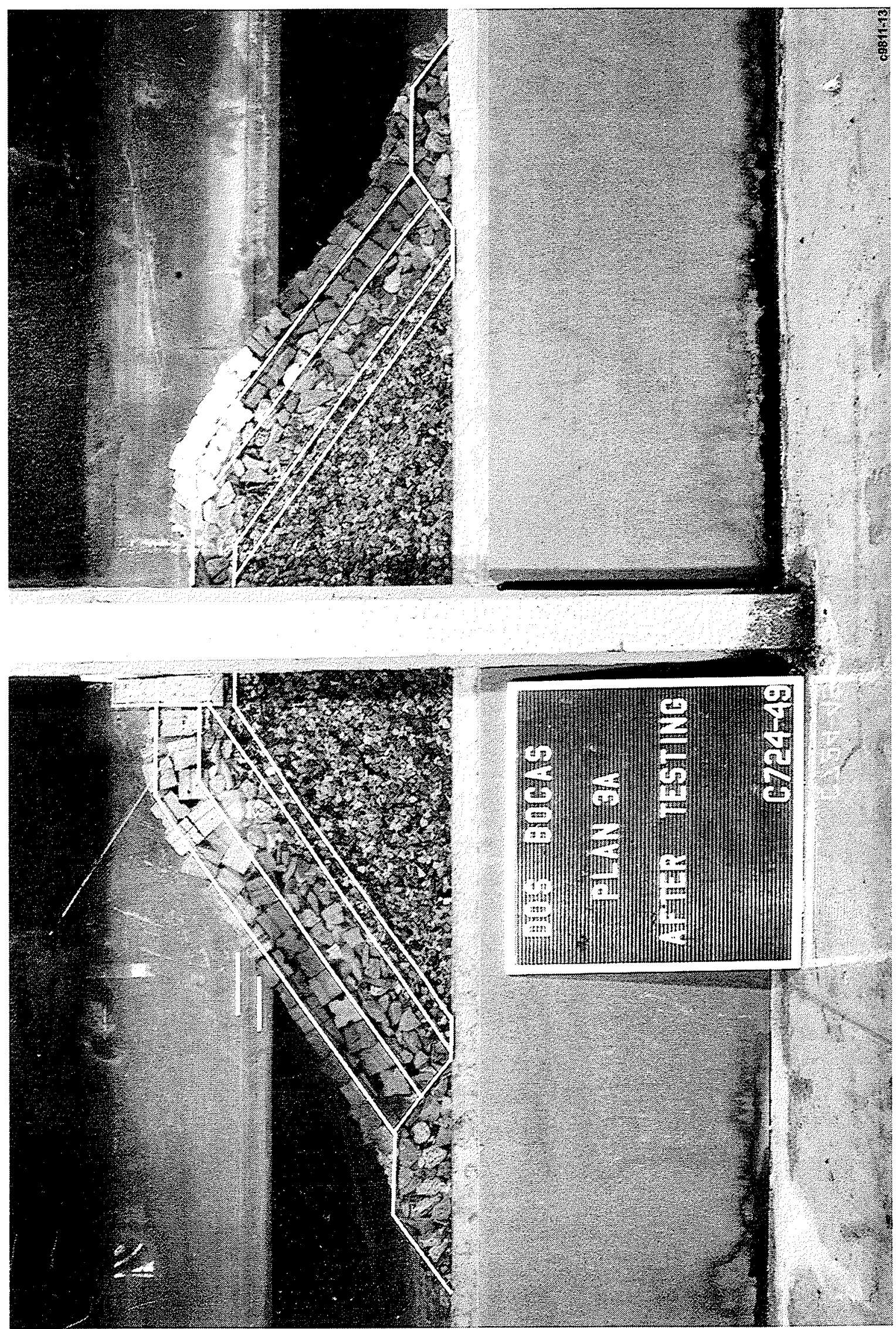

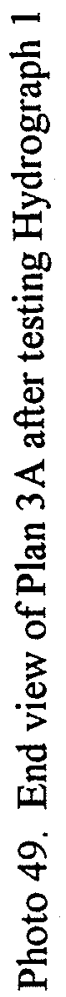




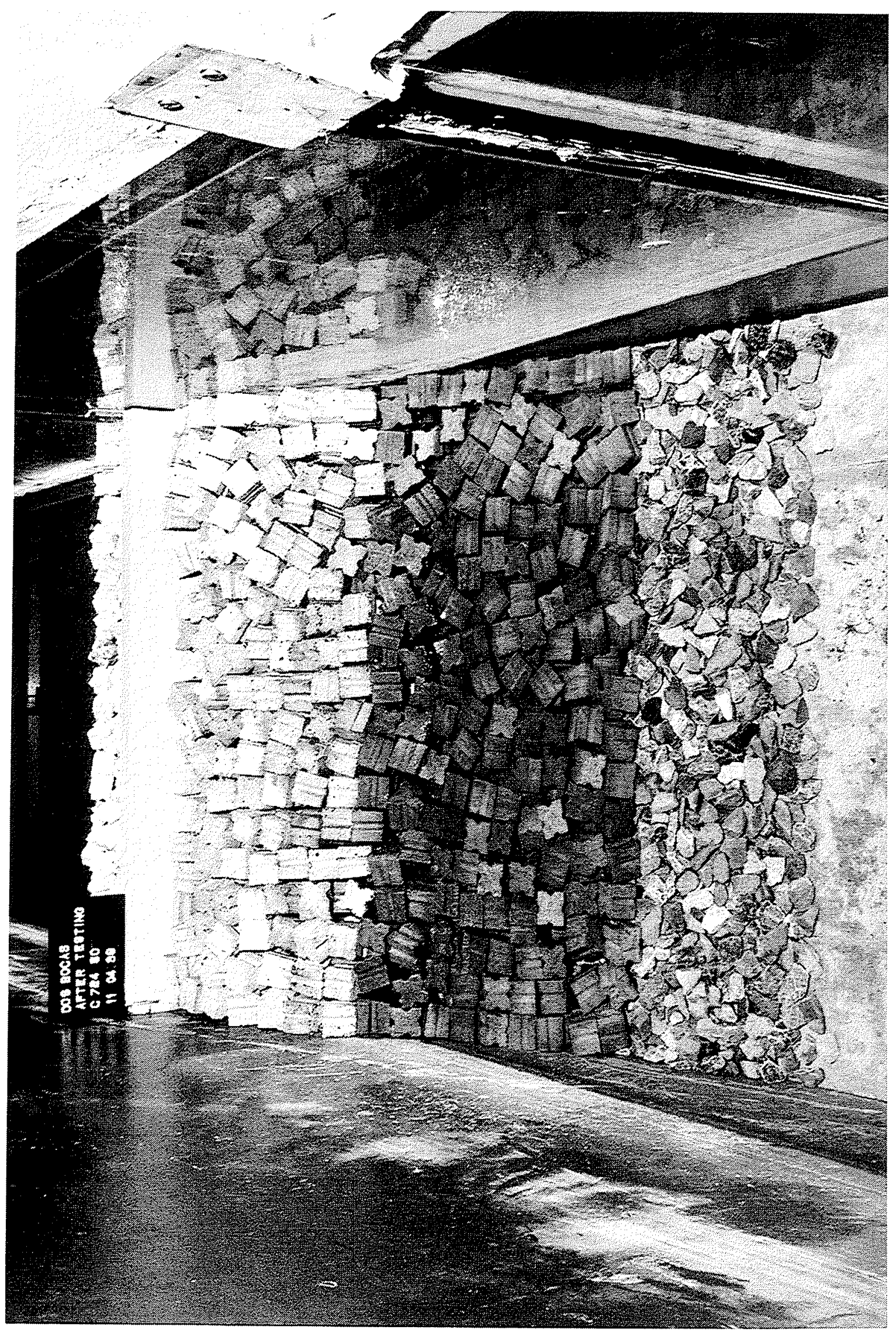

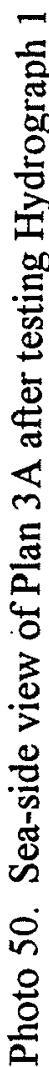




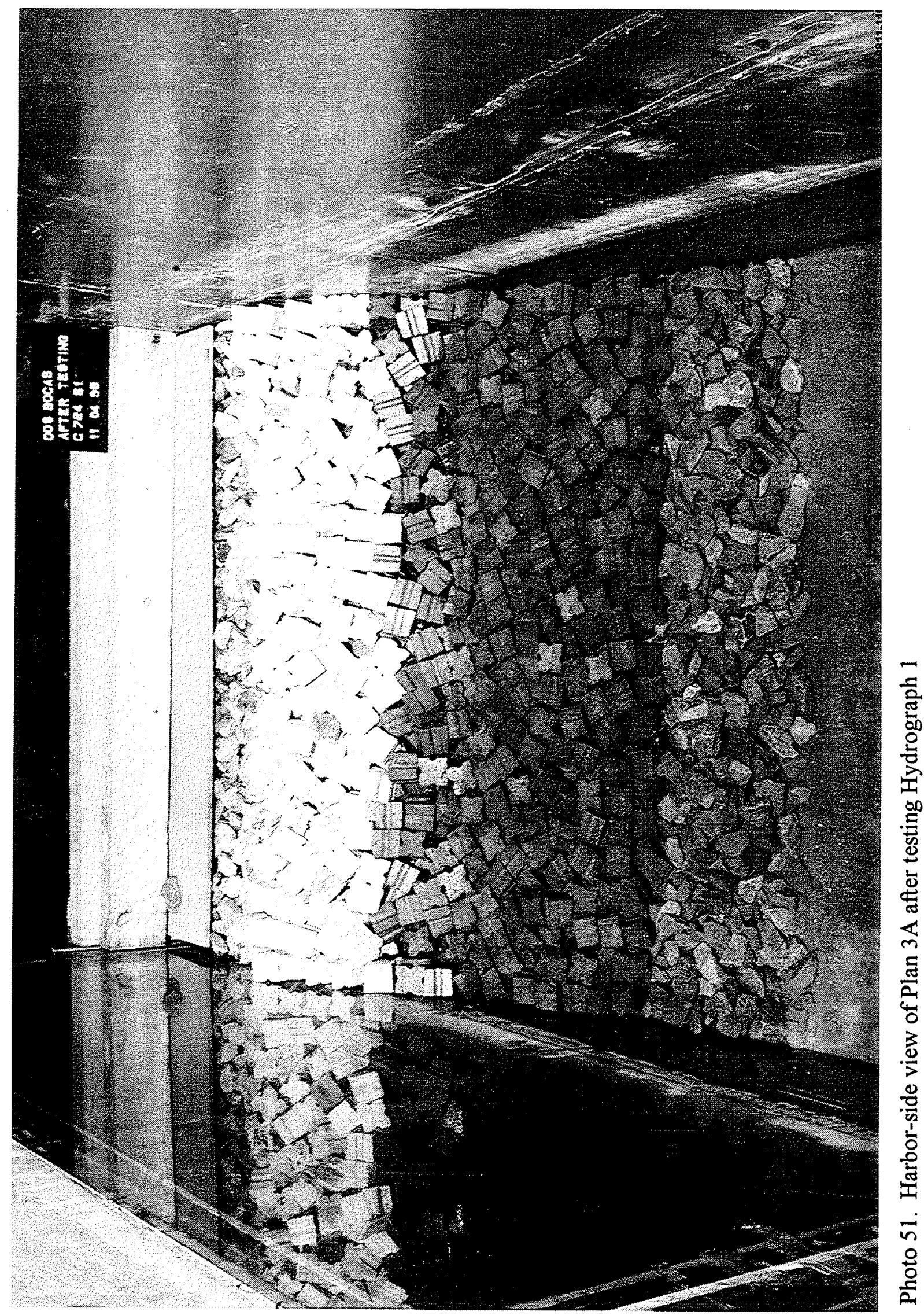



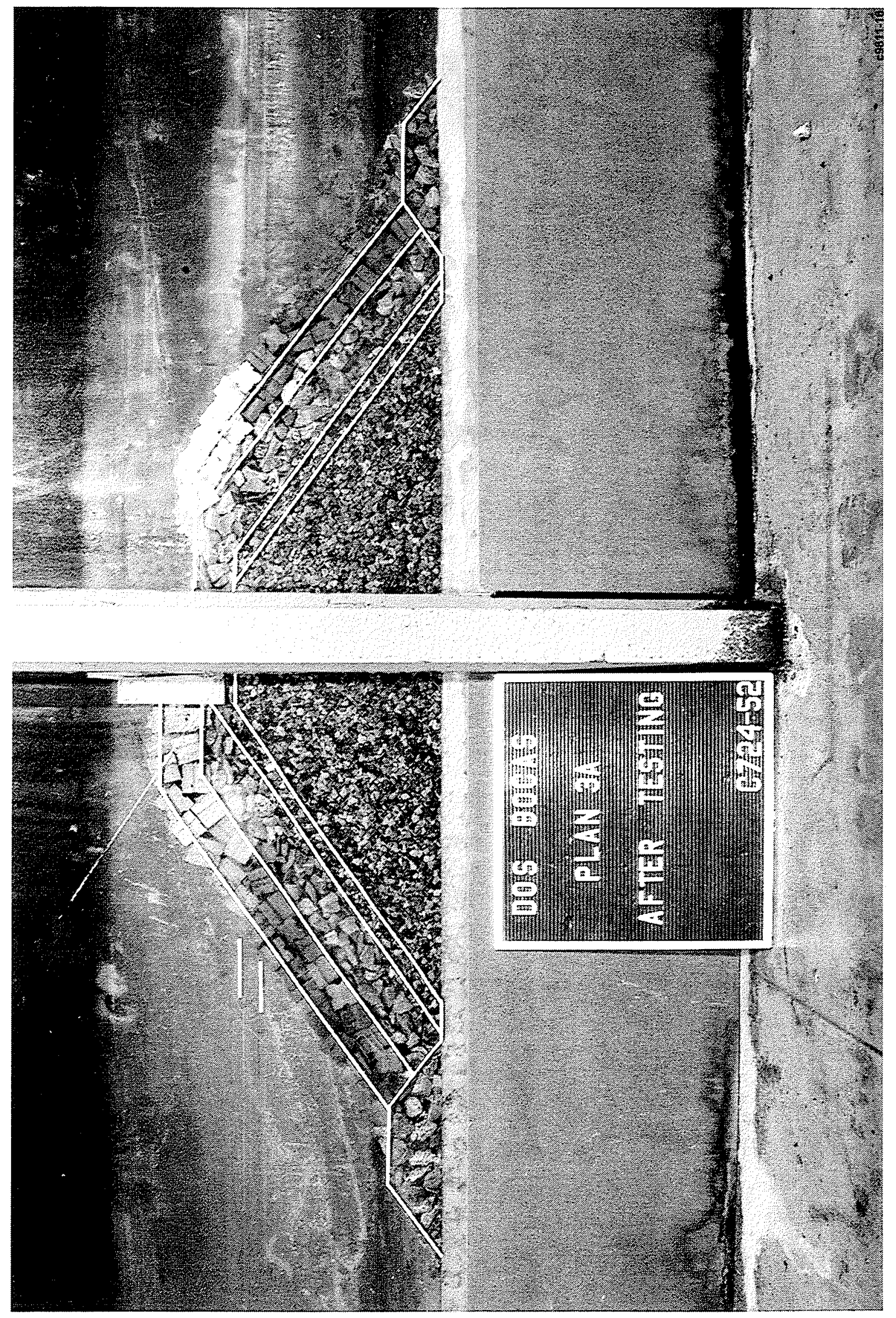

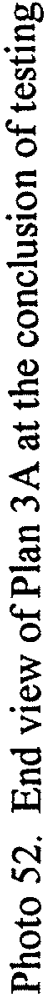




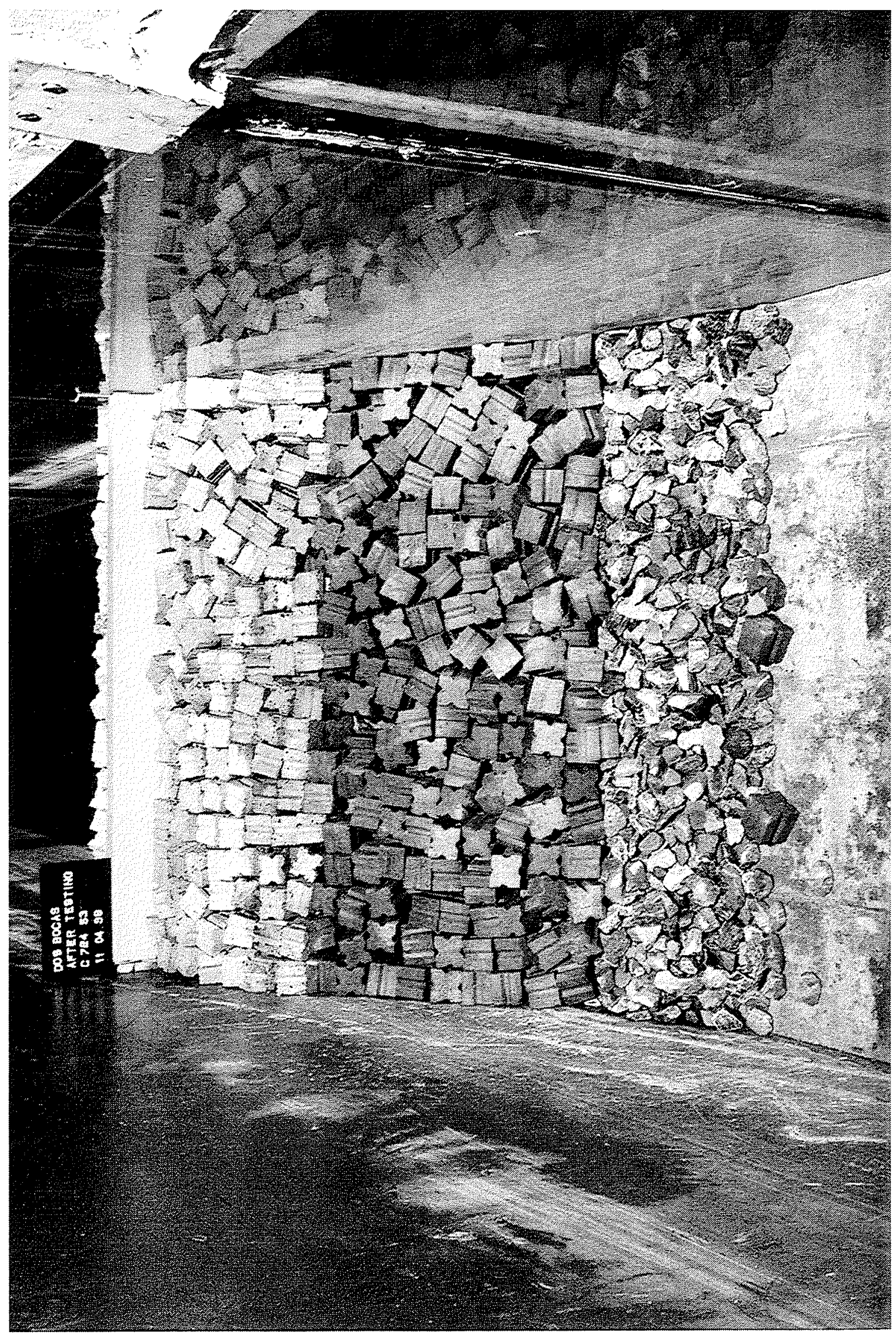

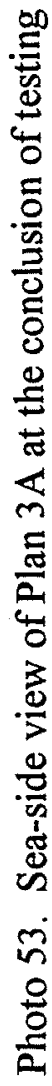




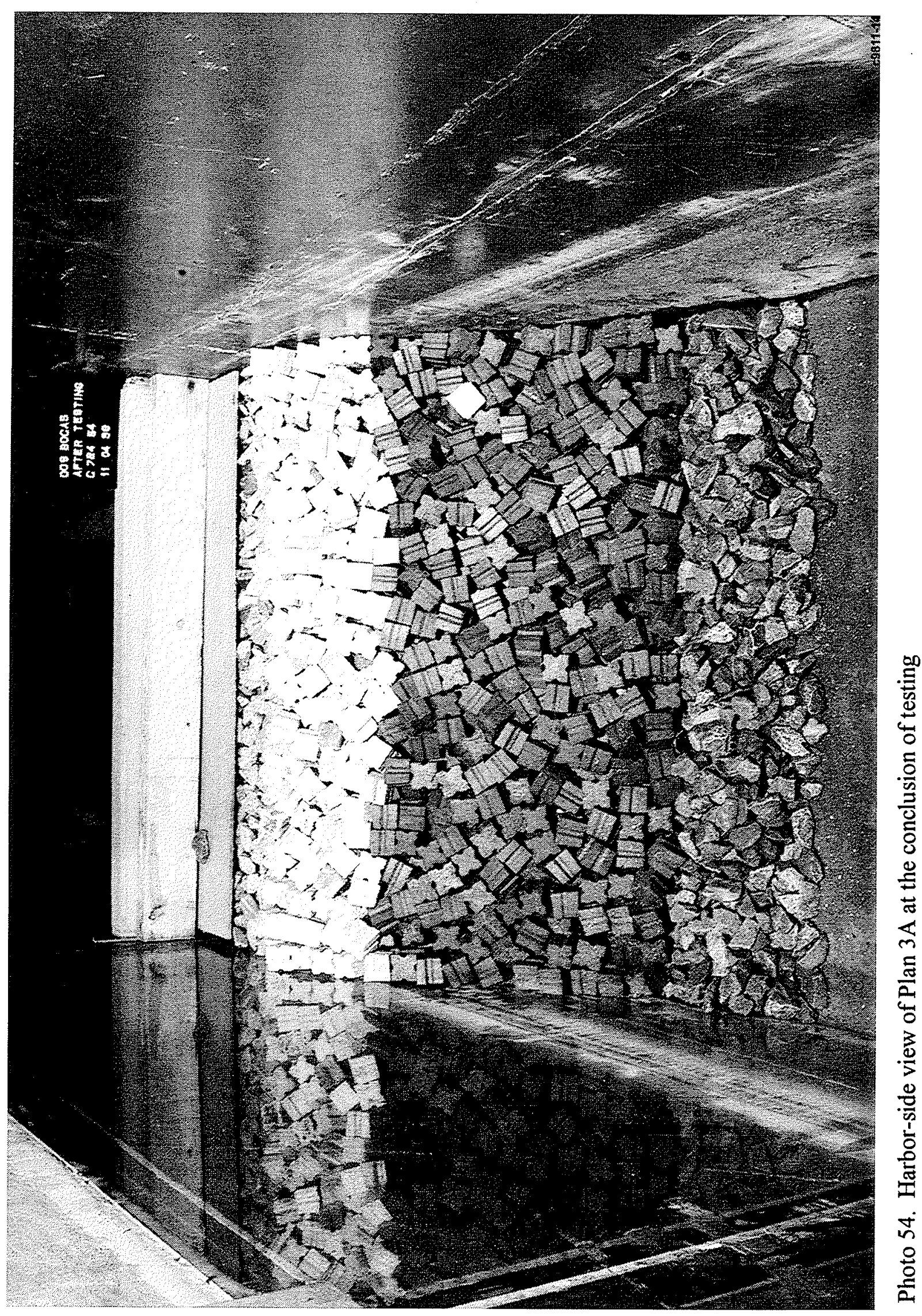



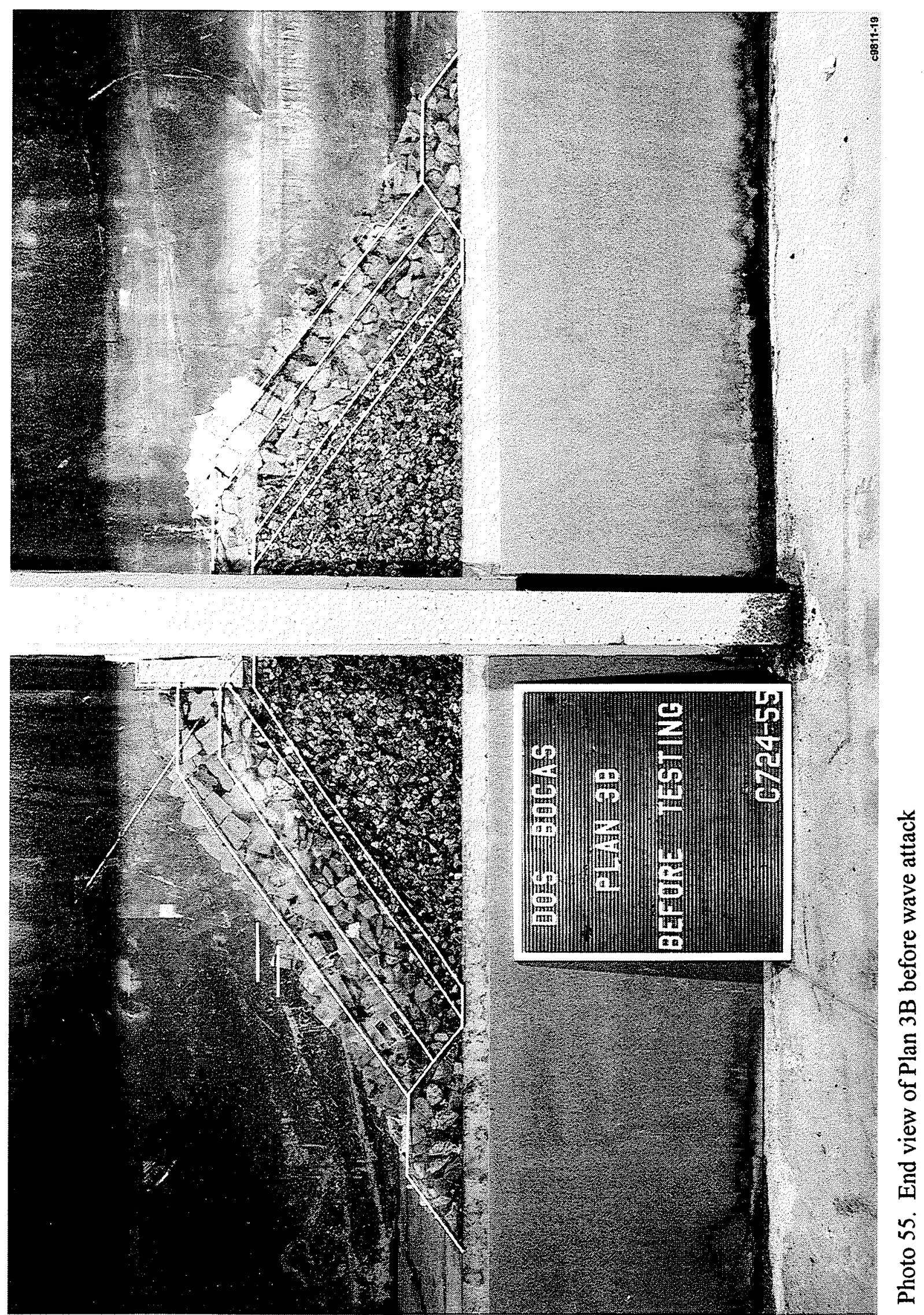


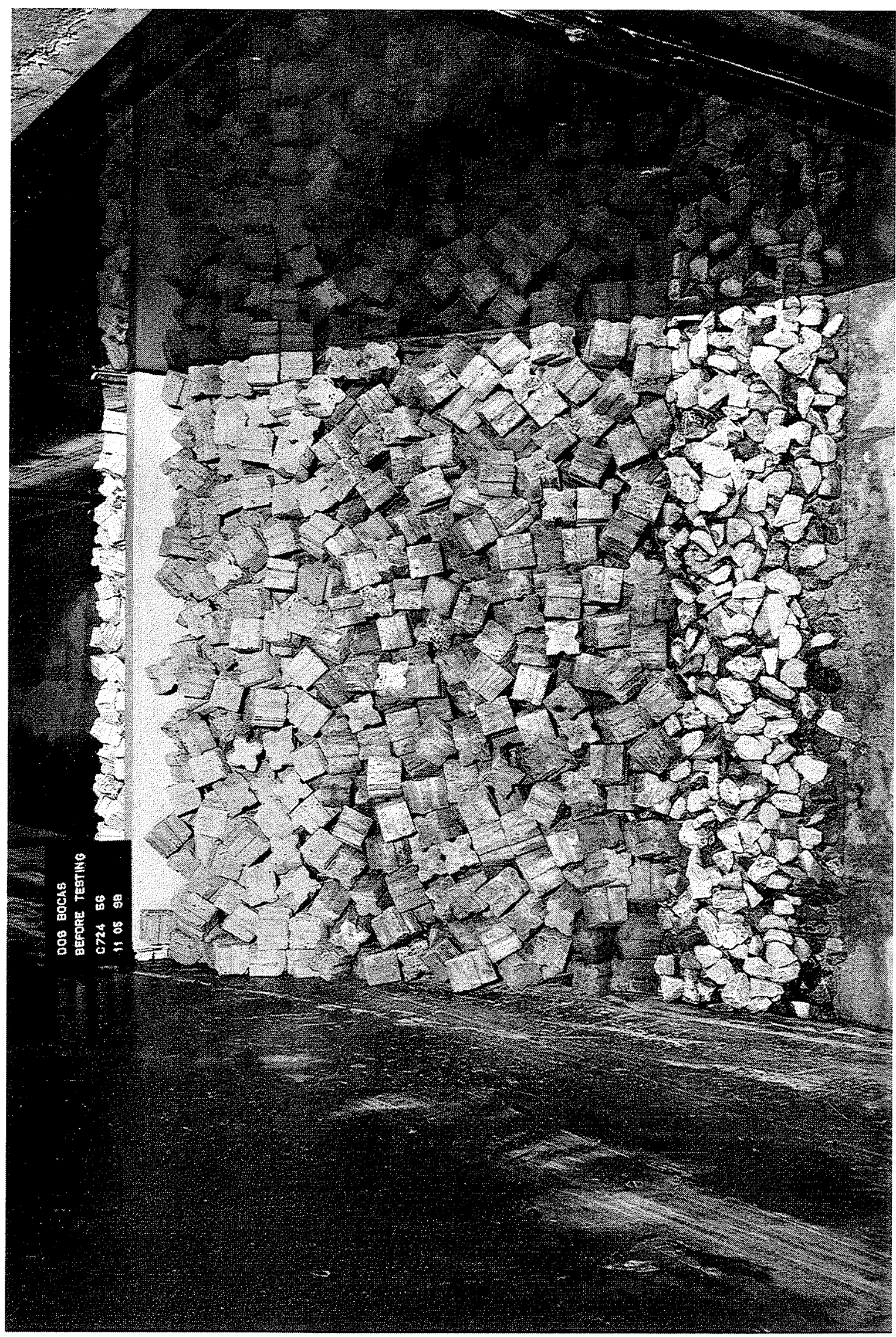

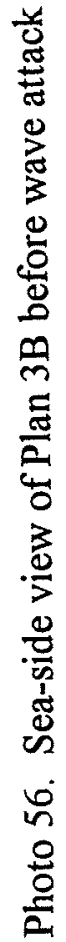




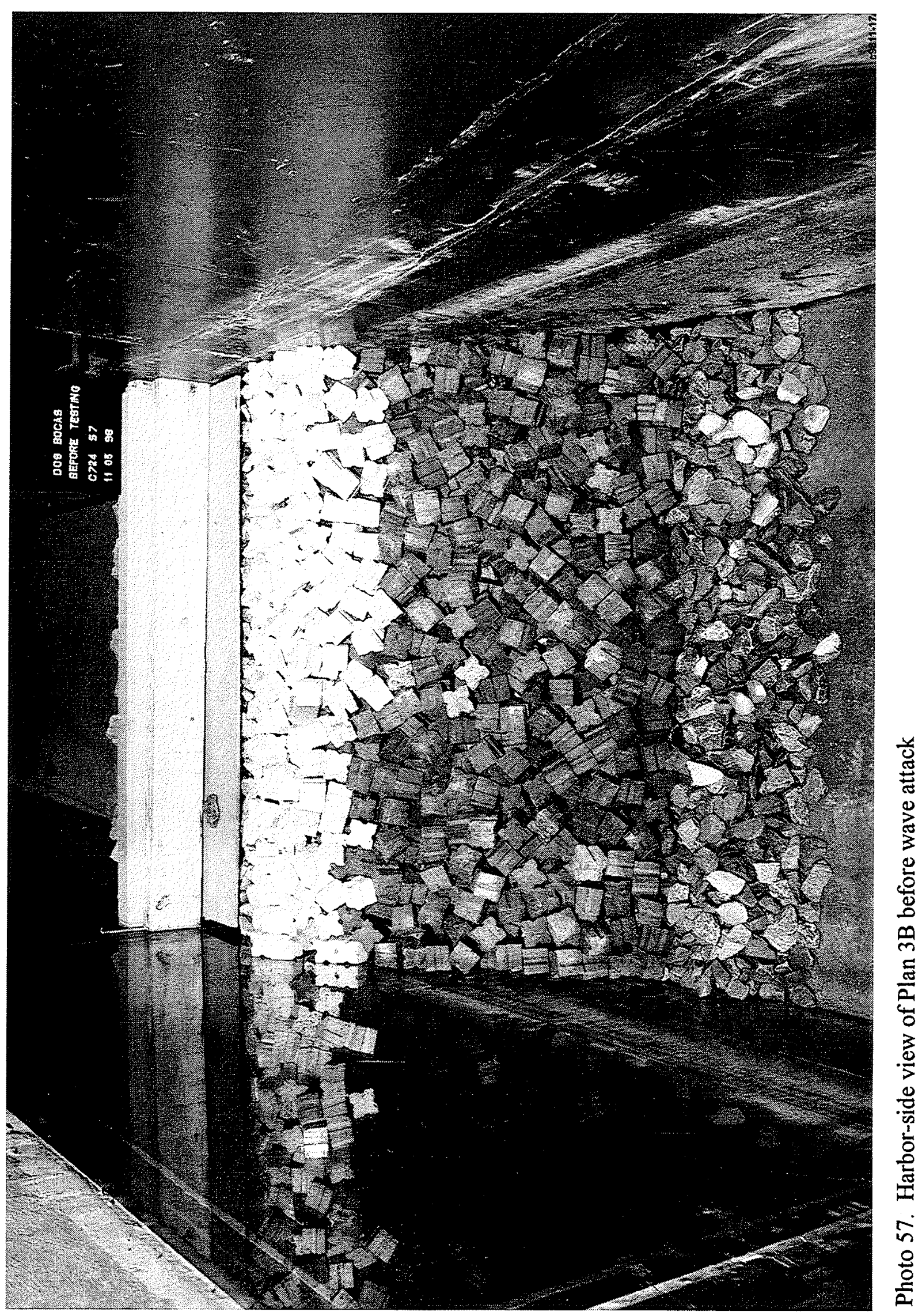



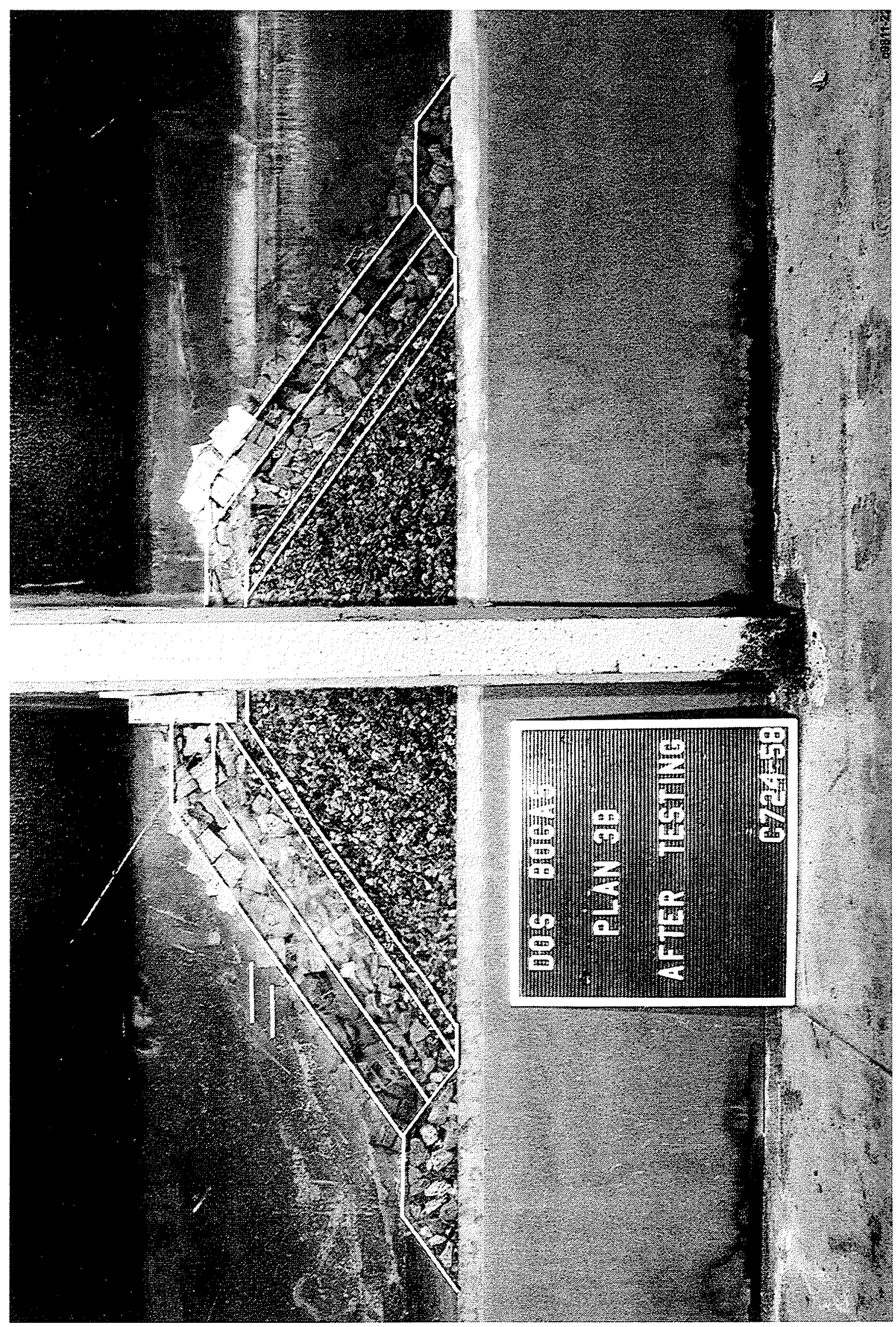

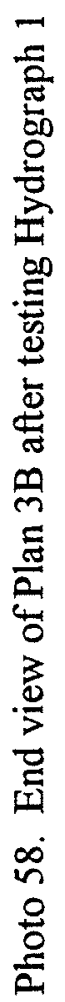




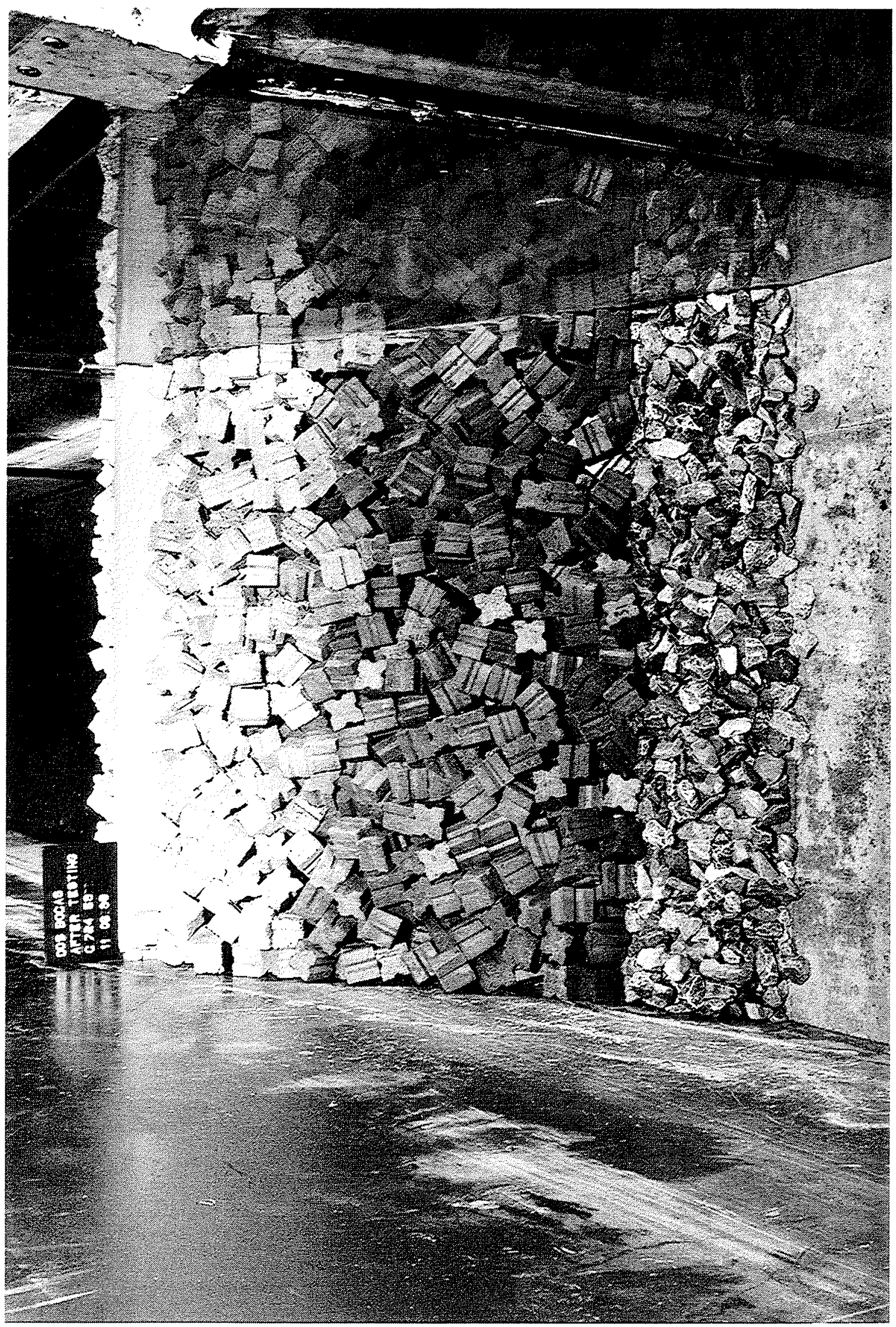

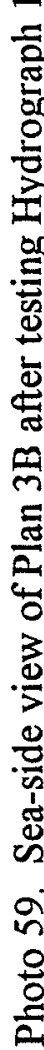




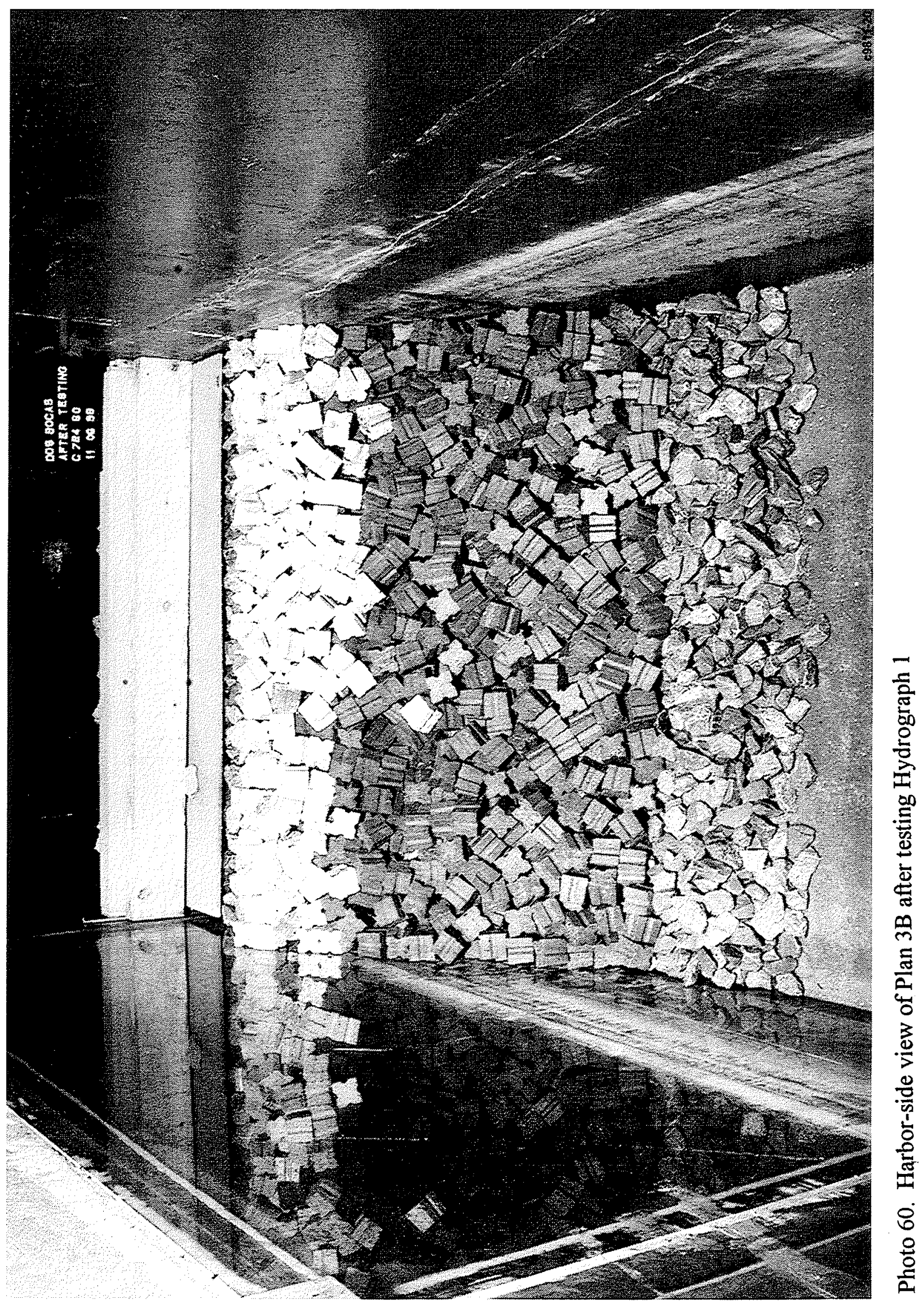



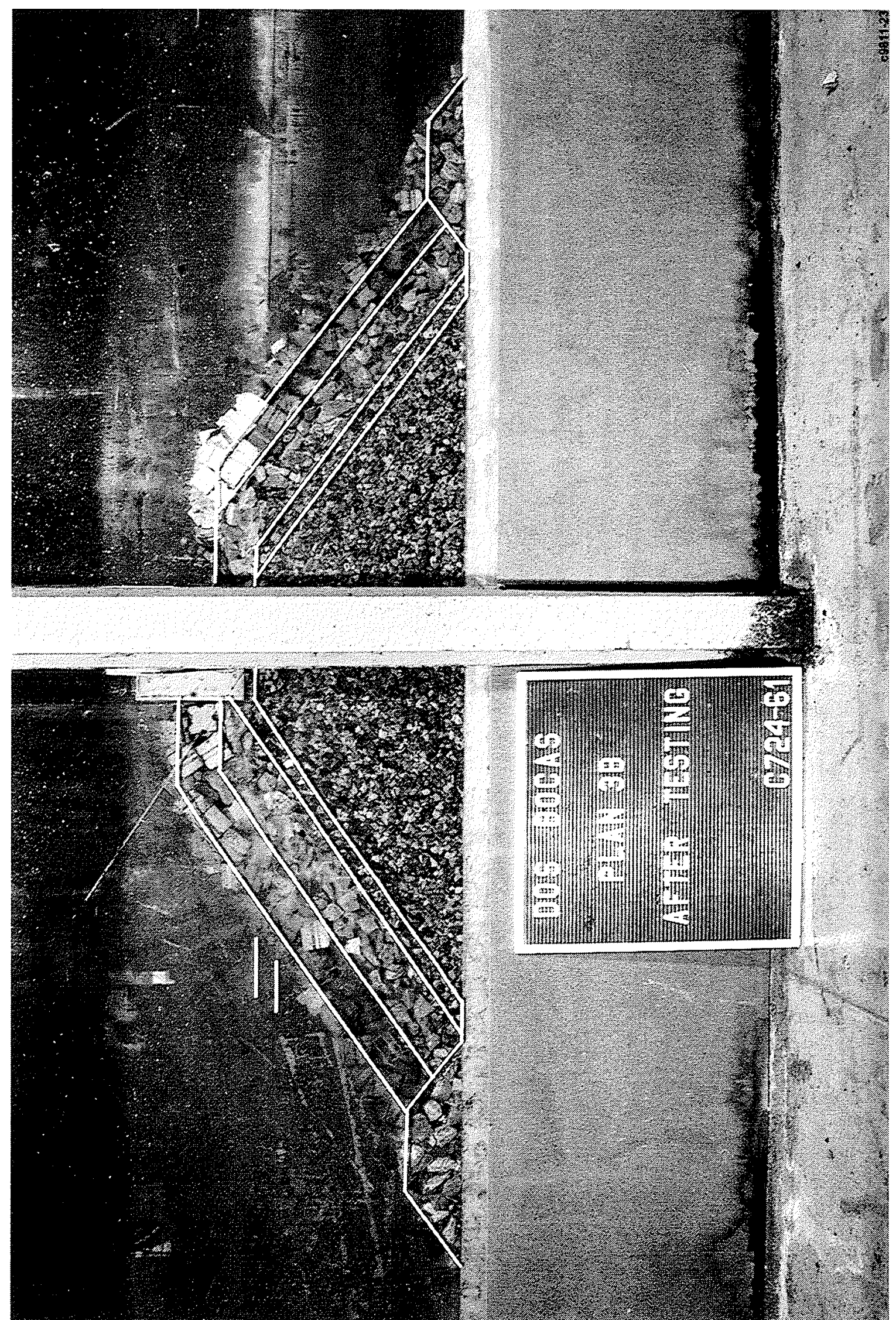

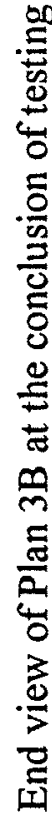

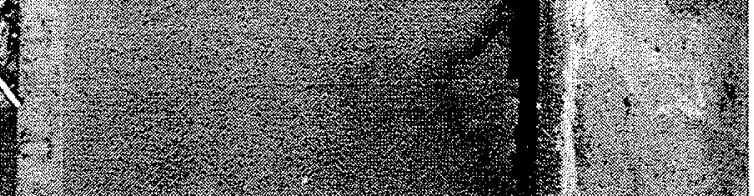

$\overline{0}$

융 


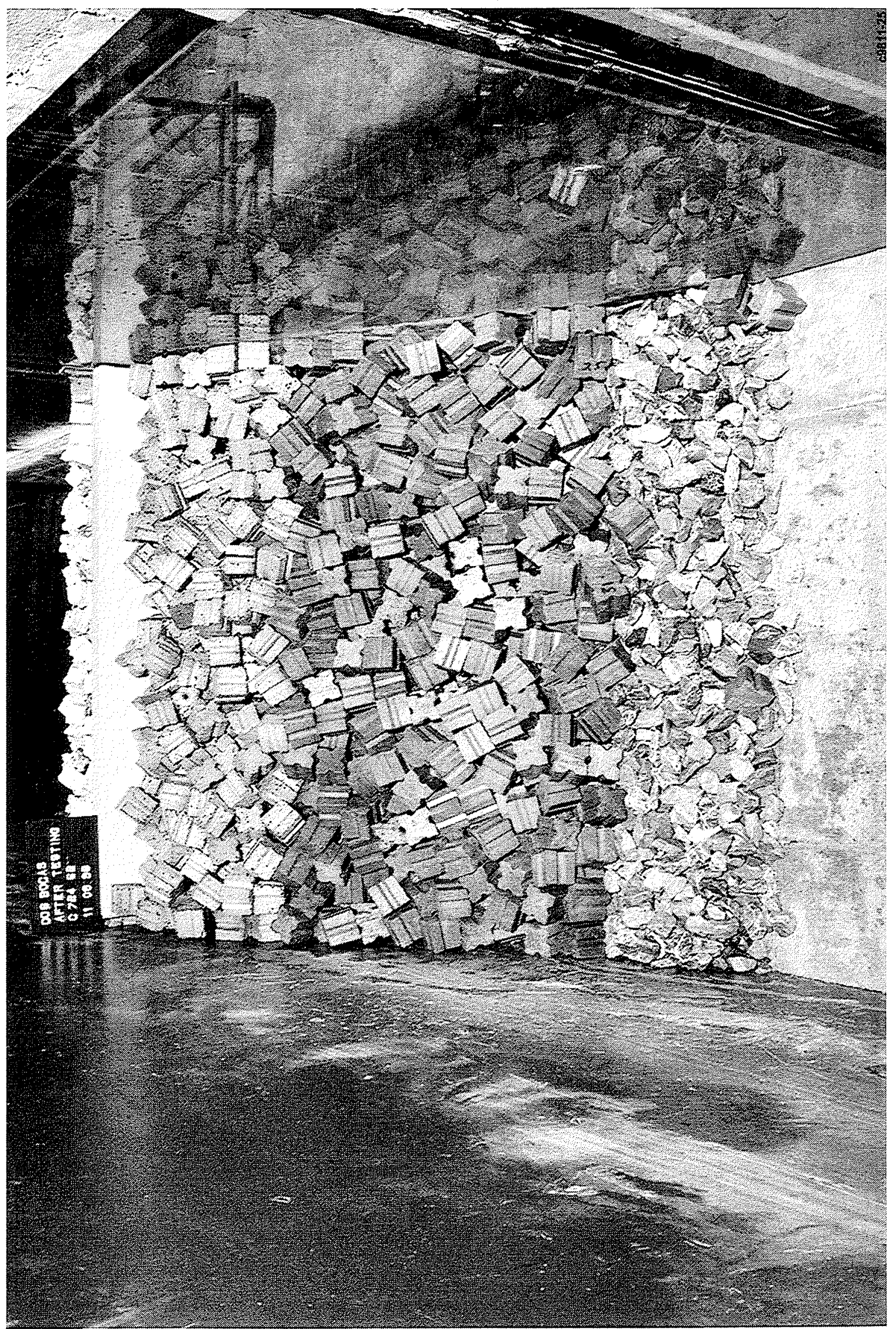

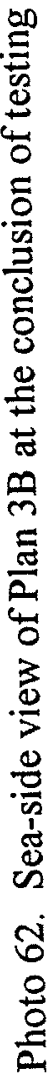




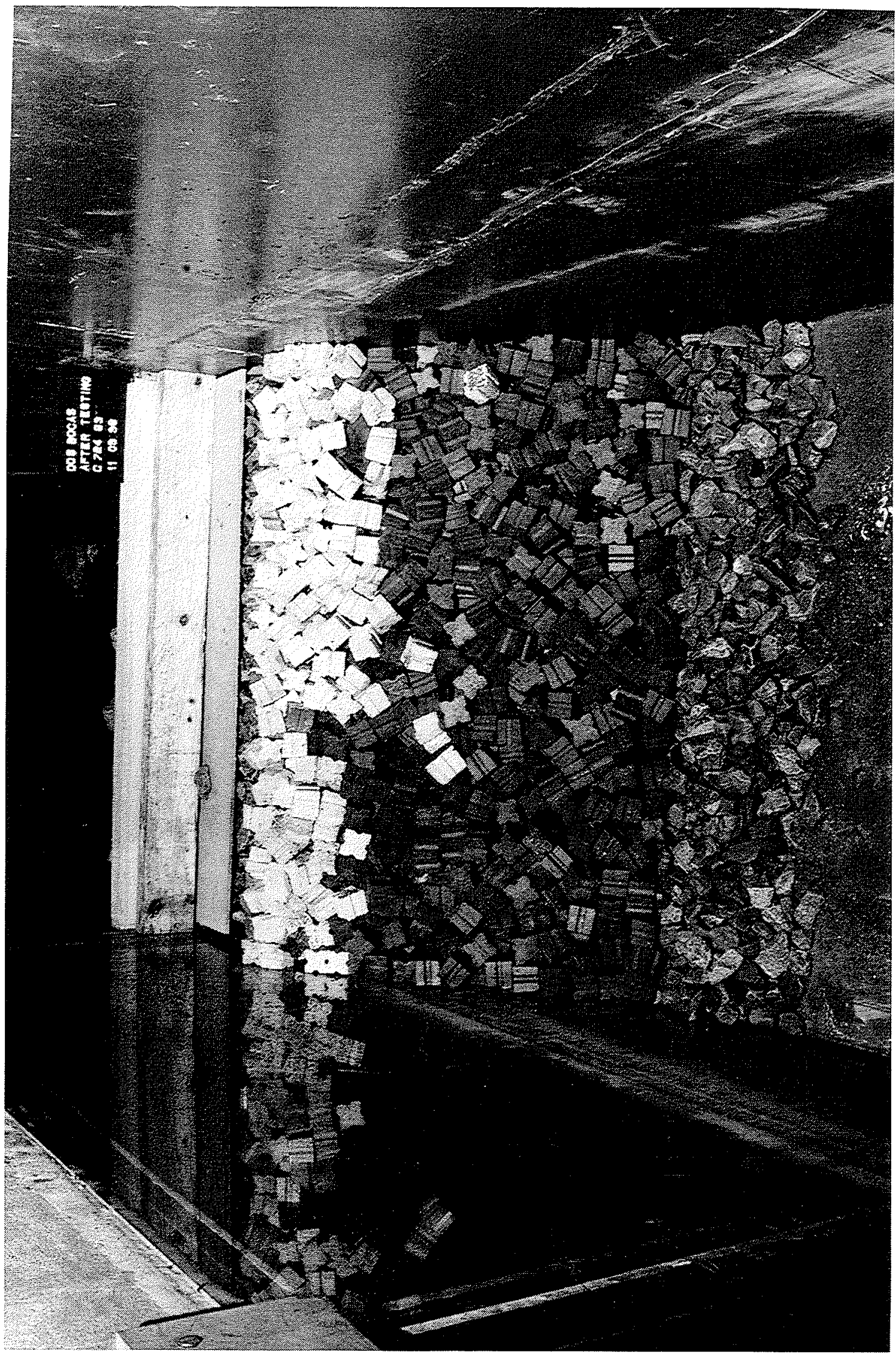

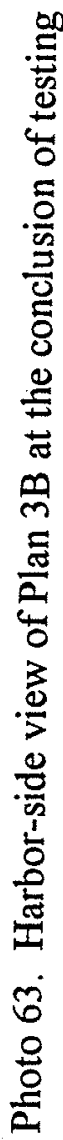



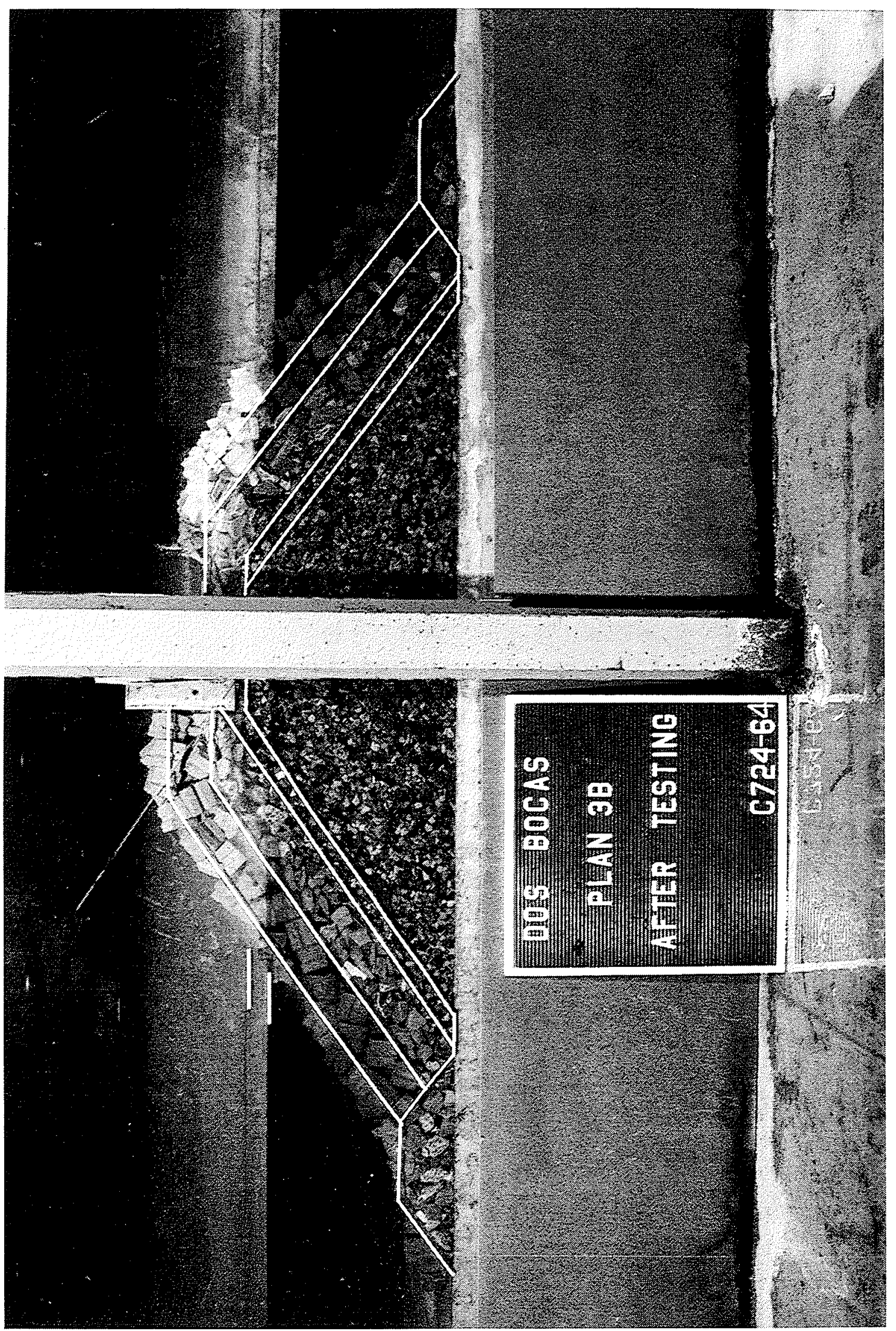

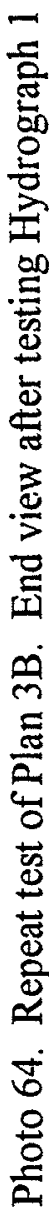




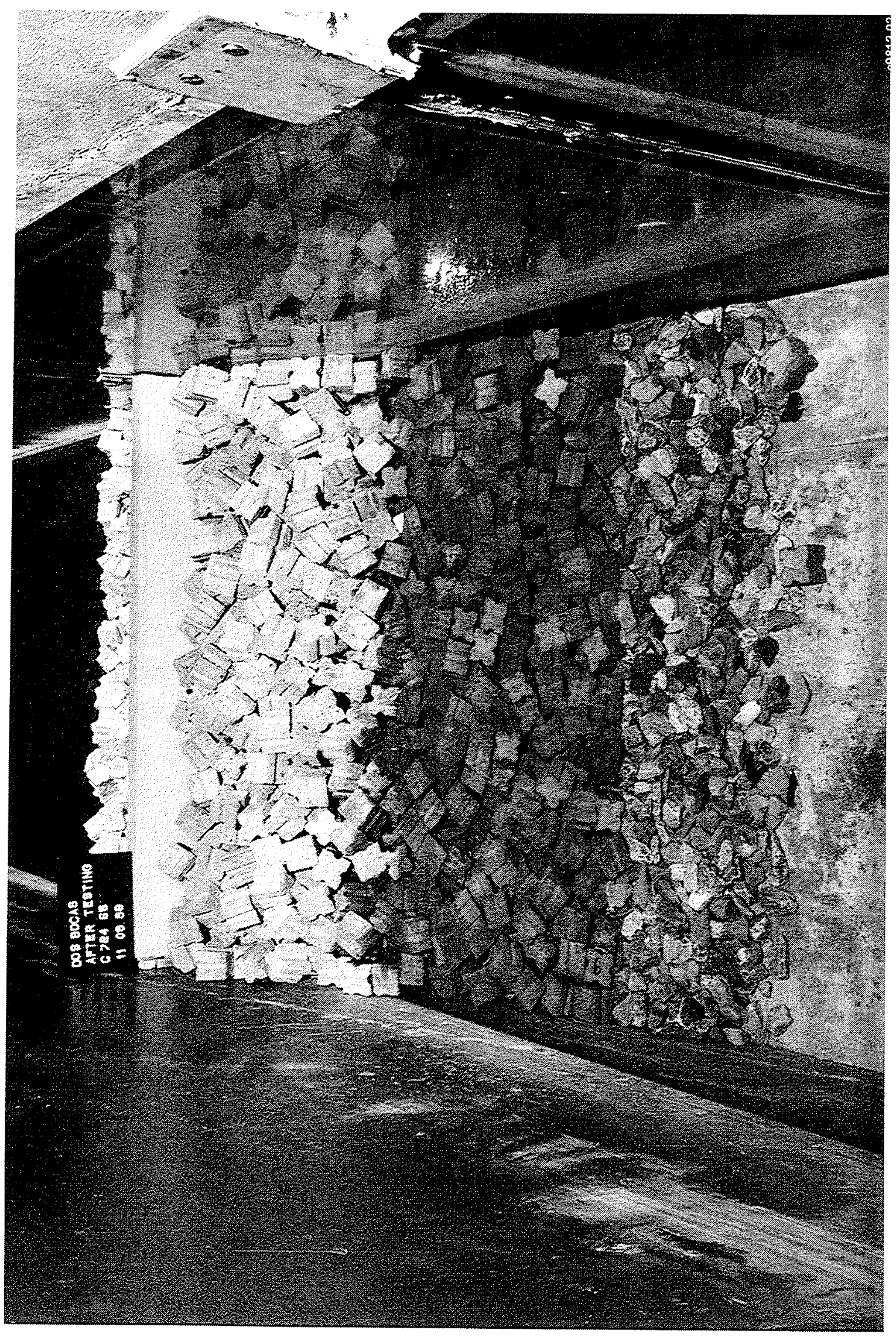

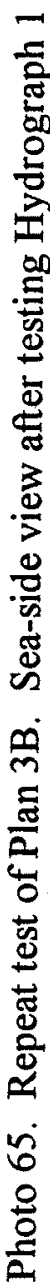




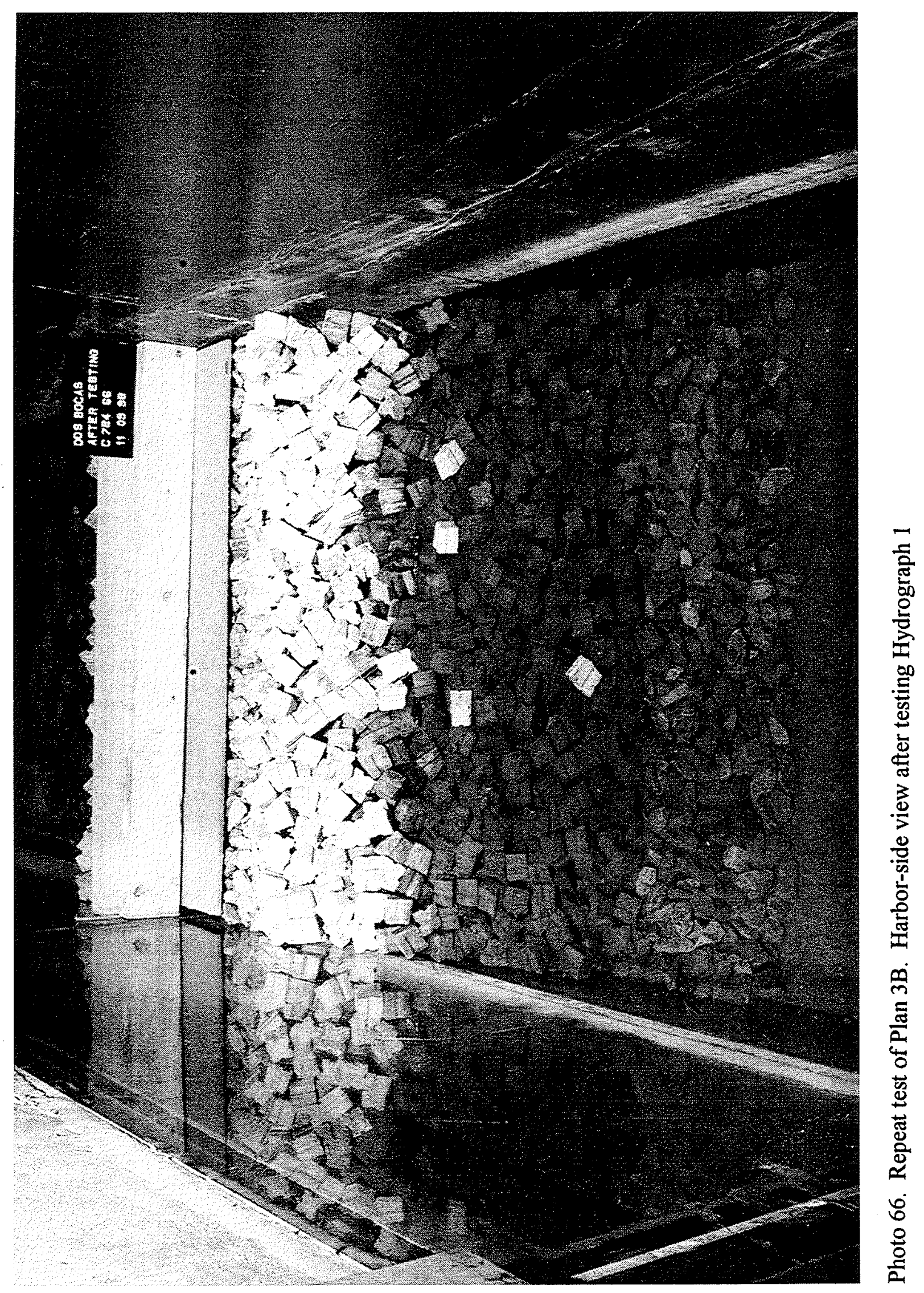



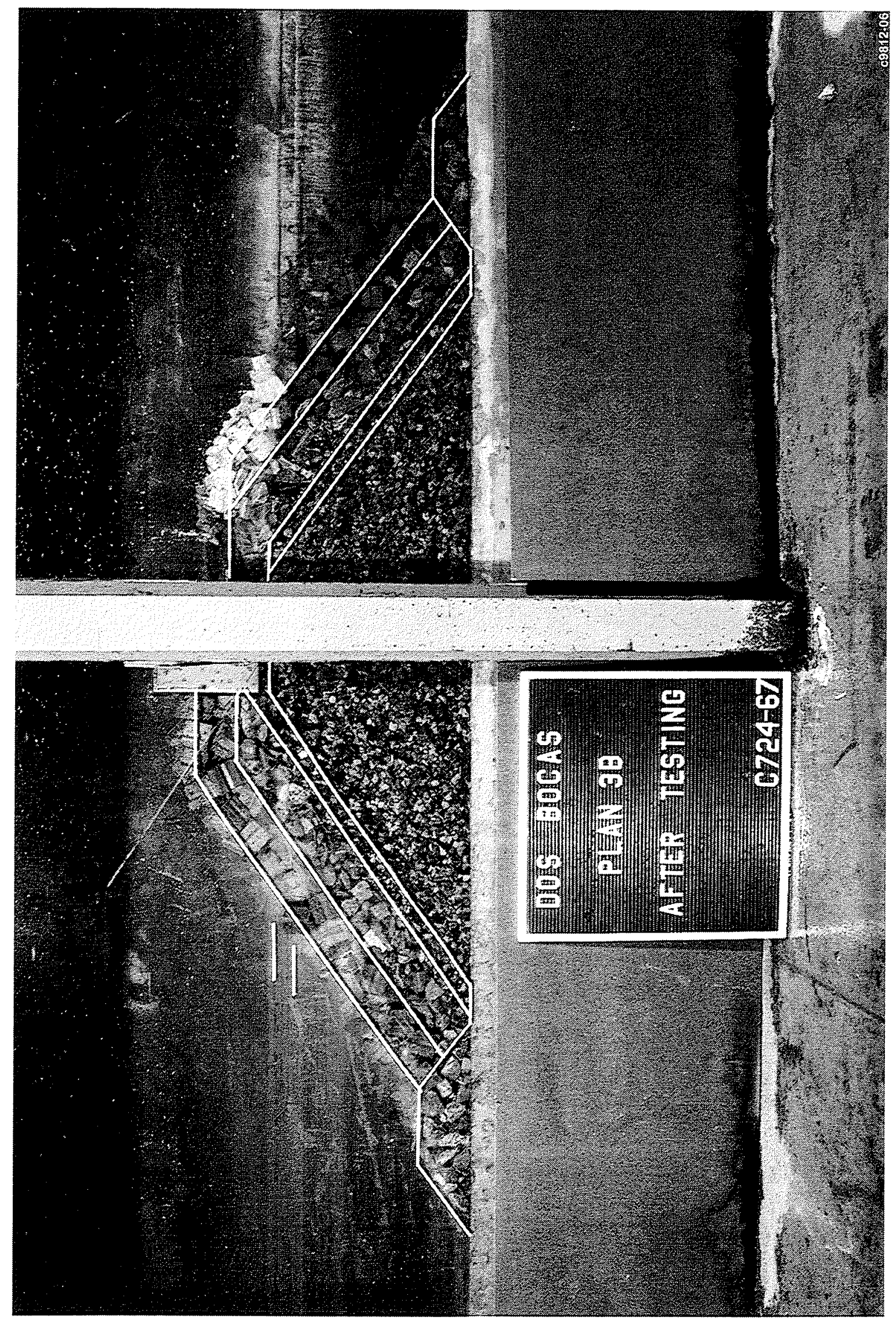

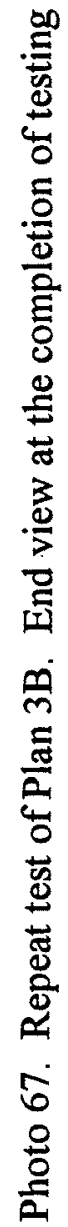




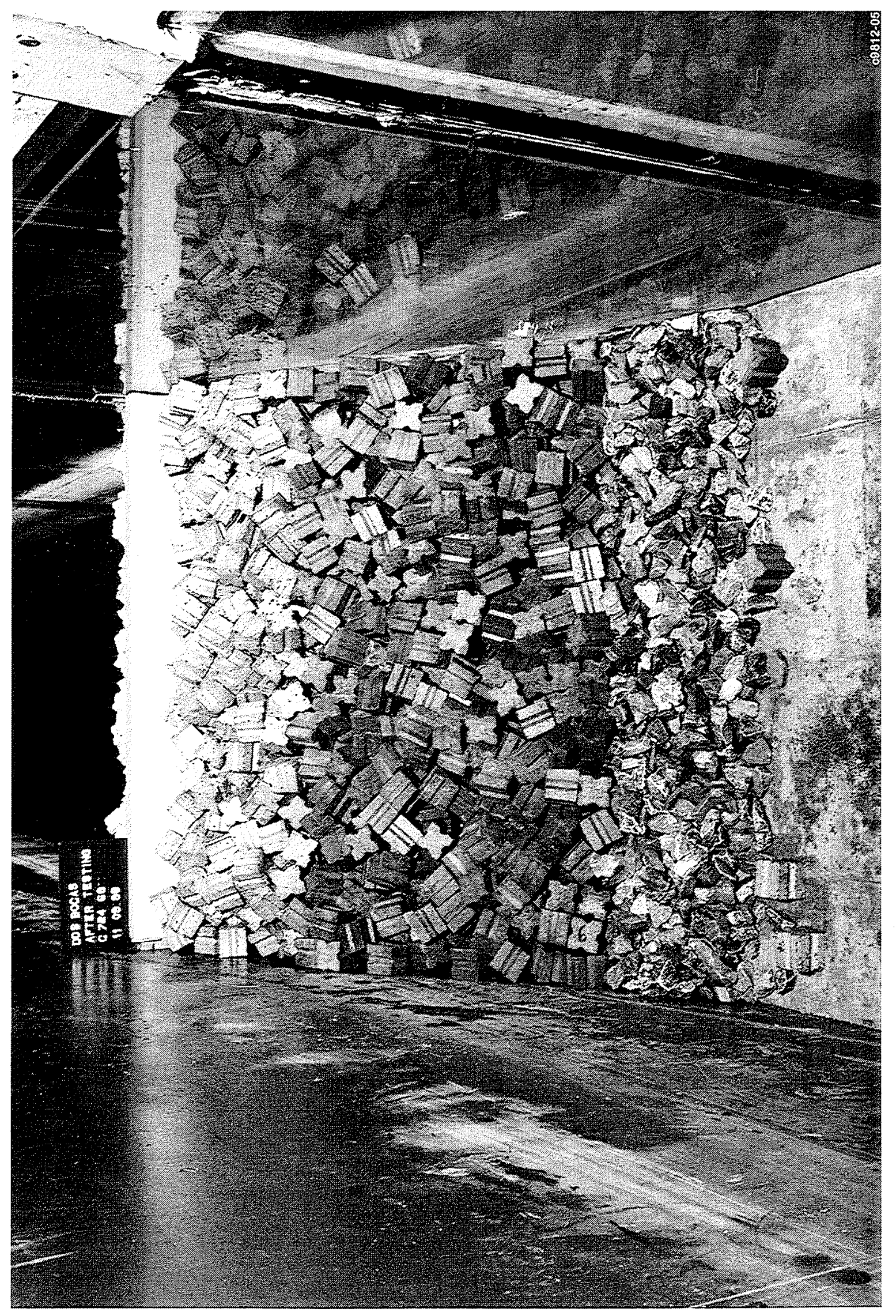

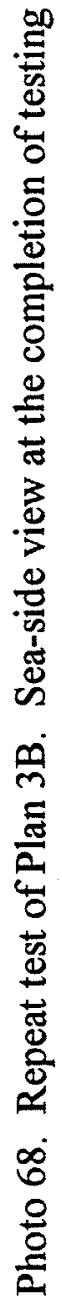




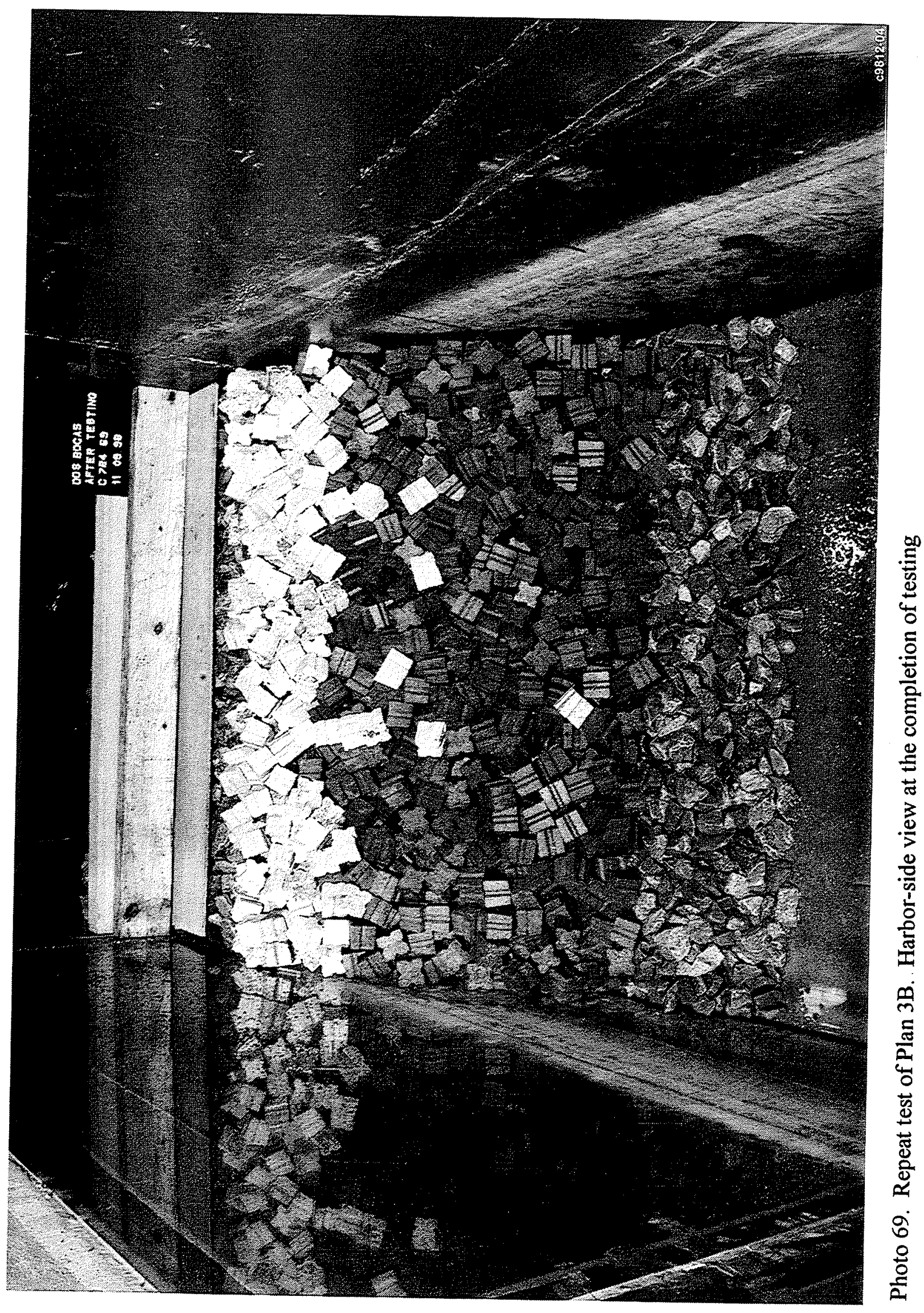



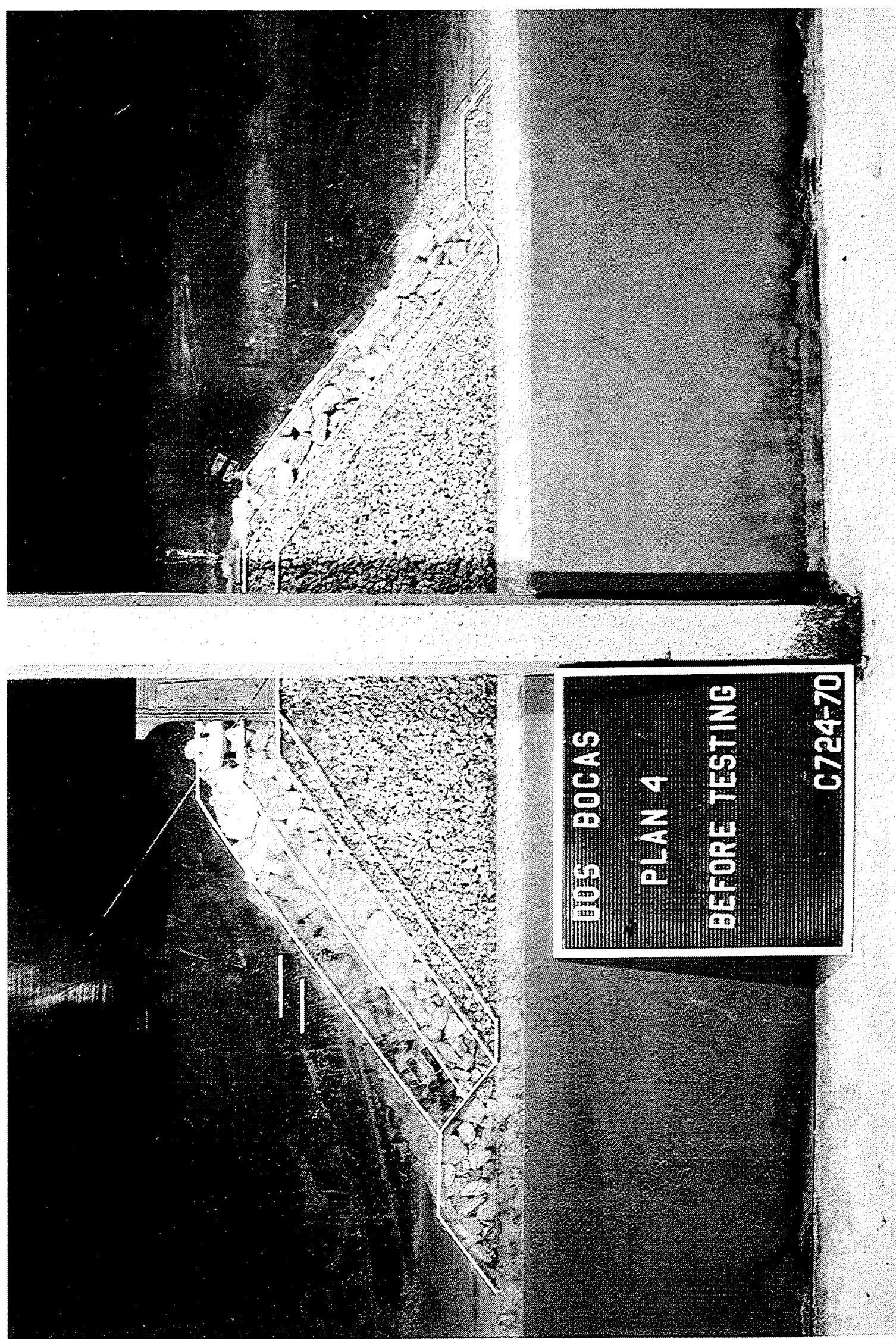

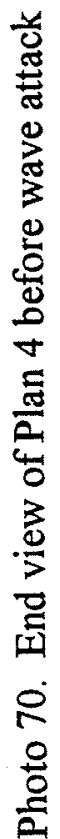




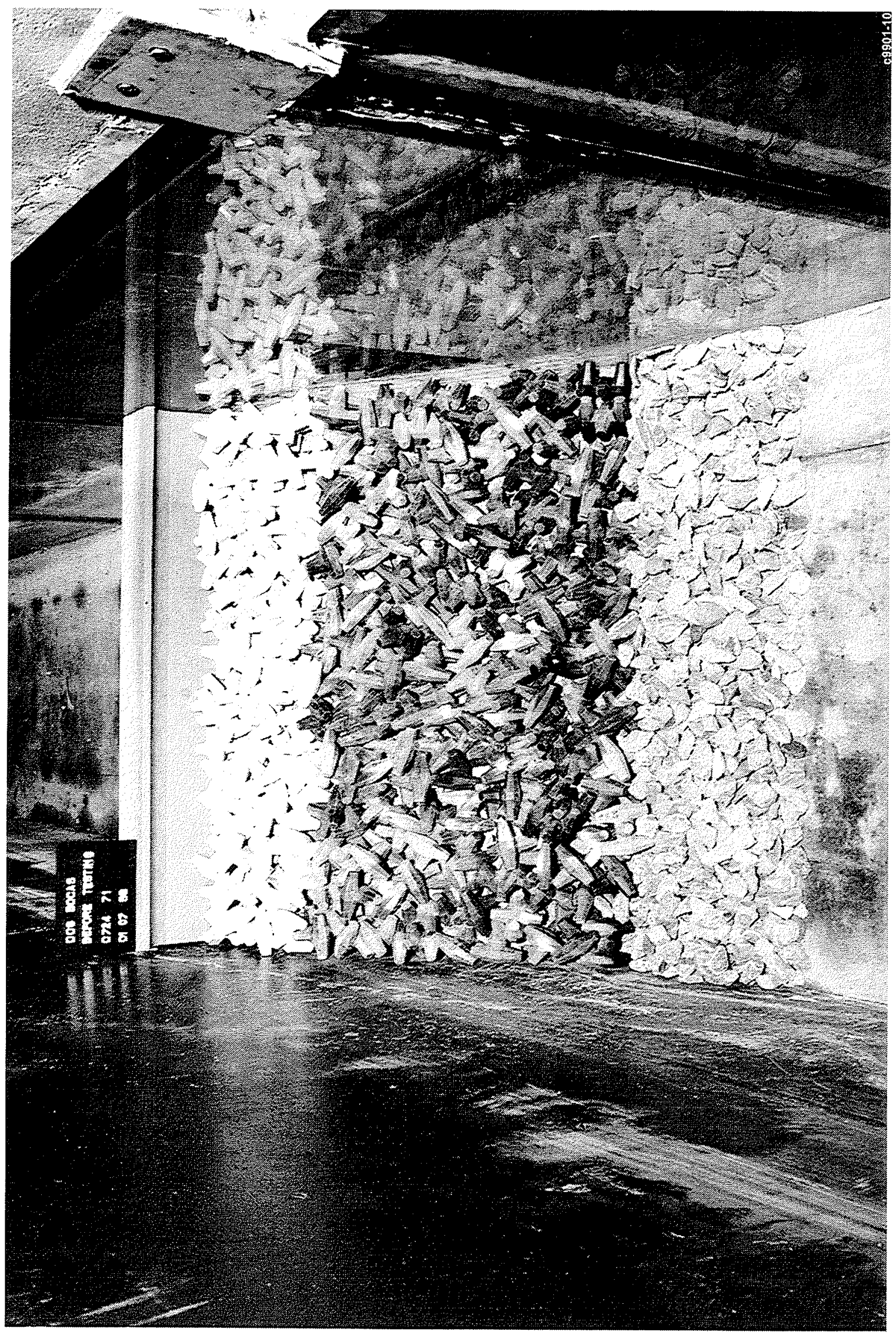

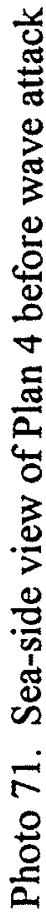




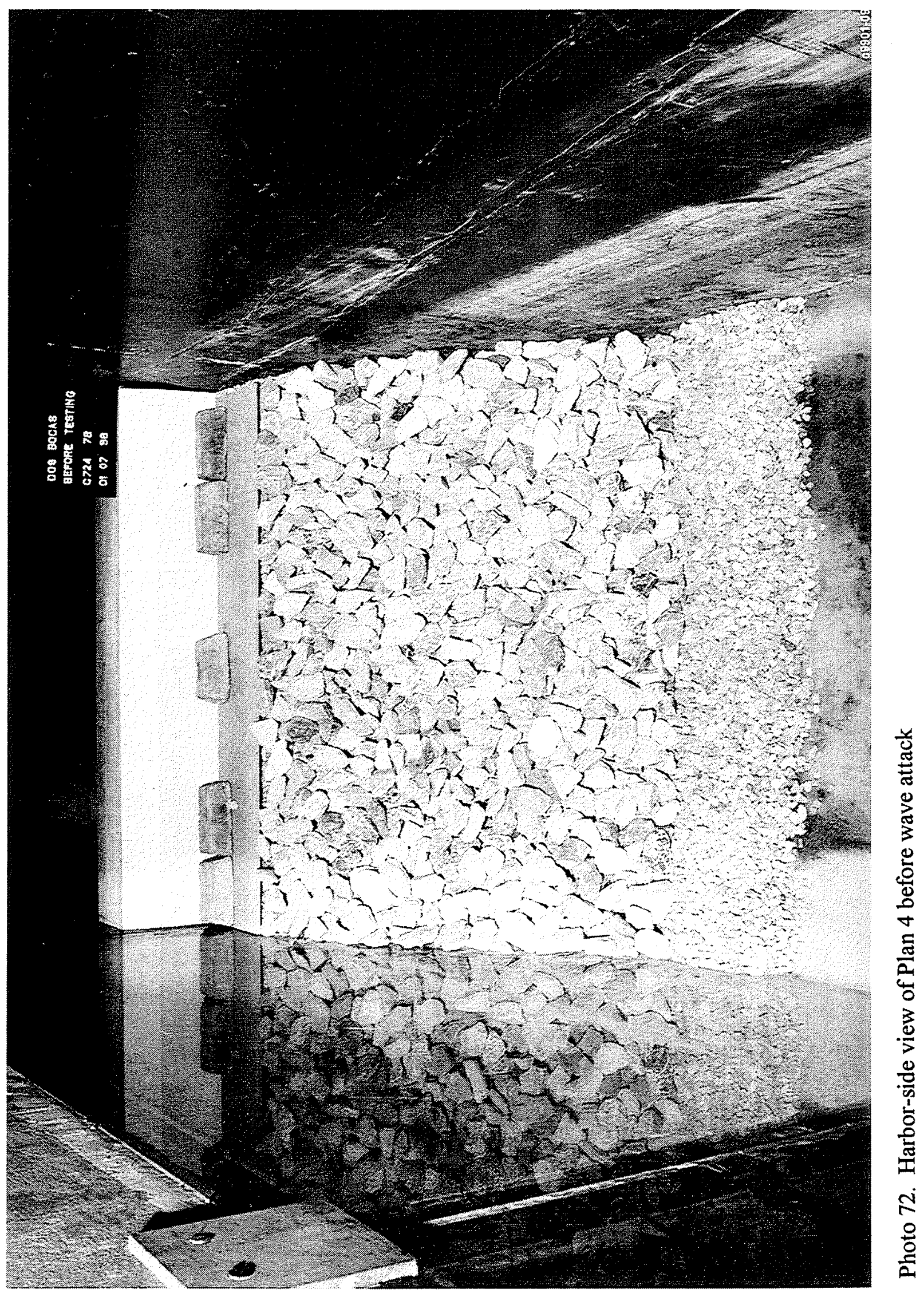



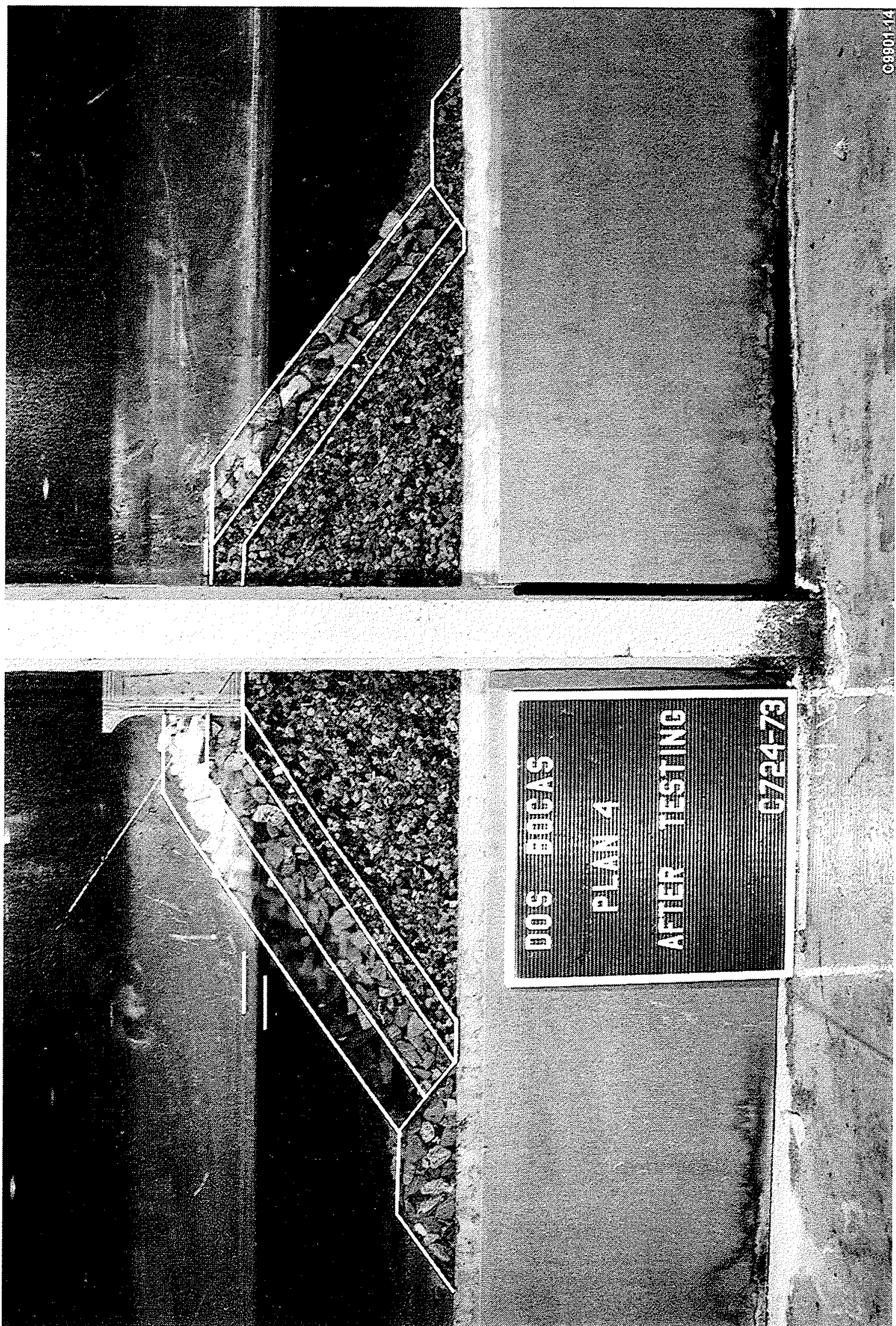

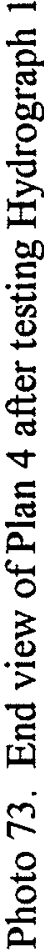




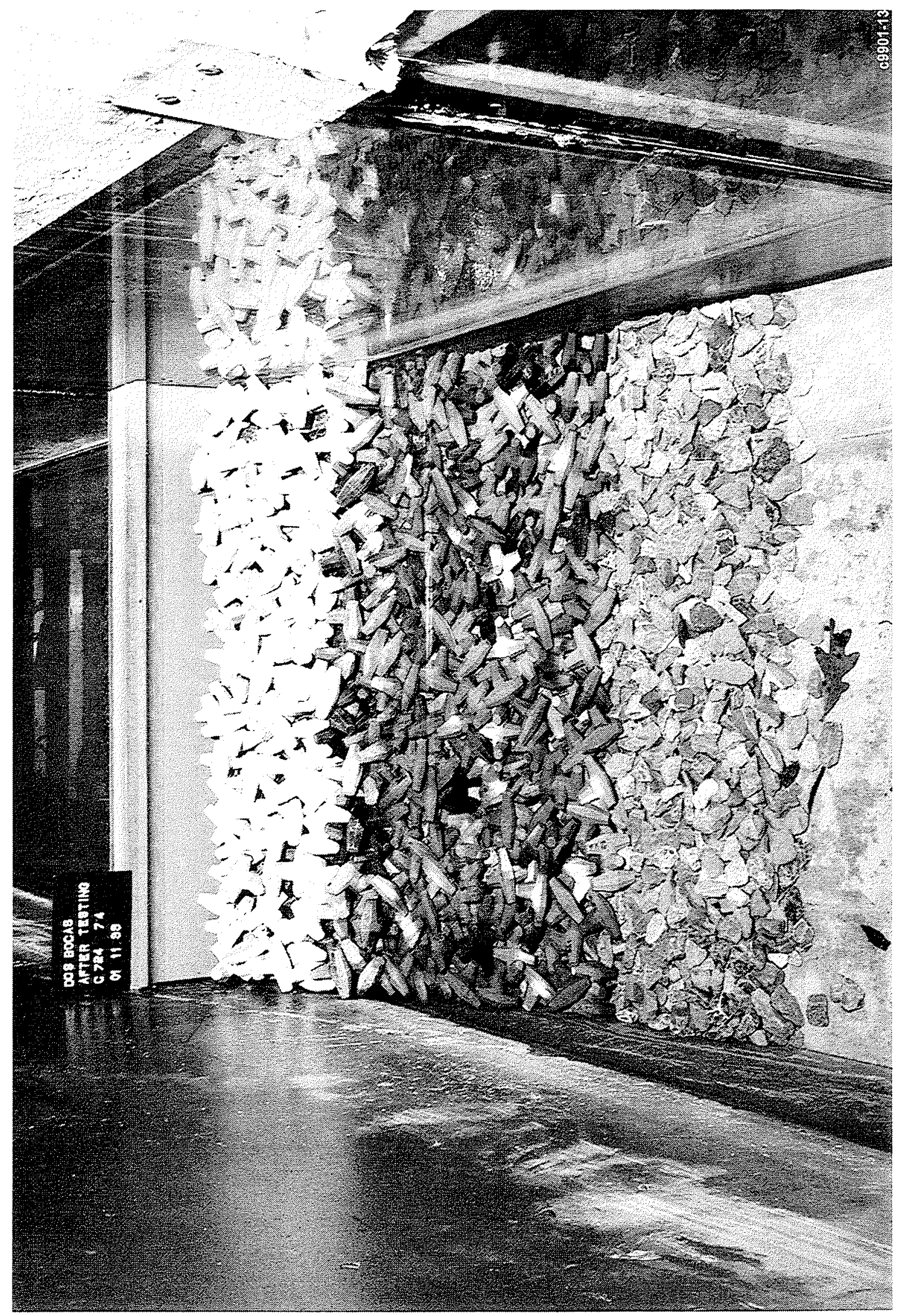

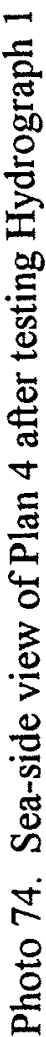




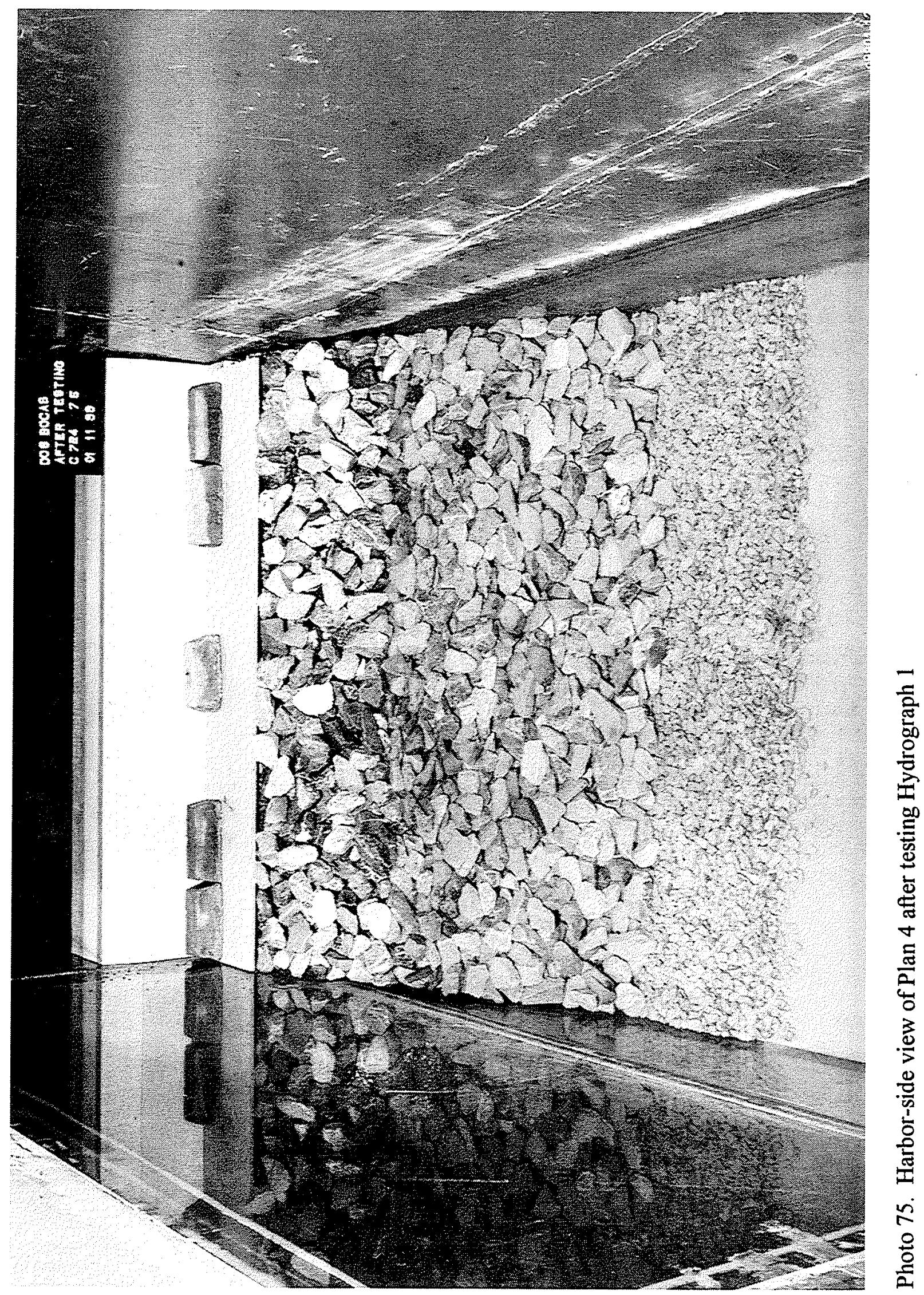



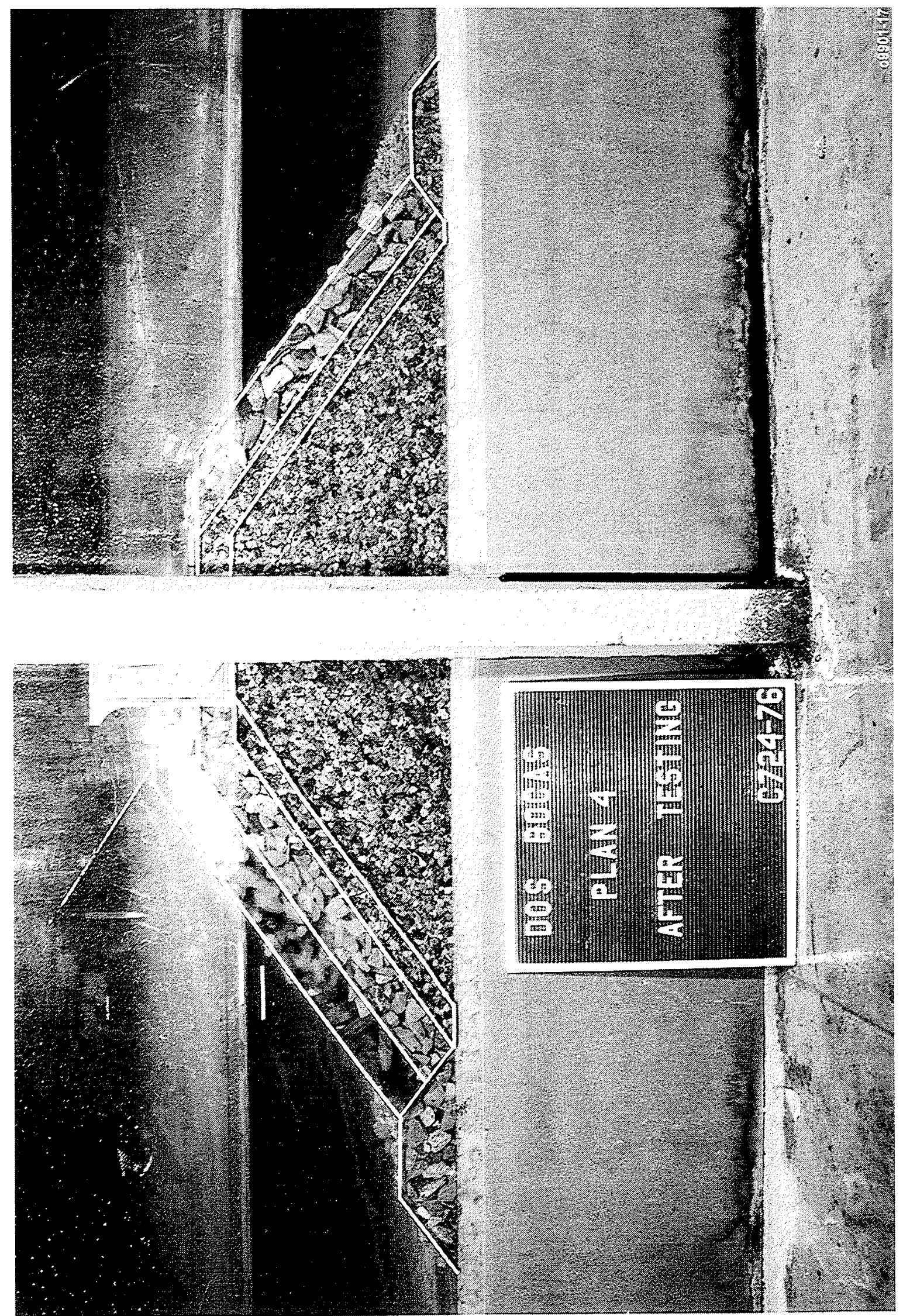

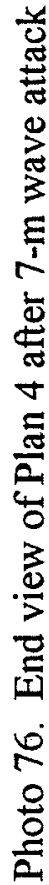




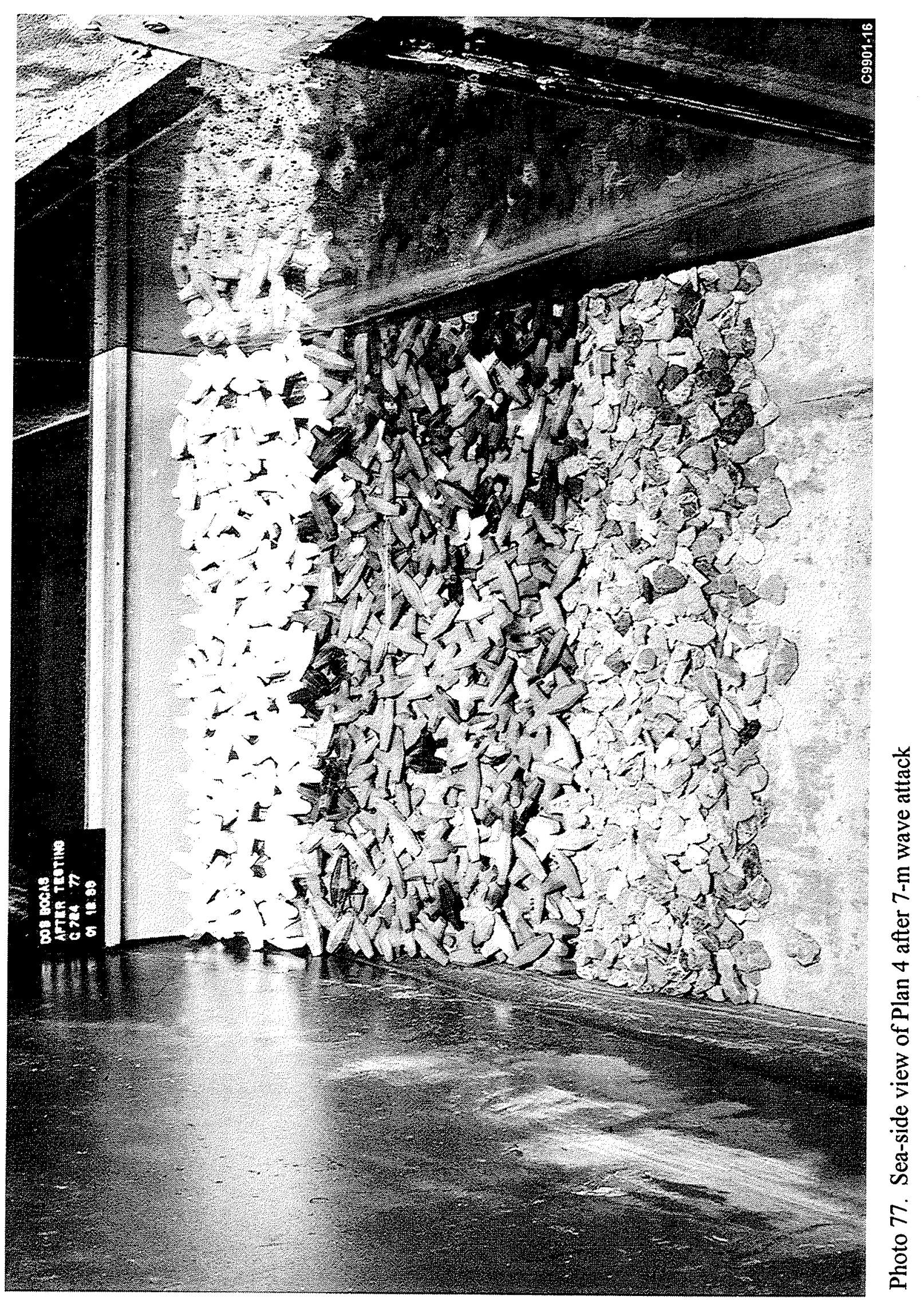




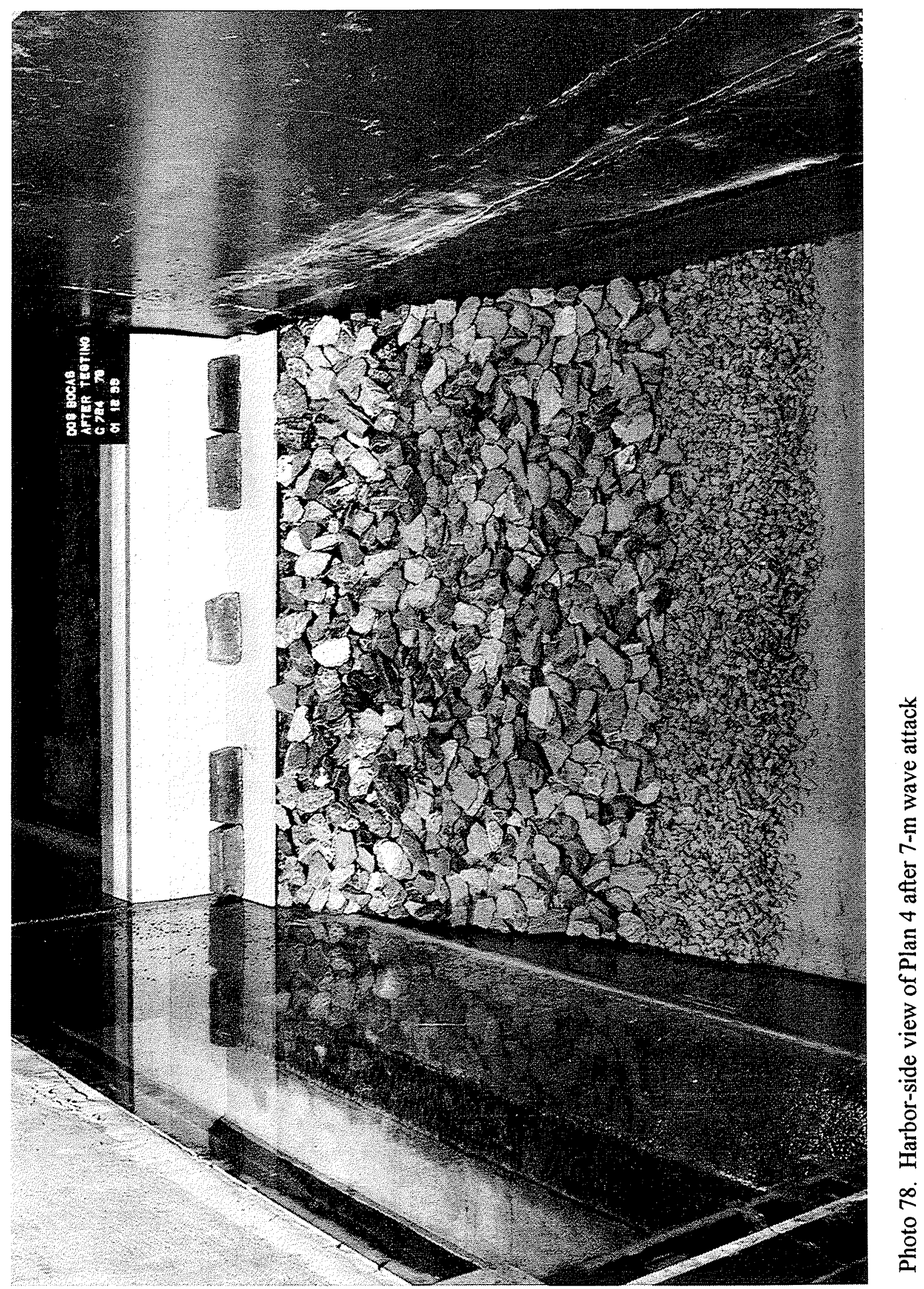



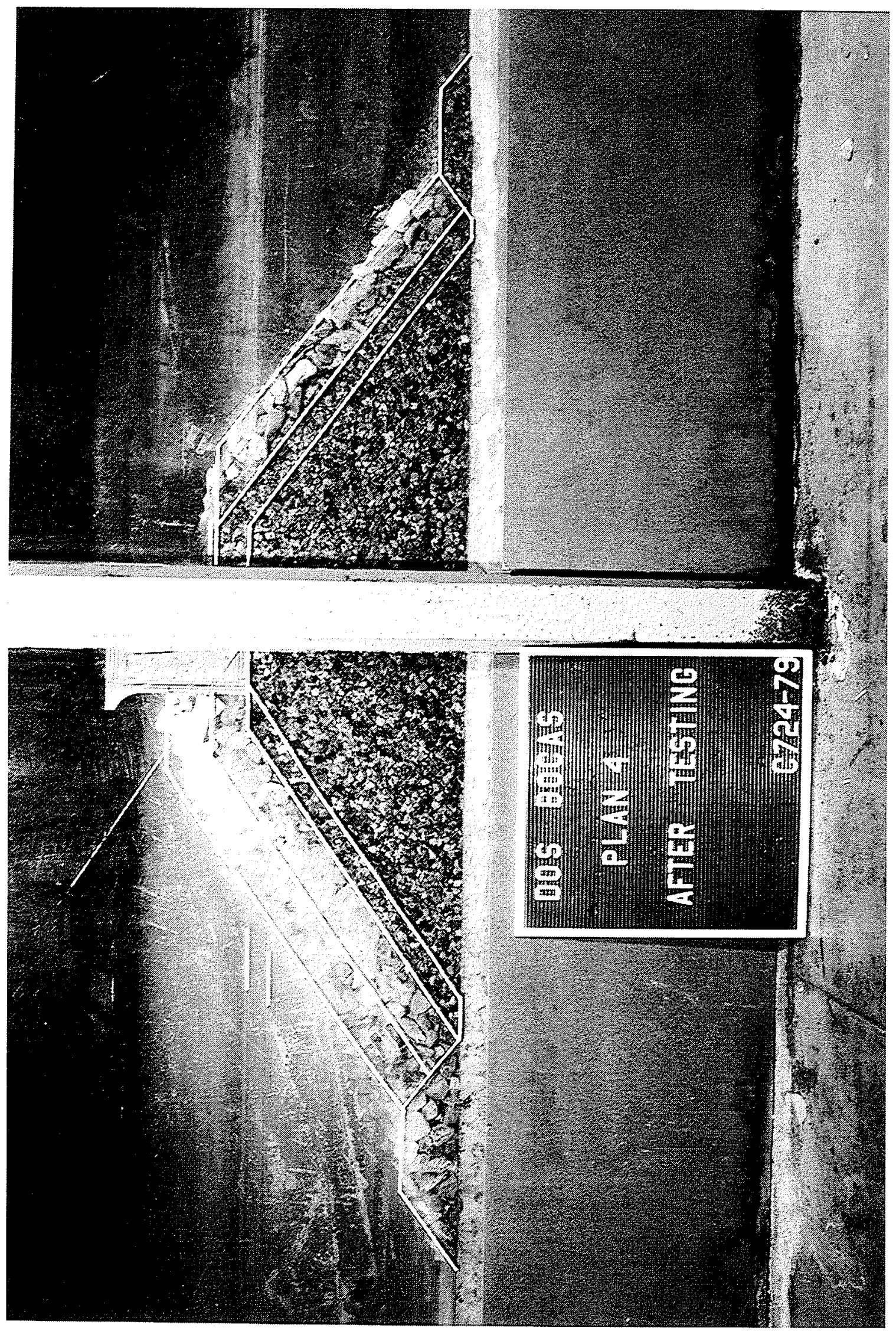

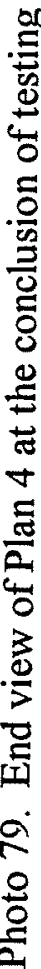




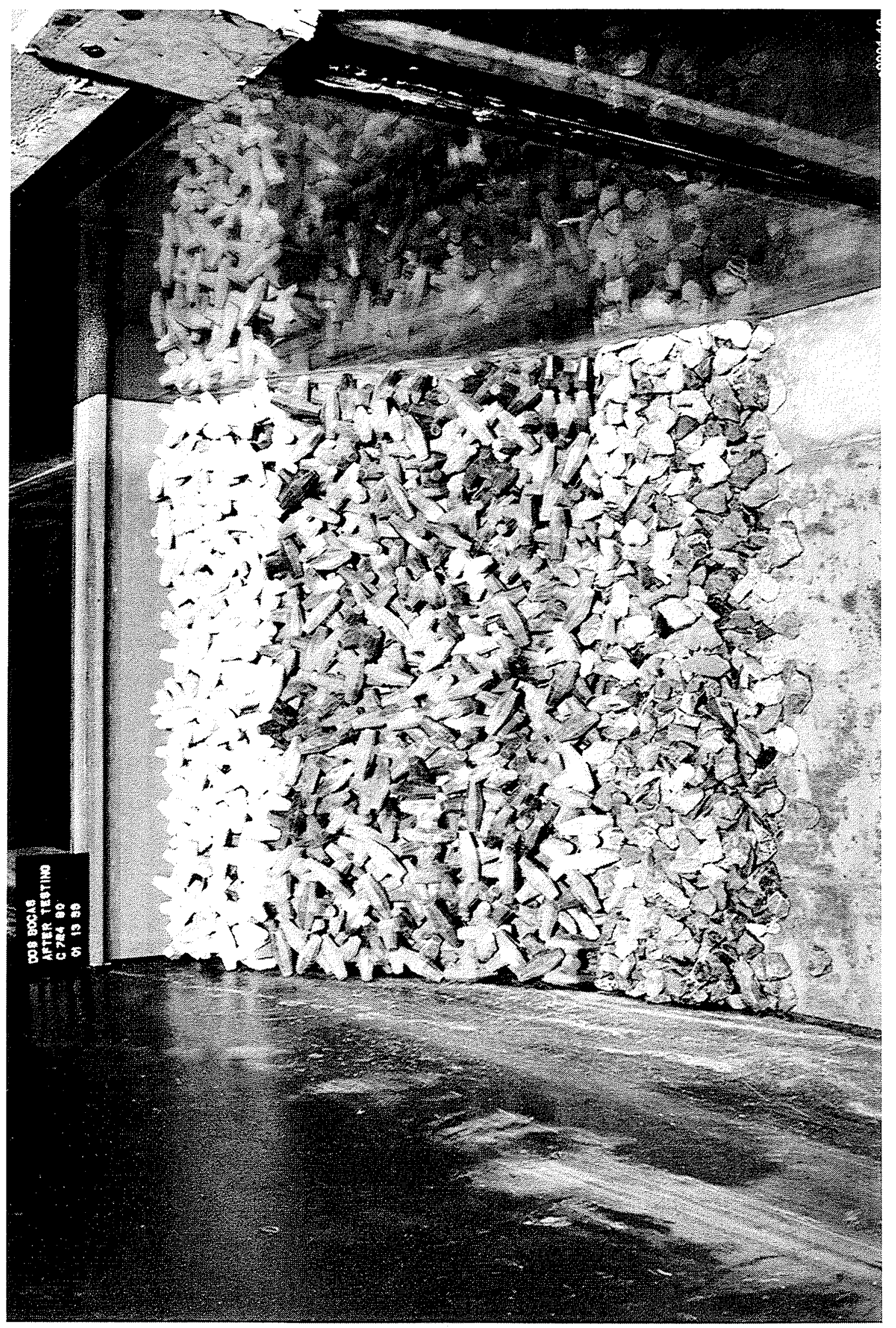

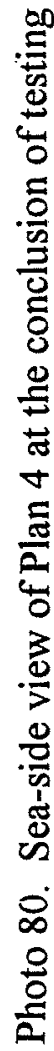




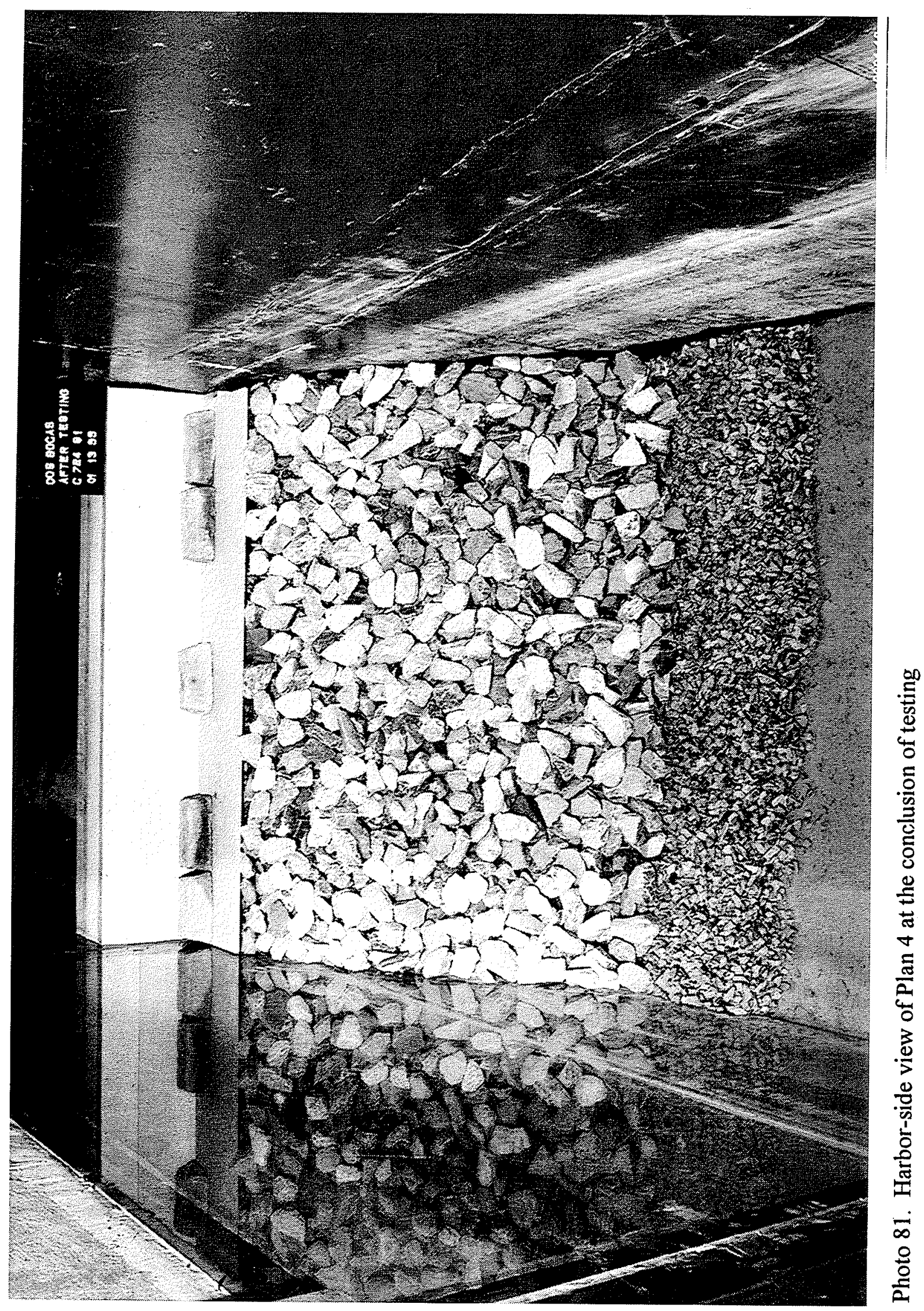




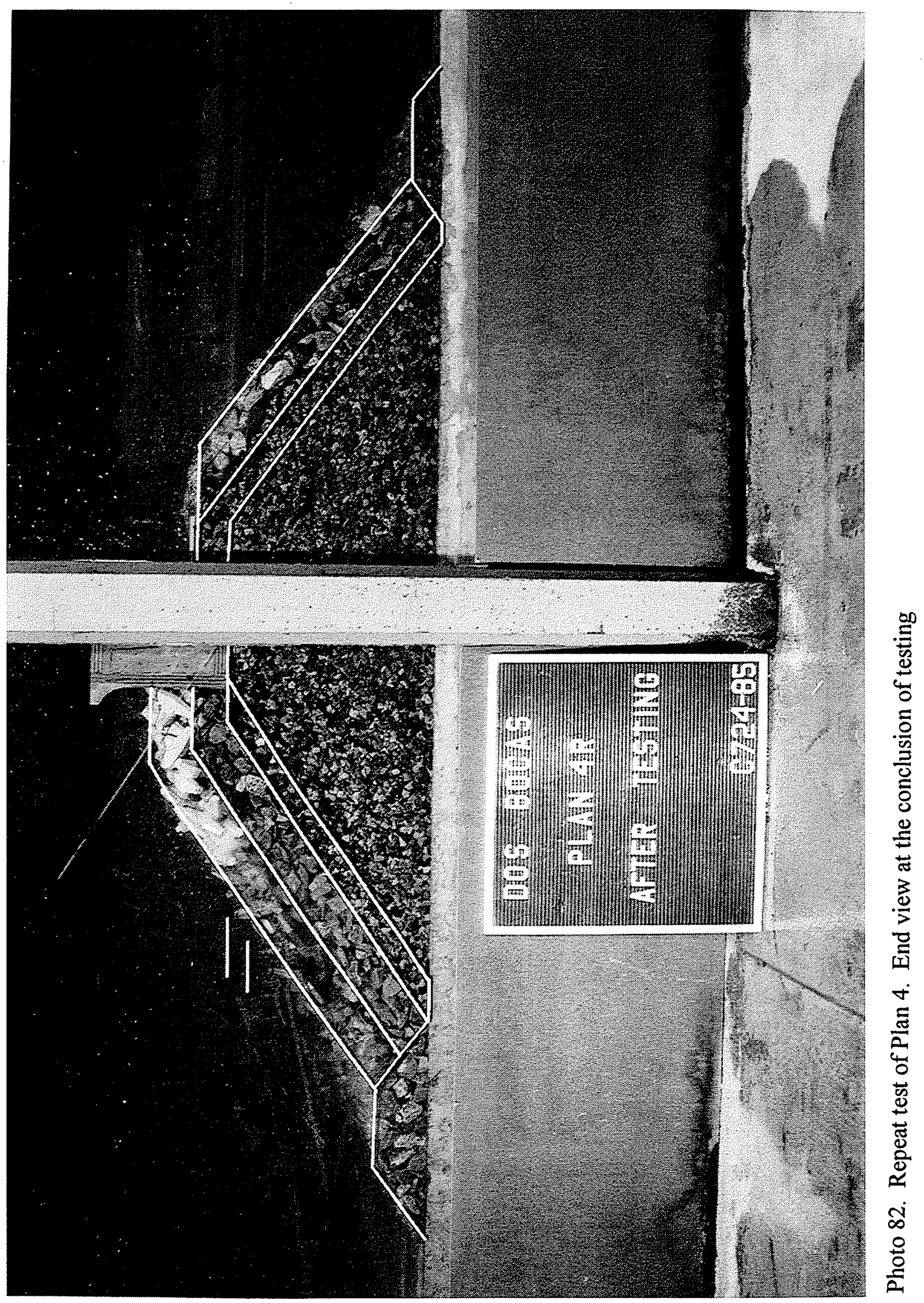




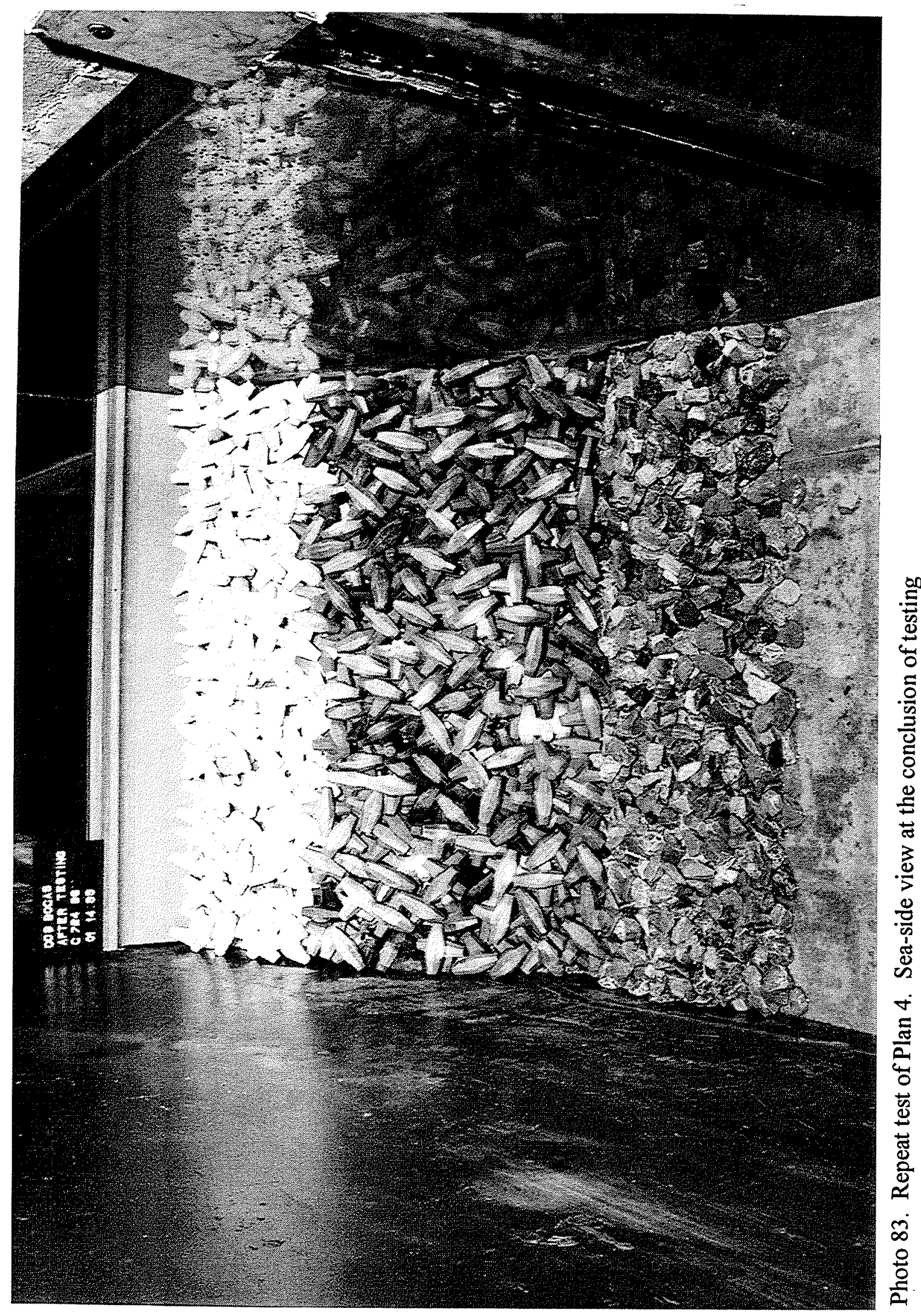




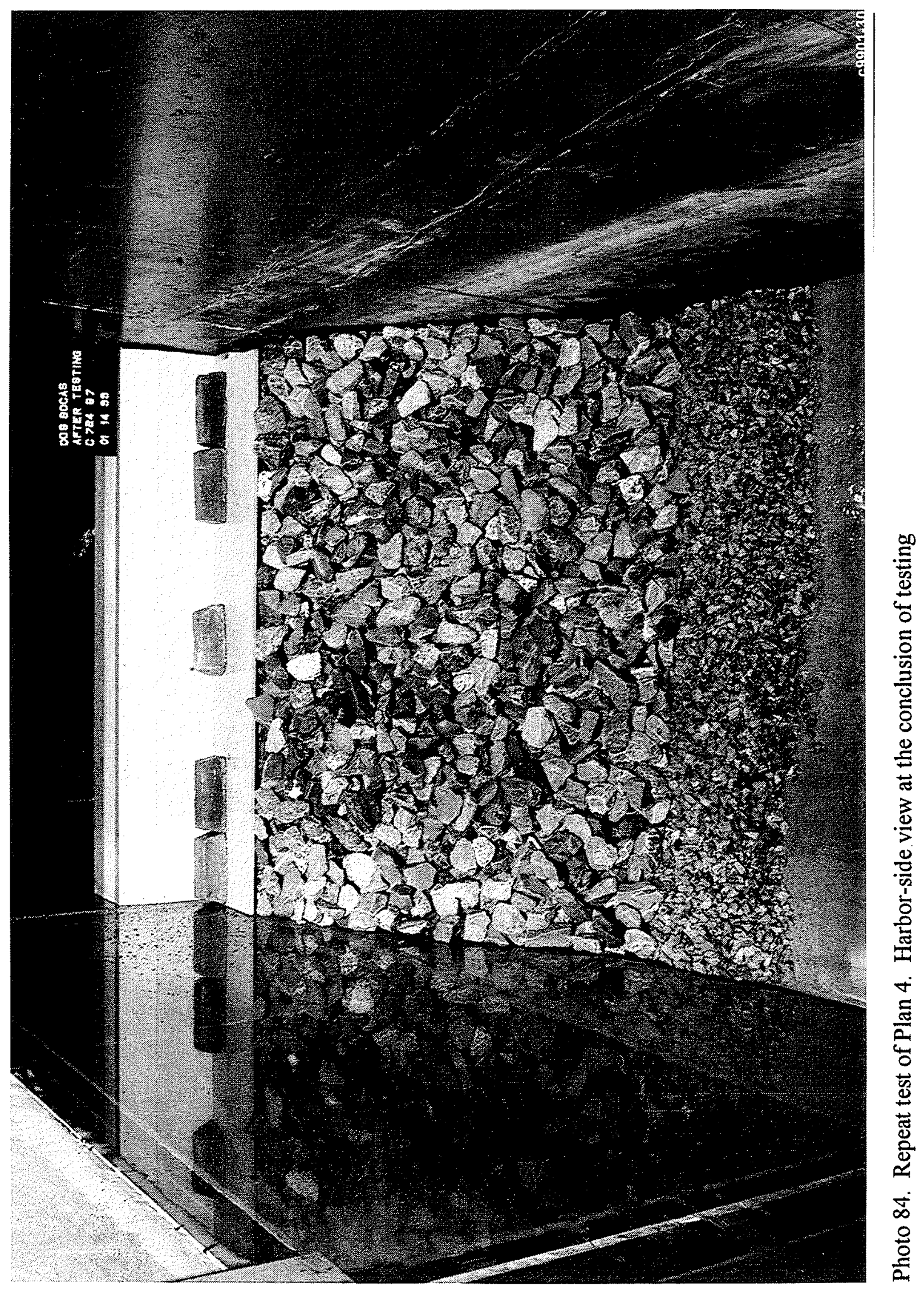



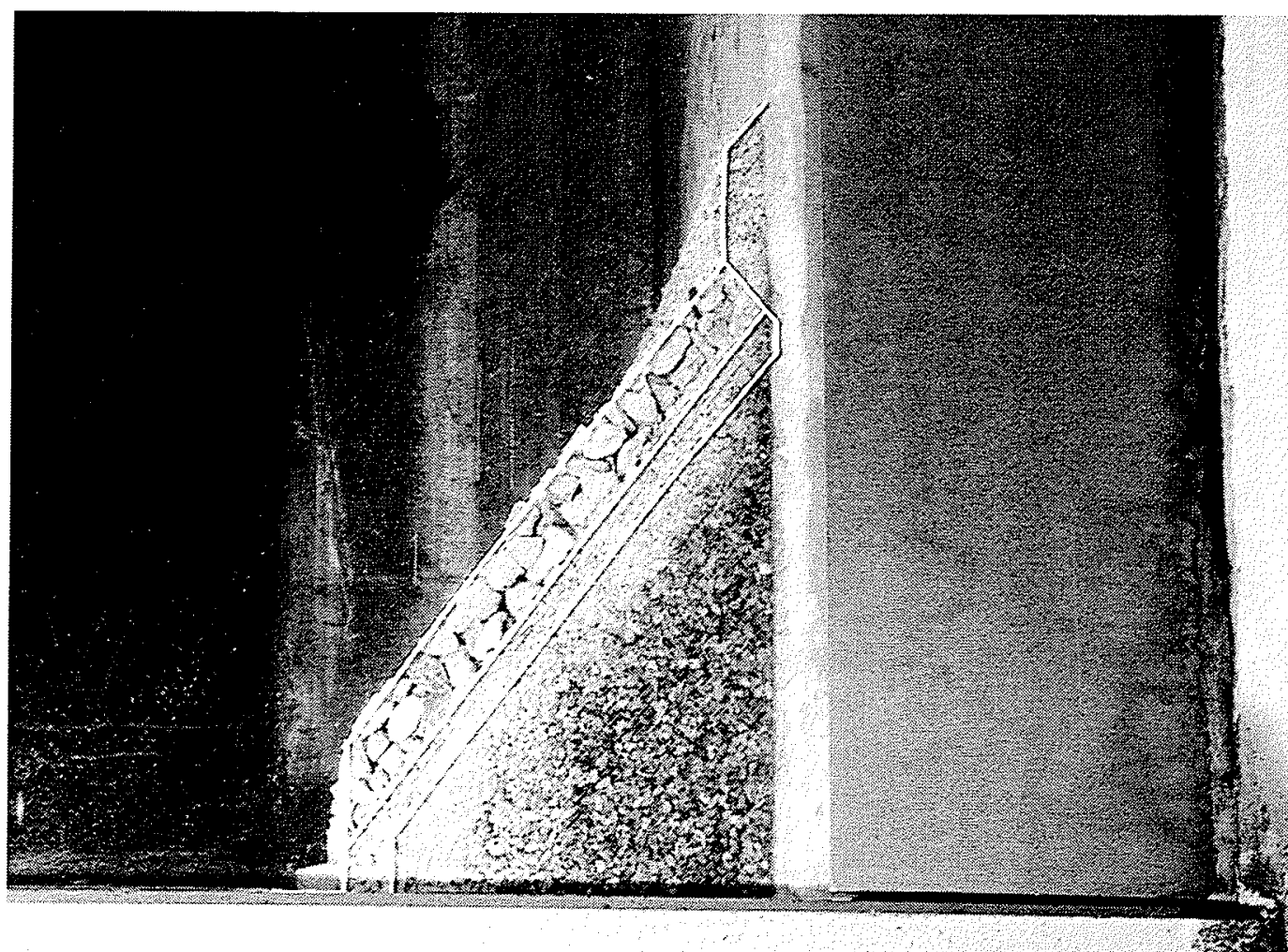

3

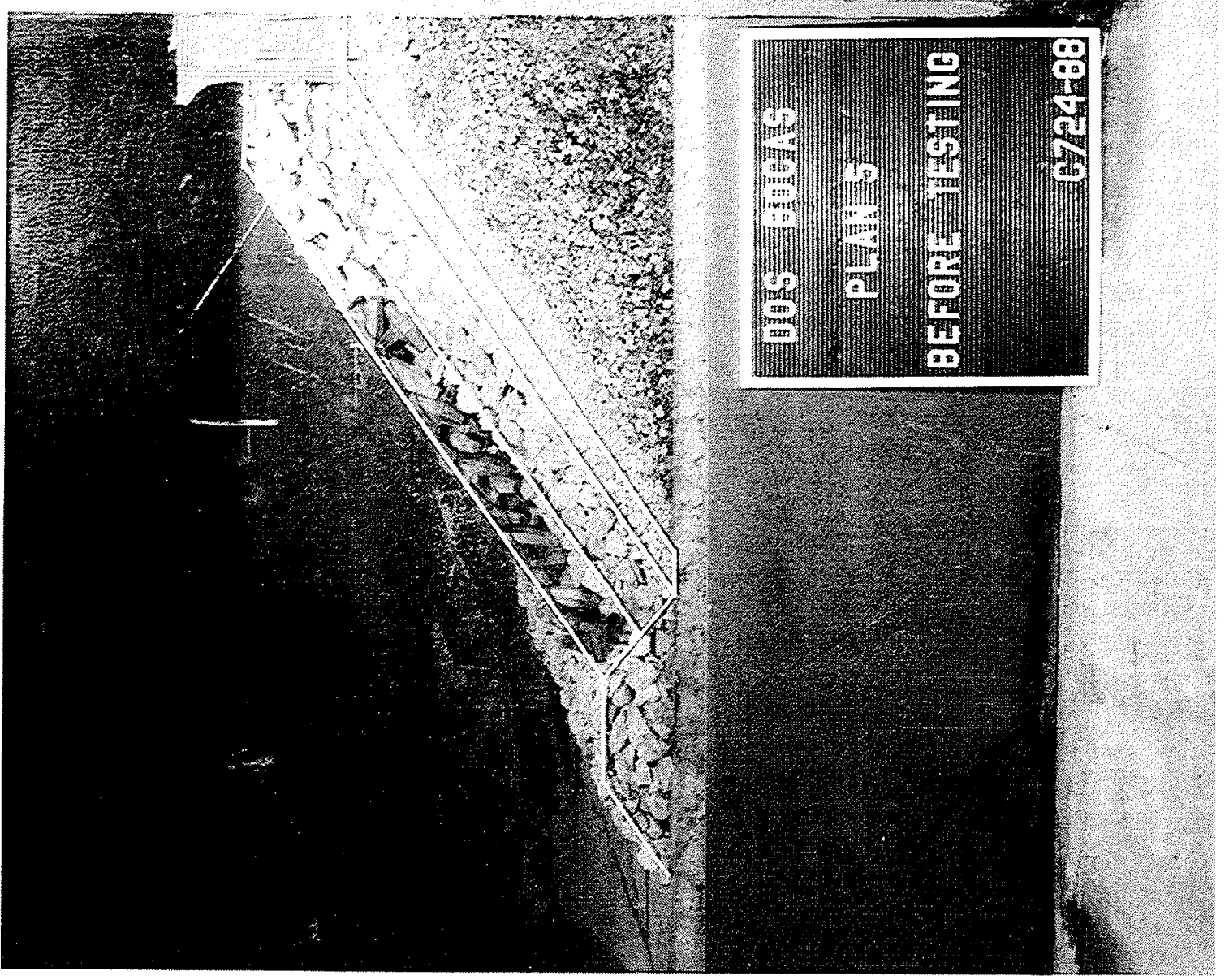

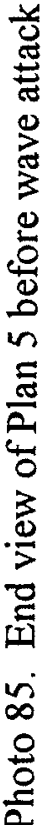




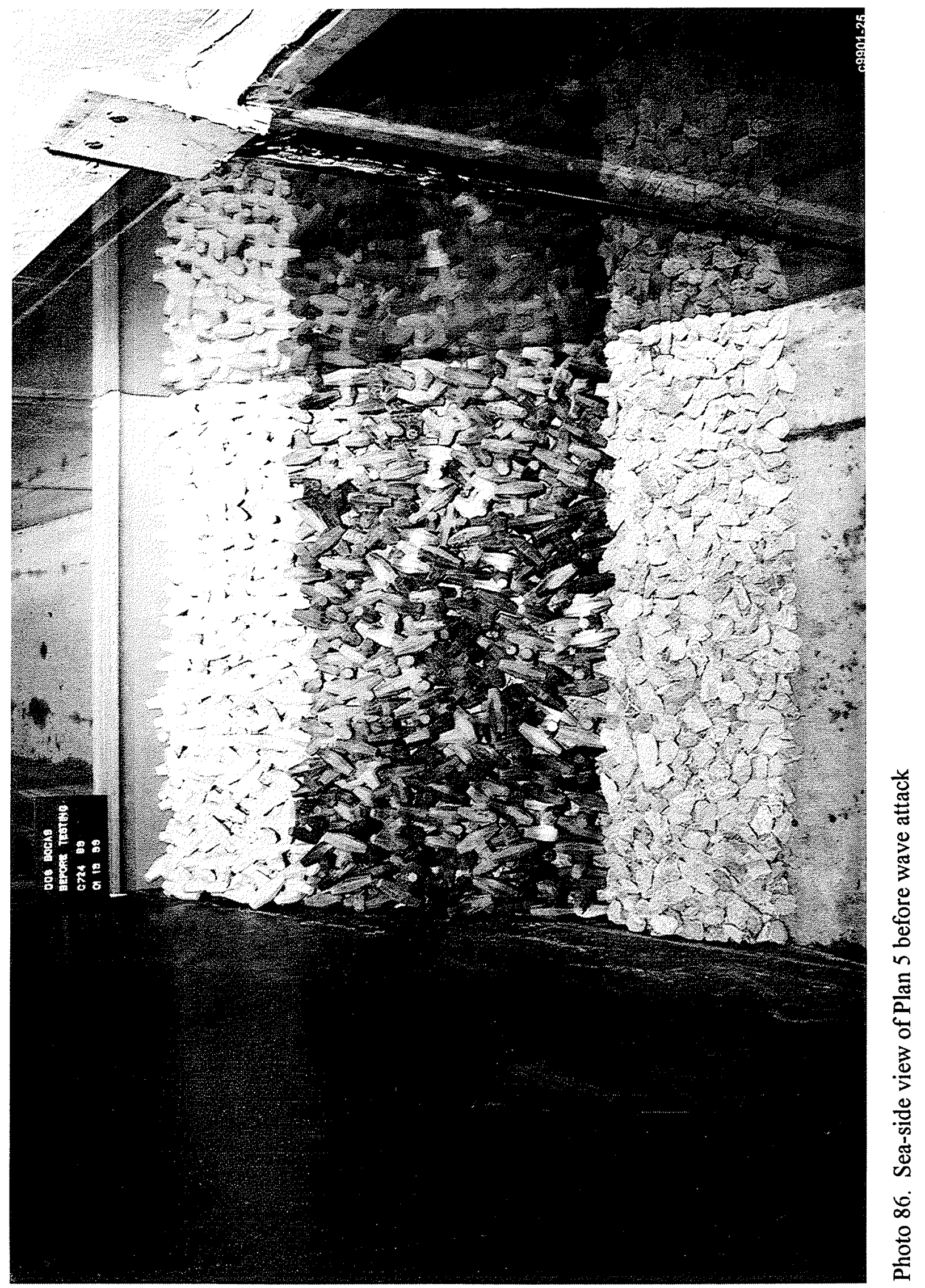




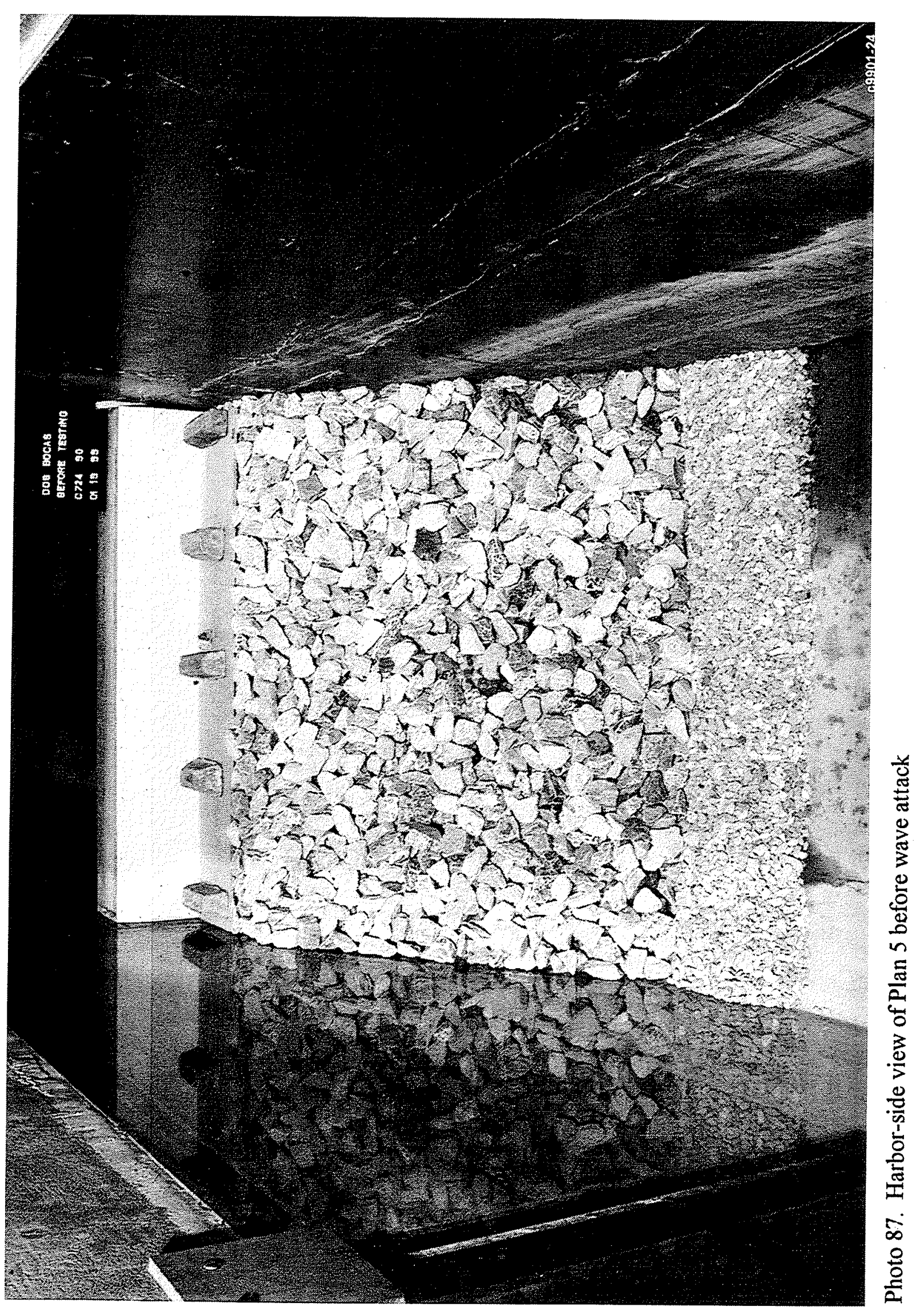




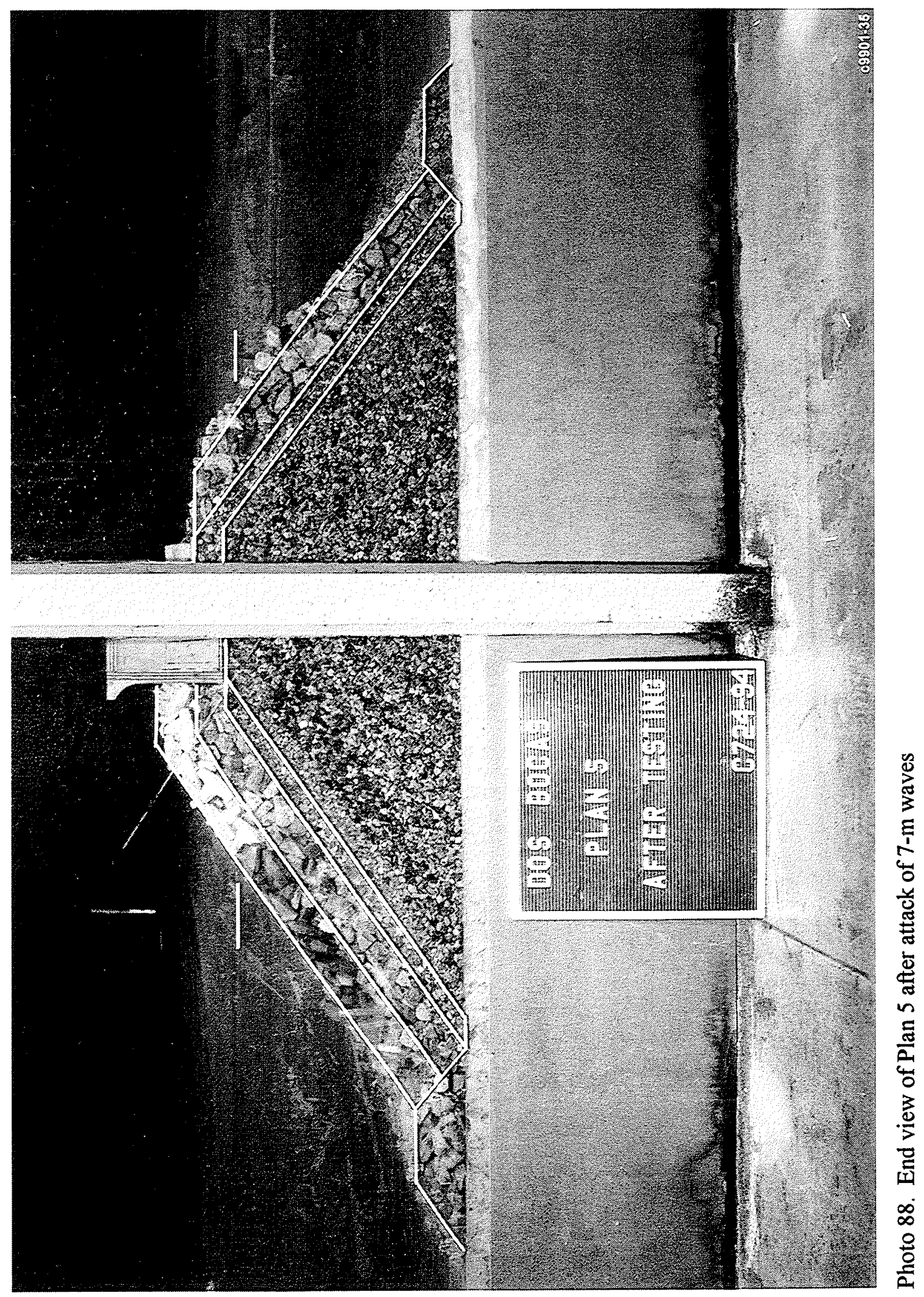




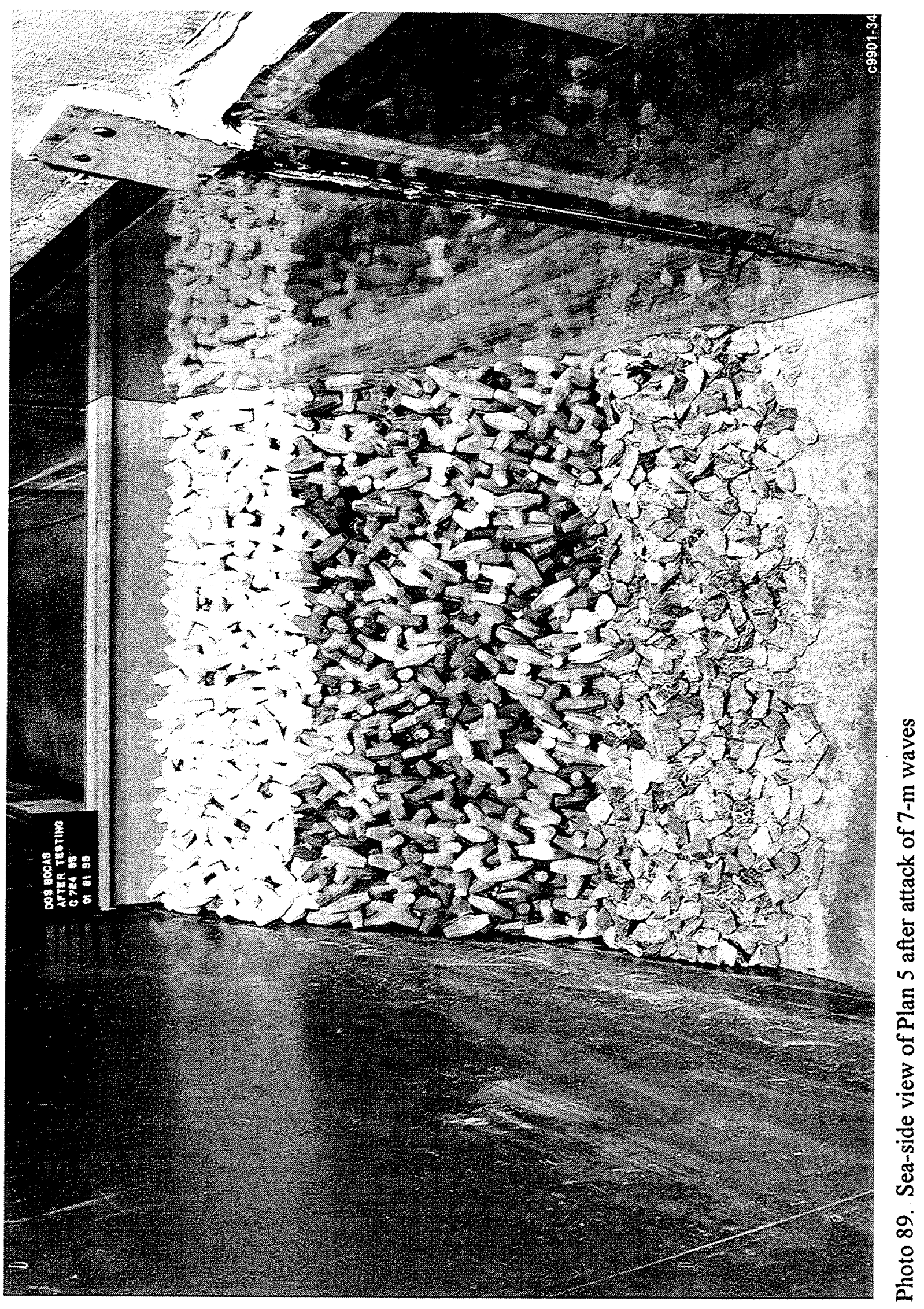




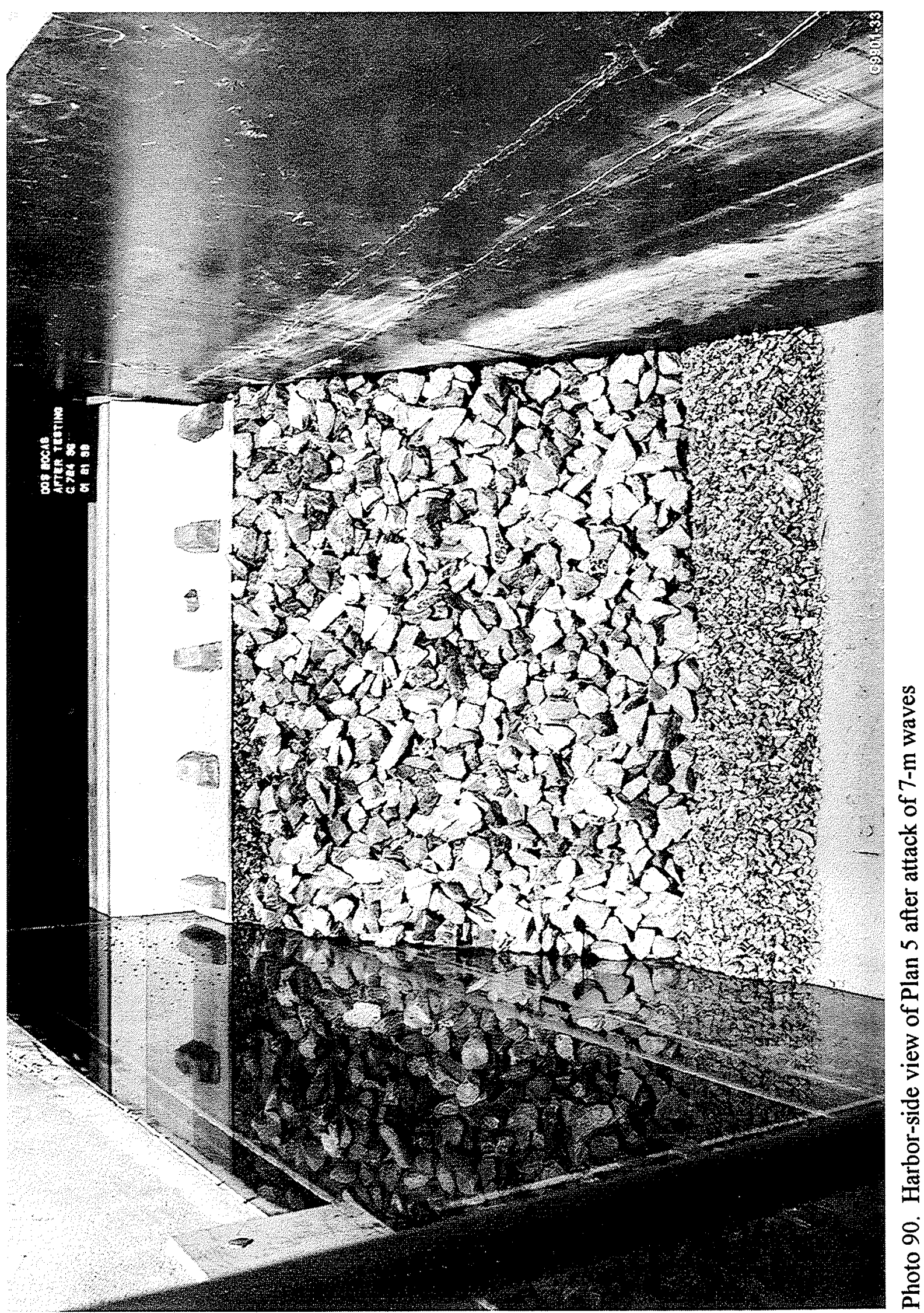



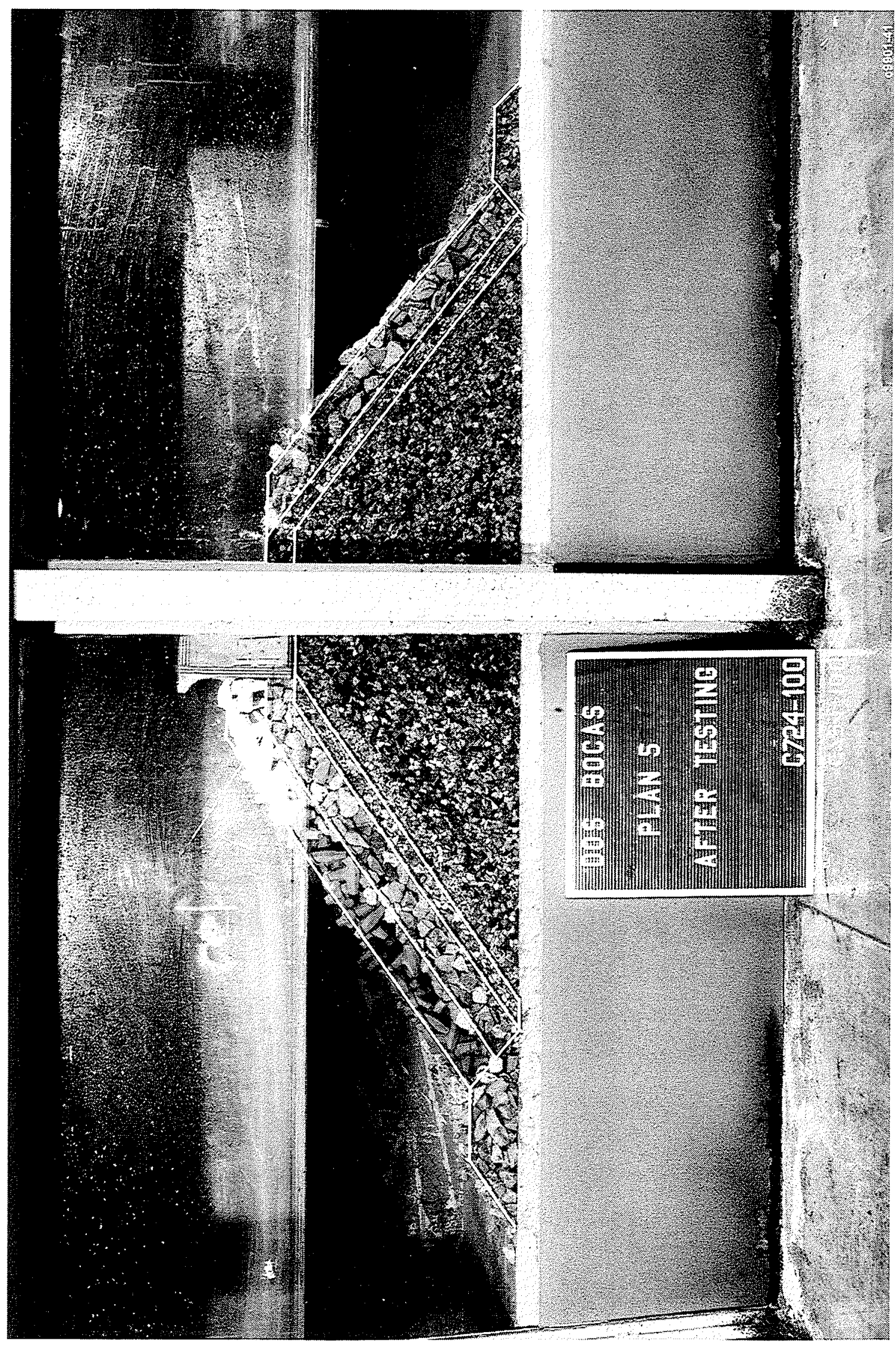

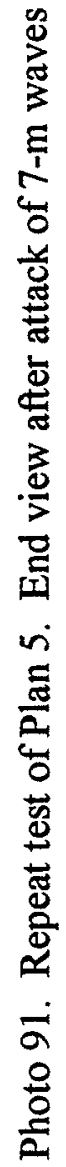




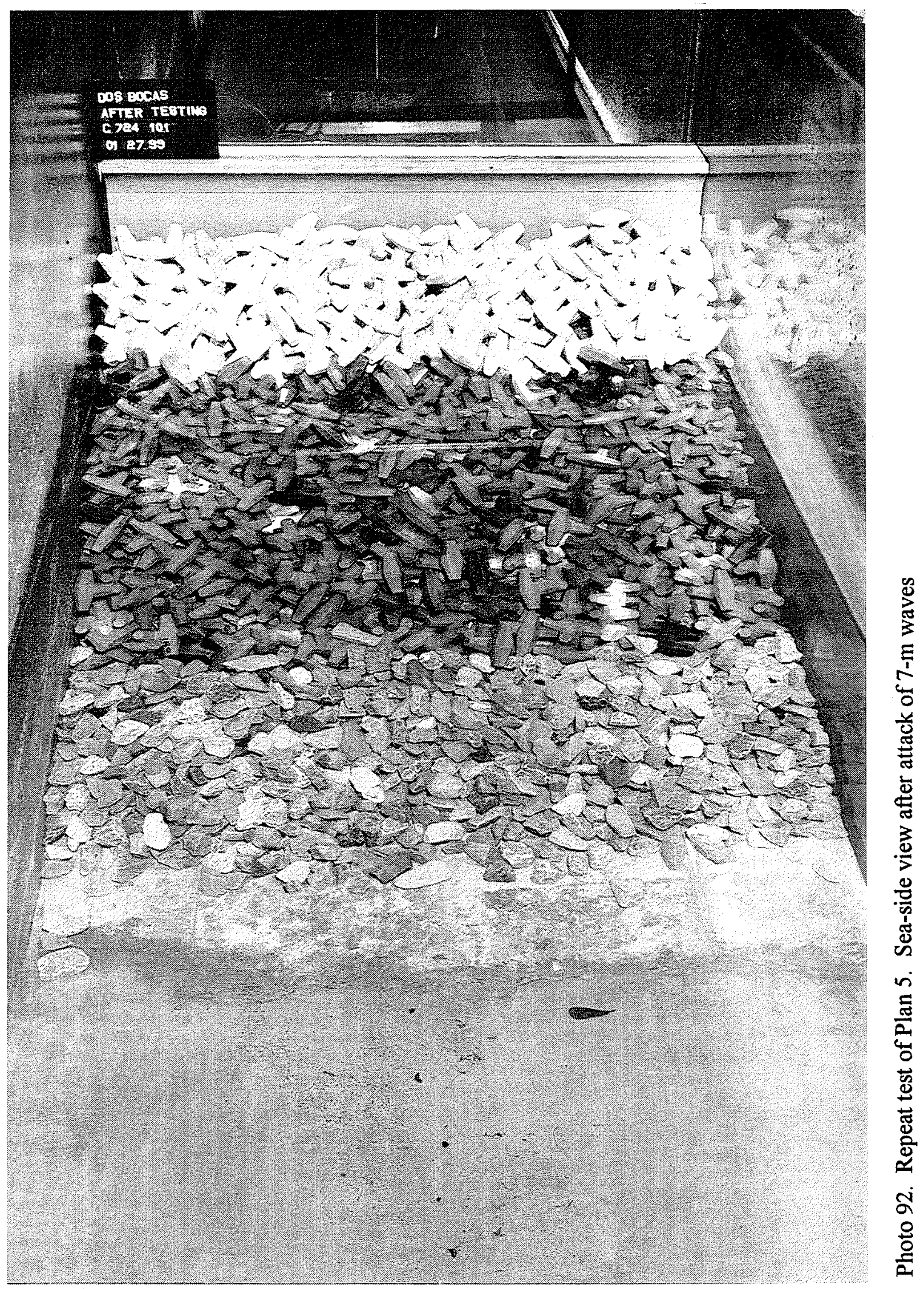




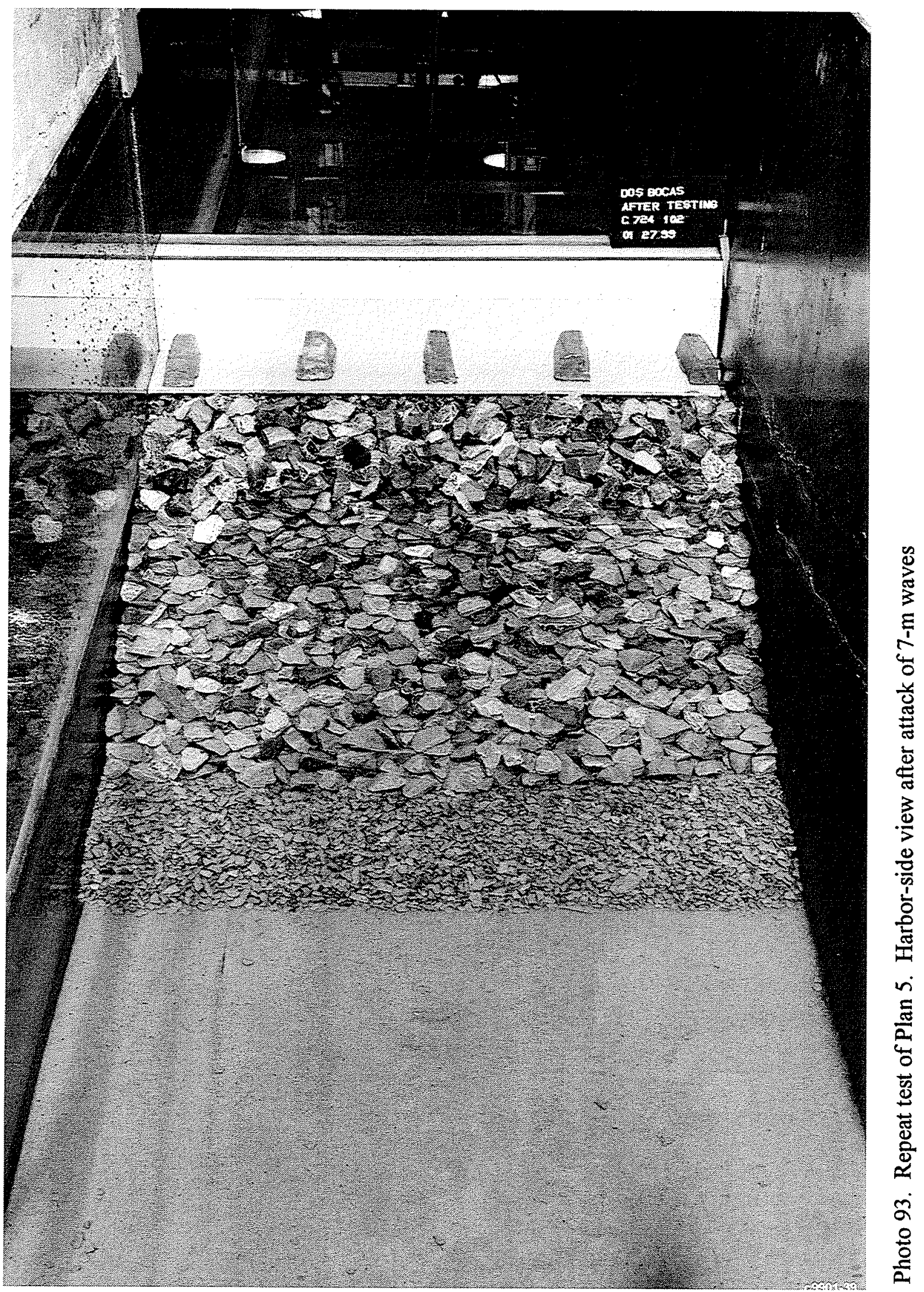



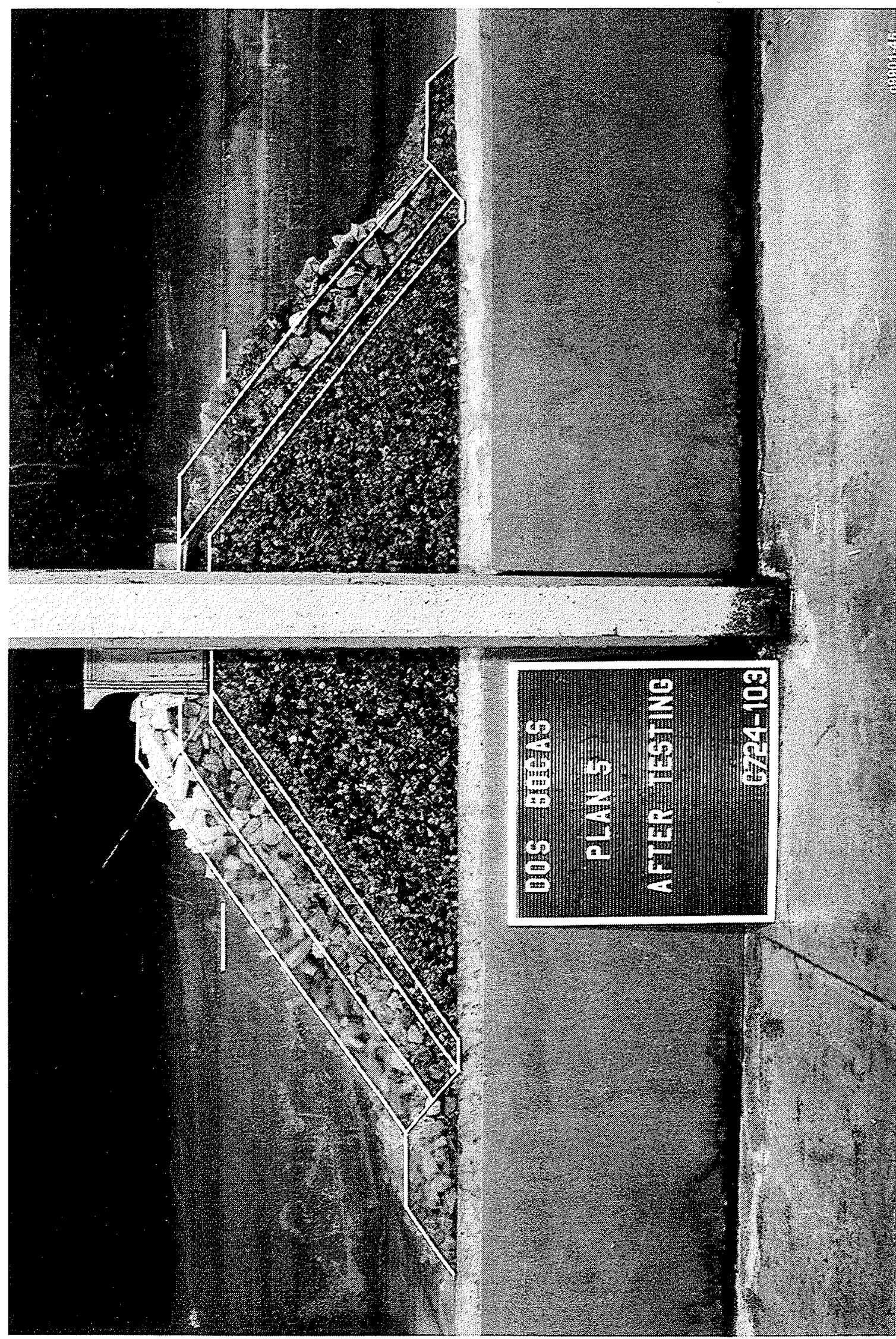

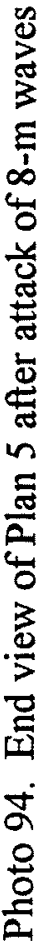




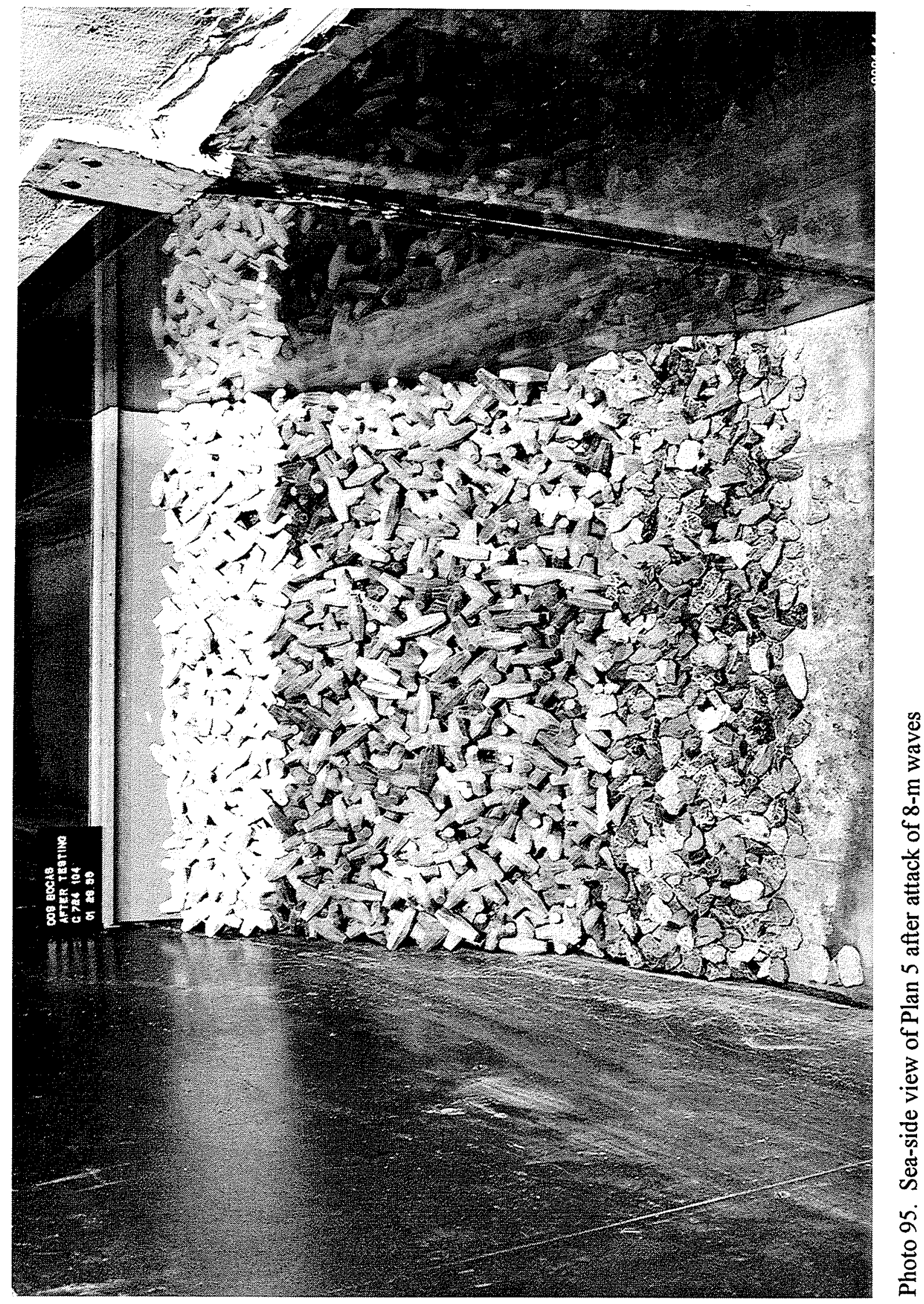




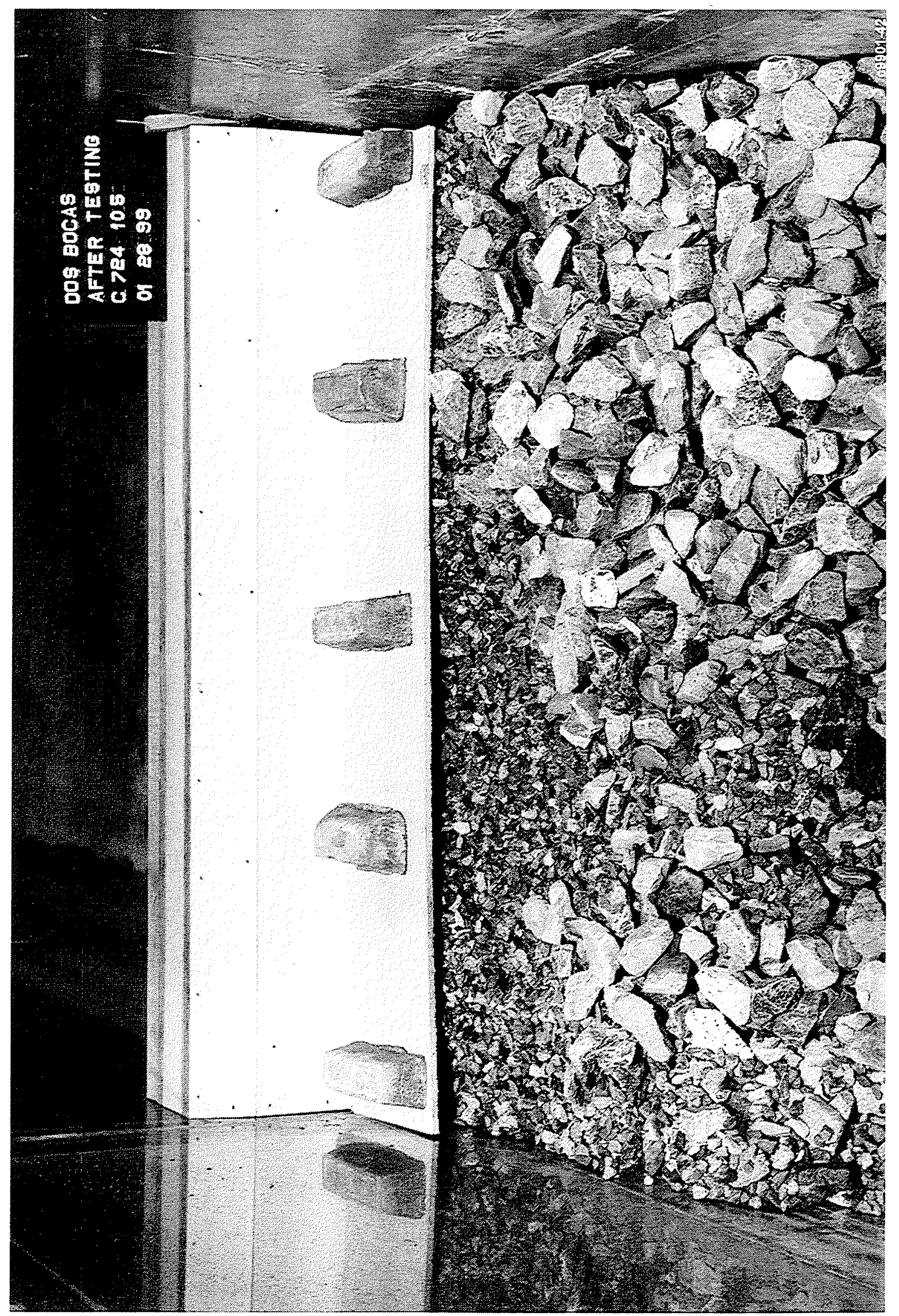

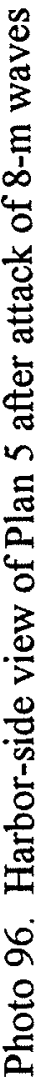




\section{REPORT DOCUMENTATION PAGE}

Public reporting burden for this collection of information is estimated to average 1 hour per response, including the time for reviewing instructions, searching existing data sources, gathering and maintaining the data needed, and completing and reviewing the collection of information. Send comments regarding this burden estimate or any other aspect of this collection of information, including suggestions for reducing this burden, to Washington Headquarters Services. Directorate for Information Operations and Reports, 1215 Jefferson Davis Highway, Suite 1204, Arlington, VA 22202-4302, and to the Office of Management and Budget, Paperwork Reduction Project (0704-0188), Washington, DC 20503.

\begin{tabular}{|l|l|l|l}
\hline 1. AGENCY USE ONLY (Leave blank) & $\begin{array}{l}\text { 2. REPORT DATE } \\
\text { July } 1999\end{array}$ & $\begin{array}{l}\text { 3. } \\
\text { REPORT TYPE AND DATES COVERED } \\
\text { Final report }\end{array}$
\end{tabular}

\begin{tabular}{|l|l|} 
4. TITLE AND SUBTITLE & 5. FUNDING NUMBERS
\end{tabular}

Rubble-Mound Breakwater Stability Tests for Dos Bocas Harbor, Tabasco,

Mexico

6. AUTHOR(S)

Robert D. Carver

7. PERFORMING ORGANIZATION NAME(S) AND ADDRESS(ES)

U.S. Army Engineer Waterways Experiment Station

3909 Halls Ferry Road, Vicksburg, MS 39180-6199
8. PERFORMING ORGANIZATION REPORT NUMBER

Technical Report CHL-99-15

9. SPONSORING/MONITORING AGENCY NAME(S) AND ADDRESS(ES)

10. SPONSORINGMONITORING

Preinversion and Desarrollo, S.A. de C.V. AGENCY REPORT NUMBER

Callejon Retama 30, D. F. 04010, Mexico;

PEMEX Refinación y Producción

Marino Nacional \#329, C. P. 11311, Mexico

11. SUPPLEMENTARY NOTES

Available from National Technical Information Service, 5285 Port Royal Road, Springfield, VA 22161.

12a. DISTRIBUTION/AVAILABILITY STATEMENT

12b. DISTRIBUTION CODE

Approved for public release; distribution is unlimited.

\section{ABSTRACT (Maximum 200 words)}

The Port of Dos Bocas is located on the Gulf Coast of Mexico within the State of Tabasco, several miles west of the Yucatan Peninsula. This site has been selected for development of an oil, industrial, and commercial port to be developed through the Mexican Oil Company (PEMEX). The initial purposes of the investigation were to determine, by two-dimensional flume tests, the stability response of three alternate armorings for the proposed breakwater and to evaluate overall performance relative to wave overtopping. Finally, based on results of the initial tests and economic considerations, the best armoring alternative would be selected, and a final recommended section would be developed and tested.

The first test sections consisting of 13-Mt Core-Locs in a water depth of $11 \mathrm{~m}$ and 15-Mt Core-Locs in a water depth of $15 \mathrm{~m}$ proved to be stable for significant wave heights up to $7 \mathrm{~m}$. These armor weights are recommended for prototype use. Also, the crownwall elevation of $+10.3 \mathrm{~m}$ should be adequate for significant wave heights up and including $7 \mathrm{~m}$.

\begin{tabular}{|c|c|c|c|}
\hline \multicolumn{4}{|c|}{ 14. SUBJECT TERMS } \\
\hline & Breakwater & \multicolumn{2}{|c|}{ Dos Bocas, Mexico } \\
\hline & Coastal models & \multicolumn{2}{|c|}{ Stability modeling } \\
\hline & Core-Loc & \multicolumn{2}{|c|}{ Wave overtopping } \\
\hline 17. & $\begin{array}{l}\text { SECURITY CLASSIFICATION } \\
\text { OF REPORT }\end{array}$ & & $\begin{array}{l}\text { SECURITY CLASSIFICATION } \\
\text { OF THIS PAGE }\end{array}$ \\
\hline & UNCLASSIFIED & & UNCLASSIFIED \\
\hline
\end{tabular}

NSN $7540-01-280-5500$
15. NUMBER OF PAGES

121

16. PRICE CODE

19. SECURTY CLASSIFICATION
OF ABSTRACT


